Historic, Archive Document

Do not assume content reflects current scientific knowledge, policies, or practices. 



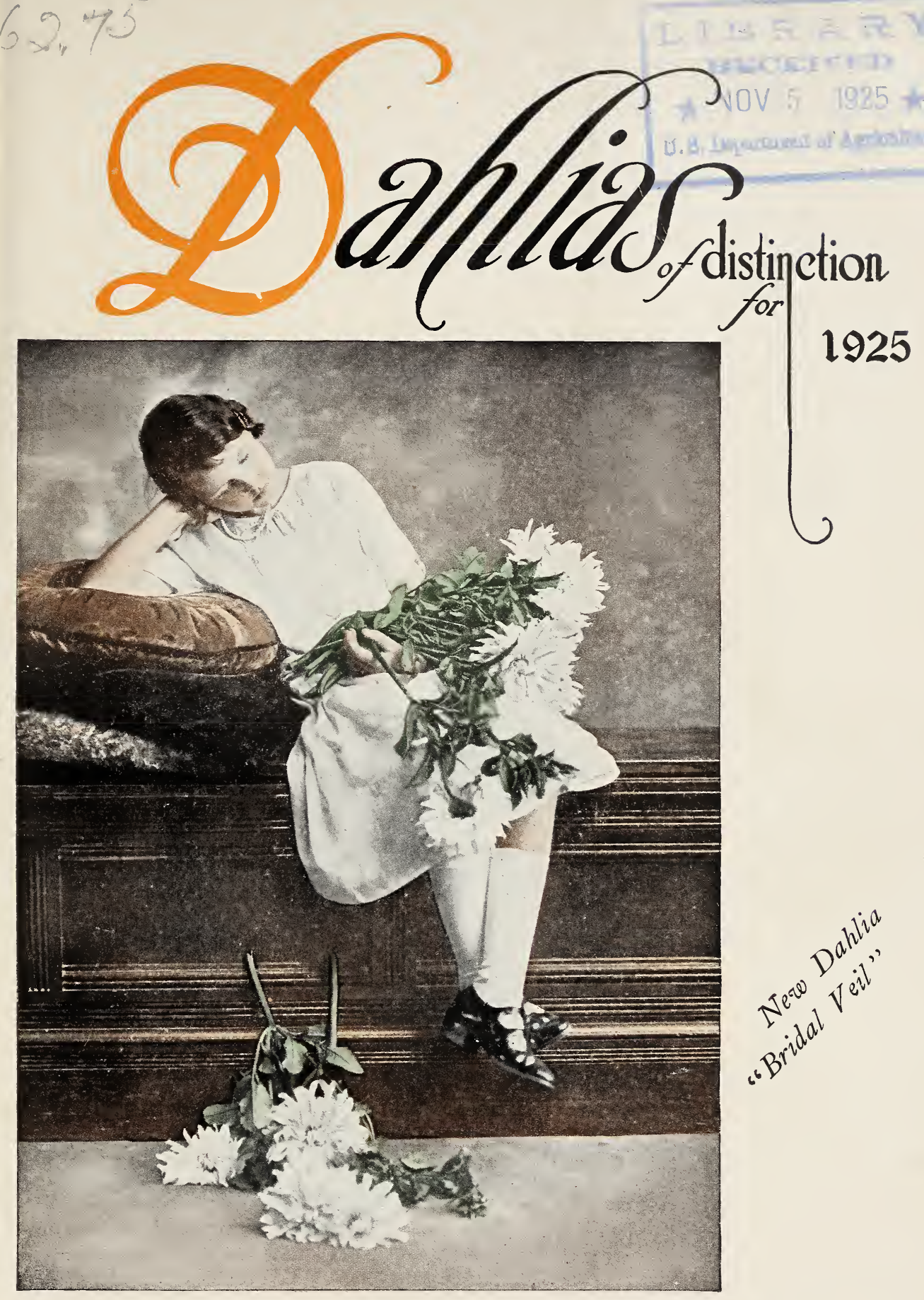

errown at
Westerly.
Rhode 90 sland 


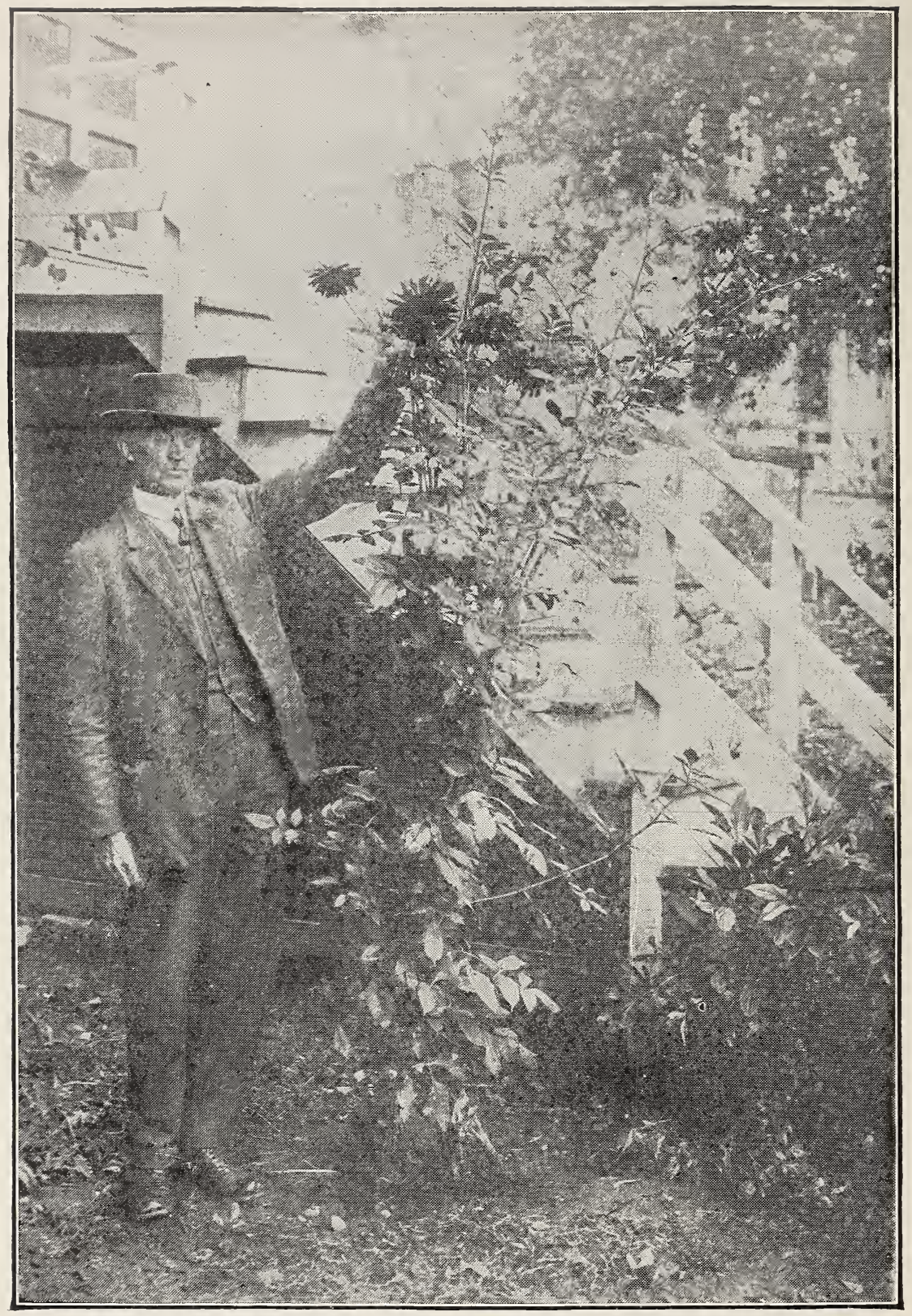

THE NEW CACTUS DAHLIA “GEO. L. STILLMAN" AND ITS ORIGINATOR

The accompanying illustration is from a photograph taken to demonstrate what the necessary quantity of water will do for a Dahlia in a dry time. After one flower had nearly opened on this plant it appeared to come to a standstill. Buds died, the foliage grew bushy, lacked a lively color, and no more buds appeared. I immediately pulled up a ridge of soil a little away from the plant, forming a reservoir that held two pails of water. The plant was then supplied with four or five ten-quart pails of water every third day until rain came.

When this photo was taken there were seven full flowers, two half open, and nine buds that showed the color of the flower more or less. Three of these flowers measured 7 inches in diameter and all the others over 5 inches.

Very few people realize the quantity of water needed to carry a Dahlia through a dry period. Not only does a Dahlia absorb the moisture, but the dry ground around also draws on the supply. 


\section{Trade discount, 1925, $331-3$ per cent tr.}

catalogue prices, except Head of the Nation, Lady Helen, and The U.S. A., which are net. It is necessary to order six of a kind to obtain this discount. On Groups figure on individual prices, not on group prices. No further discount on special offers. Discount on seed in packages 25 per cent; in bulk, price by the ounce upon application. 


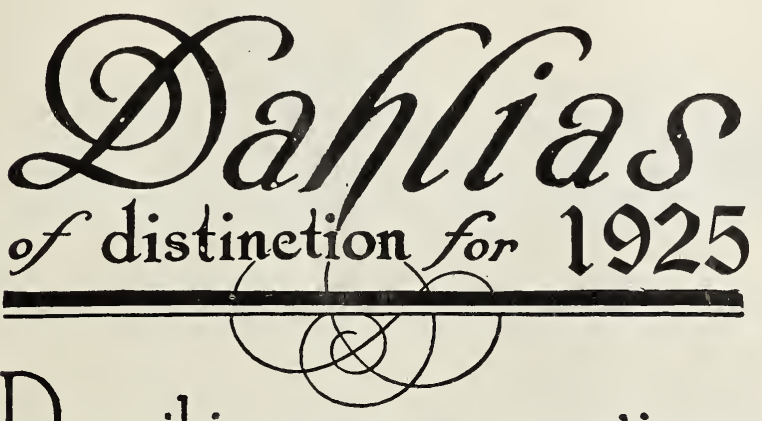

Describing my own creations, and standard varieties of all the different types, classes and colors of this flower.

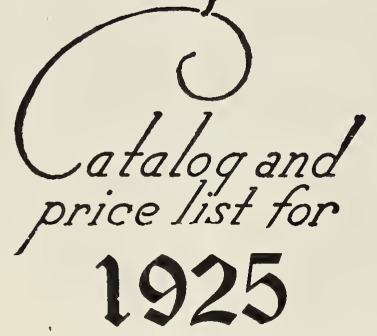

Ceorge Lefillman 


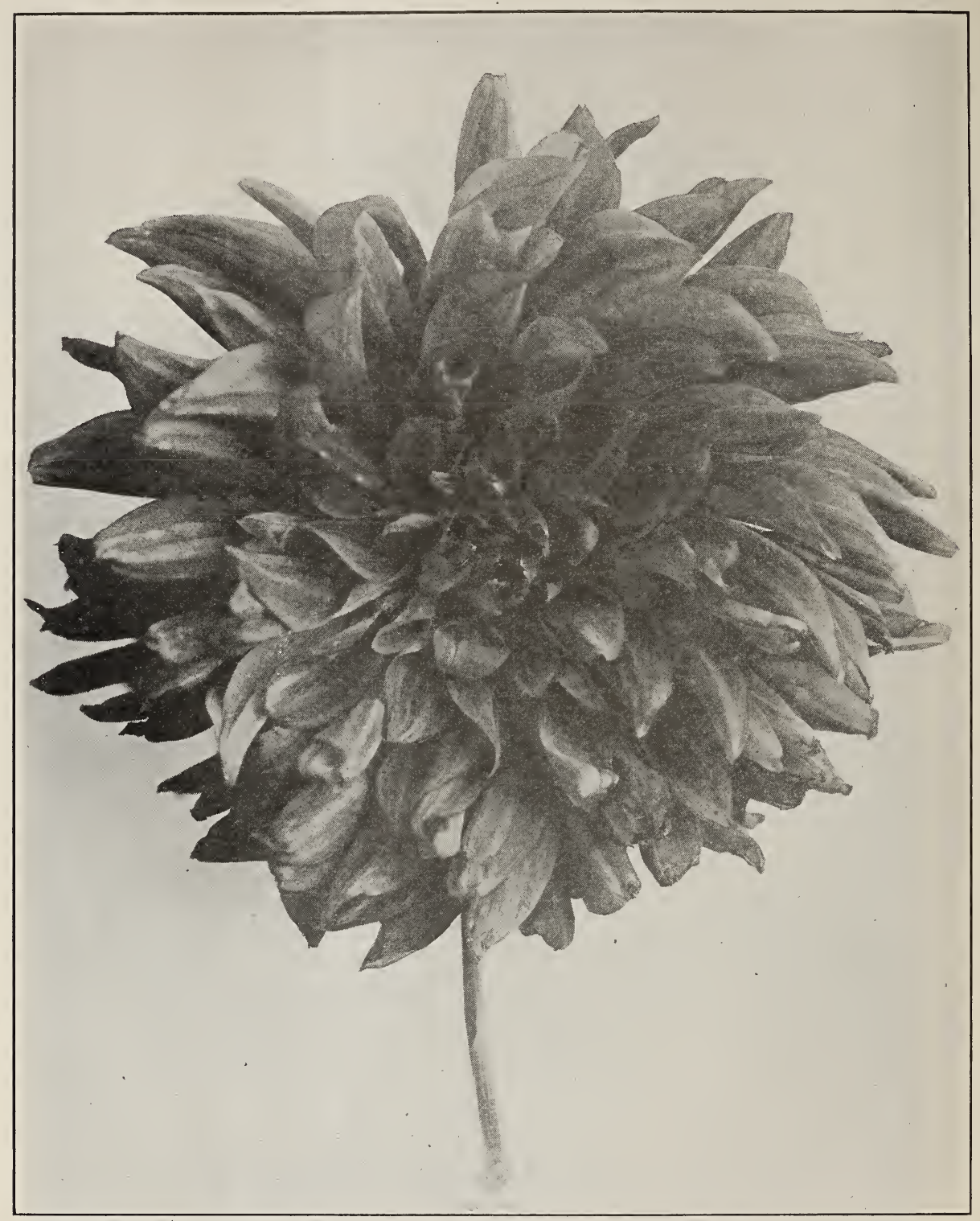

WORLD COURT

\section{The World Court, No. 2687 (Decorative)}

Color, canary yellow heavily clouded and striped with pink and fawn. The yellow shows more prominently in center of the dahlia. It possesses heavy, wide petals with a never failing center. A huge Hower on long stems. One of the dahlias without any disbudding or special care with four other blooms and a half dozen buds on the plant measured over 9 inches across. With disbudding the size is unlimited. 


\section{Greetings}

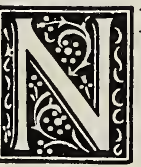

EVER has there been a time when I felt more like greeting my customers with a hearty hand shake, especially those with whom I deal each year. To know by repeat orders that my efforts to please them are satisfactory everytime they entrust their business to me-is indeed most gratifying. I think you, will all admit with me that all lovers of the dahlia who have room for only a half dozen bulbs as well as those who grow acres of them are of a more heart-to-heart family like disposition than those interested mainly in any other particular flower. We all take pride in our dahlia garden. We work in it cheerfully and happily; many times whistling and singing unconsciously as we study their ways and needs.

Do we not often stand as if in a trance looking at a new comer as it unfolds its inspiring array of colors? What other flower has stich attractions, such winning ways? It appears to know its mission, that of supplying beauty, charm, and unlimited pleasure.

The dahlia's admirers are increasing by leaps and bounds, and well they may. We who started growing the dahlia when very few people had ever seen or even heard of anything more than the common small flower, which was taken up in the fall in clumps, thrown into one corner of the cellar with a red rag around one clump, a pink one on another, and a white or yellow one on another, and so on; and in the spring planted again without dividing, can perhaps more appreciate the advancement in its beauty and size. With all the labor, study, and long hours of steady care which many of us have experienced, it has been a great source of life giving pleasure known only to those who have experienced it.

My main field has been a source of great attraction for thousands of tourists the past season. I wish here to emphasize the fact that my fields are always open for inspection and I cordially invite all whether already my customers or not to visit Westerly and my dahlia fields.

Visit Watch Hill, a popular summer resort only four miles distant, and one of the prettiest spots on earth.

GEO. L. STILLMAN.

Have you the real race begun?

The prize is not yours till won.

\section{REGARDING NEW YORK OFFICE}

The building in which my New York Office has been located is being remodeled. This fact compels me to discontinue it. Until further notice I will meet my customers in New York by appointment. 


\section{CLASSIFICATION OF DAHLIAS}

\section{AS ADOPTED BY THE AMERICAN DAHLIA SOCIETY}

Cactus Dahlia. a. True, fluted type. Flowers fully double; floral rays (petals) long, narrow, incurved or twisted, with sharp, divided, or fluted points with revolute (rolled back) margins, forming, in the outer florets, a more or less perfect tube for more than half the length of the ray.

b. Hybrid cactus or semi-cactus type: Flowers fully double; floral rays short as compared with previous type, broad, flat, recurved or twisted, not sharply pointed except when tips are divided (staghorn), margins only slightly revolute, and tubes of outer florets, if any, less than half the length of the ray.

Decorative Dahlias. Double flowers, full to center in early season, flat rather than ball-shaped, with broad, flat, somewhat loosely arranged floral rays with broad points or rounded tips which are straight or decurved (turned down or back), not incurved, and with margins revolute if rolled at a11.

Ball-Shaped, Double Dahlias. a. Show type: Double flowers, globular or ballshaped rather than broad or flat, full to center, showing regular spiral arrangement of florets; floral rays more or less quilled or with markedly involute margins and rounded tips.

(The class called Fancy Dahlias is not recognized separately in this classification, but is included in the sub-section A.) b. Hybrid show, giant show or colossa' type: Flowers fully double, broadly hemispherical to flatly globular in form, loosely built so spiral arrangements of florets is not immediately evident; floral rays broad, heavy, cupped or quilled, with rounded tips and involute margins.

c. Pompom type: Shape and color may be same as $A$ or $B$; but must be under two inches in diameter.

Paeony-flowered, or "Art" Dahlias. Semi-double flowers with open center, the inner floral rays being usually curled or twisted, the other or outer petals being either flat or more or less irregular.

Duplex Dahlias. Semi-double flowers, with center almost exposed on opening of bud, with petals in more than one row, more than 12, long and flat, or broad and rounded, not noticeably twisted or curled. Many socalled Pæony-flowered Dahlias belong here.

Single Dahlias. Open centered Dahlias, small to very large, with 8 to 12 floral rays, more or less in one circle, margins often decurved (turned down or back). There are no distinctions as to colors. The type embraces the large Twentieth Century, as well as small English varieties.

Collarette Dahlias. Single type: Open centered blossoms with not more than nine floral rays with one or more smaller rays, usually of a different color, from heart of each ray floret, making a collar about the disc.

\section{GENERAL INSTRUCTIONS}

\section{IT IS IMPORTANT THAT YOU READ THESE CAREFULLY! ORDER EARLY}

First of All.-Send me your order as soon as you receive my catalogue, as the demand for some varieties often exceeds the supply, and those who order early are less liable to disappointment than if they waited till the rush at the time of planting. ORDER bulbs sent early to avoid disappointment. Kindly order by name and not by number.

If you do not want to spare all of the money to send with the order, send the order along, together with one-quarter of the amount as a guarantee of good faith, and the balance can be remitted when you receive notice that your order is ready to ship.

Customers who are not personally known to me will be notified when to remit the amount of their bill.

Bulbs are shipped as soon after April 1st as convenient, unless otherwise specified.

When sending orders use the Order Blank furnished with this catalogue. Any number of additional Order Blanks may be had upon application. When filling out the Order Blanks, be sure to fill out the Second Choice columns as well as the First Choice.

It is well to mention the varieties that you are willing to have substituted in case some of those selected are all sold out. Or, if requested, I will select such varieties as will substitute to best advantage. Otherwise, money sent for such bulbs will be returned to the sender.

Size of Bulbs.-Some varieties of Dahlias always produce very small bulbs (or tubers), while other varieties make large ones. So do not consider small bulbs as worthless, for they are equally as good as large ones.

I Guarantee Every Bulb I Sell.-The utmost care is always exercised in selecting every bulb I send out, and every one is believed to have at least one good sprouting eye that will produce a good plant under proper care, or replace it with another. 


\section{GENERAL INSTRUCTIONS-Continued}

Bulbs to be replaced after July 1st will be booked for shipment the next season only, and in all cases the bulbs to be replaced must be retuined.

I guarantee all bulbs to be true to name and sure to grow at the time they are sent out.

The best way to send money is by registered letter, money order or express order.

Do not hestitate to send small orders. An order for one bulb will be as carefully filled as an order for one thousand.

Terms.-Cash invariably in advance, or C. O. D. On all retail orders fully paid for in advance I will prepay carriage to any part of the United States. This does not apply to special collections.
ATTENTION.-Orders taken in the Fall not fully paid for will be sent C. O. D., unless previous arrangement has been made.

Do not delay ordering until the time to plant, as many varieties may be sold out before that time. ORDER EARLY.

If bulbs are received before it is convenient to plant them, they should be covered with moist earth until planted.

I use the utmost care to prevent errors in labeling and packing, but if an error does occur, kindly notify me, that it may be rectified immediately.

Please bear in mind that orders are booked and assembled in rotation as received, and are packed to be shipped at the time your order specifies.

Address all orders and communications to Geo.' L. Stillman, Dahlia Specialist, Westerly, Rhode Island. Important. - It is essential that you use the initial "L." as there are several Geo. Stillmans in town.

\section{LOCATION OF GARDENS}

No. 1-25 Granite Street (Residence). No. 2-Stillholme (Farm), Ashaway Road. No. 3-(Main field), Watch Hill Road, opposite Cemetery. No. $4-20$ Newton Avenue, Office and shipping dept.

Do not hestitate about ordering Dahlia Bulbs on account of distance, for they go safely by mail or express to any part of the world

\section{You should notify me if you change your address, as the postmaster will not forward catalogues 'without extra" postage."}

\section{POINTERS ON GROWING DAHLIAS}

There are always some people who do not succeed in growing Dahlias with their first season's experience, and are naturally very much disappointed. To those I wish to say that it is not due to a fault of mine or of the bulbs, but is wholly due to your method of cultivation, kind of soil, or weather conditions. A glance through the hundreds of letters I receive from pleased, enthusiastic people who purchase their stock from me is positive proof that my stock is without fault. Exercise a little patience and a whole lot of good common sense and you will grow as nice Dahlias as anyone.

The Right Kind of Soil.-The kind of soil for Dahlias is a light loam or a stony knoll or side hill.

It is very essential that the soil has good drainage. A rich soil is all right if it has good drainage. Heavy, solid ground will produce an abundance of foliage and few and inferior blossoms.

It should be borne in mind that the poorer the soil, the more fertilizer it requires, and the lighter the soil, the more water it needs. See directions for watering elsewhere. It is a very unwise thing to advise no fertilizer in growing Dahlias, especially in the Eastern states. As a rule nothing will grow without sufficient nourishment. Heavy soil is usually quite rich and when lightened as directed elsewhere, will not need as muçh fertilizing as weak, light soil.
Heavy Soil.-If your soil is heavy with a clay sub-soil, it should be lightened with coal ashes or sand. If coal ashes are used, the coarser that they are the better, the main object being to make the soil lighter, more porous, and to give it a good drainage. I have seen Dahlias grown to perfection on a spot where the soil was nearly clear coal ashes.

In applying coal ashes they should be plowed, or spaded in, broad cast, 10 to 18 inches deep, and not dumped in one spot where the Dahlia is planted. One part coal ashes, or sand, and one part soil will not lighten it any too much. This will give a better drainage and allow the sun to act on the soil to a greater depth.

Ashes from either hard or soft coal will do but on very heavy soil those from soft coal 


\section{POINTERS ON GROWING DAHLIAS-Continued}

are preferable, being much coarser. Both kinds mixed together are also desirable.

Watering.-Watering is one of the most essential things in producing perfect blooms on your Dahlias. 90 per cent. of the failures in growing Dahlias is due to lack of water when the hot days of Summer come. Did you ever notice that the stalk of the Dahlia is about all water except the outside shell, and that where sufficient water is supplied the hole in the center of the main stalk is nearly full of water?

The Dahlia, as soon as it begins to bloom, will absorb the moisture from the soil for a distance of two or three feet. For example: Dig down deeply amid the roots of the Dahlia and then again about 4 or 5 feet from the plant and observe the difference. The dry hot days come earlier some years than others, but usually when the buds begin to open it is time to begin watering.

The best method of doing this is to make a basin-shaped mound of earth around the plant, about 2 feet in diameter, and into this basin turn three or four water pails full of water as often as every three or four days. Fertilizer is used to obtain size, water to make richness of color and perfection. Try it.

Planting.-The ground should be plowed or spaded to a depth of 8 to 10 inches. Make the drill to receive the bulb, 12 to 16 inches long and 6 inches deep, and about 6 inches wide. Lay the bulb down flat in the drill and then apply the fertilizer on both sides of the bulb, 4 to 6 inches from the bulb.. If pulverized Sheep Manure is used, about one pint to one quart is usually sufficient to each bulb according to the strength of the soil. If poultry manure is used one pint to each plant is sufficient.

It is very desirable to plow in a quantity of stable manure broadcast. Always stick the stake in the ground before covering the bulb and thus avoid piercing any part of the bulb.

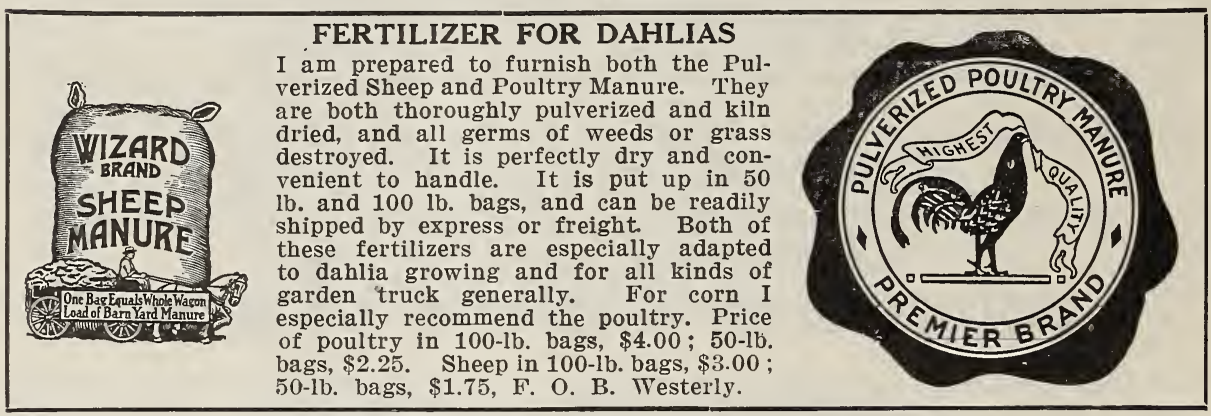

\section{A TALK FOR THE BEGINNER \\ A FEW THINGS THAT SHOULD BE CONSIDERED}

Do not expect to grow as large flowers as an expert the first year that you try Dahlias, for with any flower you need some experience as well as instruction in order to have great success.

One of my customers said that he had no luck with Dahlias until he read my catalogue. There he found the very information that he needed, viz.: How to lighten the soil and render it porous.

If you have a heavy growth of plants and no flowers it is an indication of too heavy soil, or the same result will be encountered on some dry, rich land. In the latter case water is what is needed and in great abundance, say three or four pails of water three times a week to each plant, with some liquid fertilizer once a week.

Notice that after a heavy rainfall Dahlias take on a new life and the flowers are fuller in the center and more brilliant in color.

All the Dahlias described in this catalogue as to color and shape are described to the best of my ability, but I do not guarantee them to fully meet the ideas of all purchasers in regard to color shadings.

\section{NEVER STAND THE BULB ON END WHEN PLANTING}

The best method of planting in the field is to make the distance between every other row 3 and 5 feet, respectively, thus affording a passageway on one side of each row after the plant will become large and fill the 3 -foot space. $2 \frac{1}{2}$ to 3 feet apart in the row accord- ing to the nature of the plant is about the right distance when 3 - and 5 -foot spaces are used. Do not plant near trees or shrubs, as tree roots will take the strength of the soil from the Dahlia. In the open by themselves is the best place. Avoid the south side of a 


\section{POINTERS ON GROWING DAHLIAS-Continued}

large building where the sun is extremely hot without a good circulation of air, for the flowers will burn on the back before fully open.

For early flowering they may be planted any time after May 1st or as soon as all danger from frost is passed.

Some people have an idea that the larger the bulb the better the plant it will make, but this is not the case. A. small bulb is just as good as, and in many cases better than, a large one.

The Clumps should be divided about the time that you are to plant in the Spring. At this time you can readily see where the sprouts are and with the use of a knife the head of the clump can be split through between the sprouts, or eyes, taking whatever bulb, or bulbs, would come off with one sprout. One sprout is always better then more. If the sprouts are over 2 inches long when you plant the bulb it is better to cut them off a half-inch from the bulb and a new sprout will come and make a better one than the slender one that grew in the cellar.

Care of the Plants.-Keep the ground weil cultivated and free from weeds. A frequent stirring of the surface is very beneficial. An application of some standard fertilizer raked into the surface of the soil around the plants two or three times during the season will be very helpful to the development of the flowers.

Never leave more than one or two stalks in a hill. You will have better plants and larger flowers if you will allow only one sprout to grow.
When the buds begin to. open a dressing of liquid fertilizer around the plants, several times in a season, will also be beneficial.

Stakes may be used to advantage to prevent plants from breaking down.

Disbudding.- The proper way to disbud the plants is as follows: If the first, or crown bud, appears to be weak or defective, cut it off.

Then when flowers appear on branches, cut them for decorative purposes, below one or two joints, thus removing with the flower whatever buds and foliage may be there. The flowers and foliage cut thus give a better effect for whatever purpose they are to be used. This method is a good invigorator for the plant and at the same time does all the disbudding required on the majority of Dahlias.

Remember, if bulbs are received before you are ready to plant them, cover them with moist earth to keep them from drying up.

Care of the Bulbs in Winter.-After the frost has killed the foliage, lift the clumps with a spade fork and allow them to dry in the sun about half a day. They should then be stored in a place free from frost. If an old-style cellar without cement bottom or heat, they need not be covered, but if cemented and heated by furnace, they should be covered with papers and cloth to keep the air from them and thus prevent too much shriveling.

On the following pages will be found the 1925 prices for divided field-grown roots.

9 MAN that's clean iniside and outside; who neither looks up to the rich nor down on the poor; who can lose without squealing; who can win without bragging; considerate to women, children, and old people; who is too brave to lie, too generous to cheat, and too sensible to loaf; who takes his share of the world's goods and lets other people have theirs-this is the ideal conception of a true gentleman. 


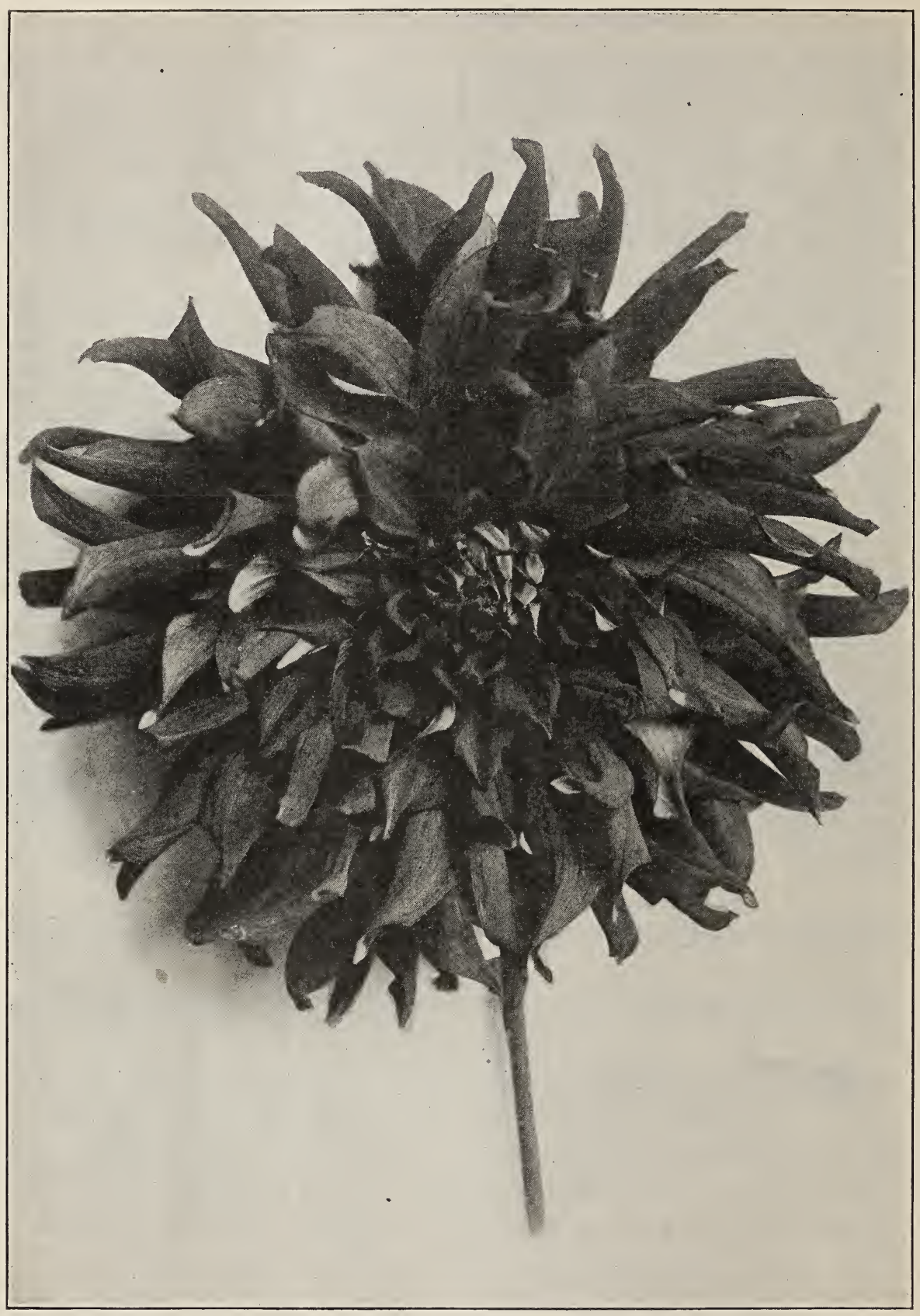

HEAD OF THE NATION 


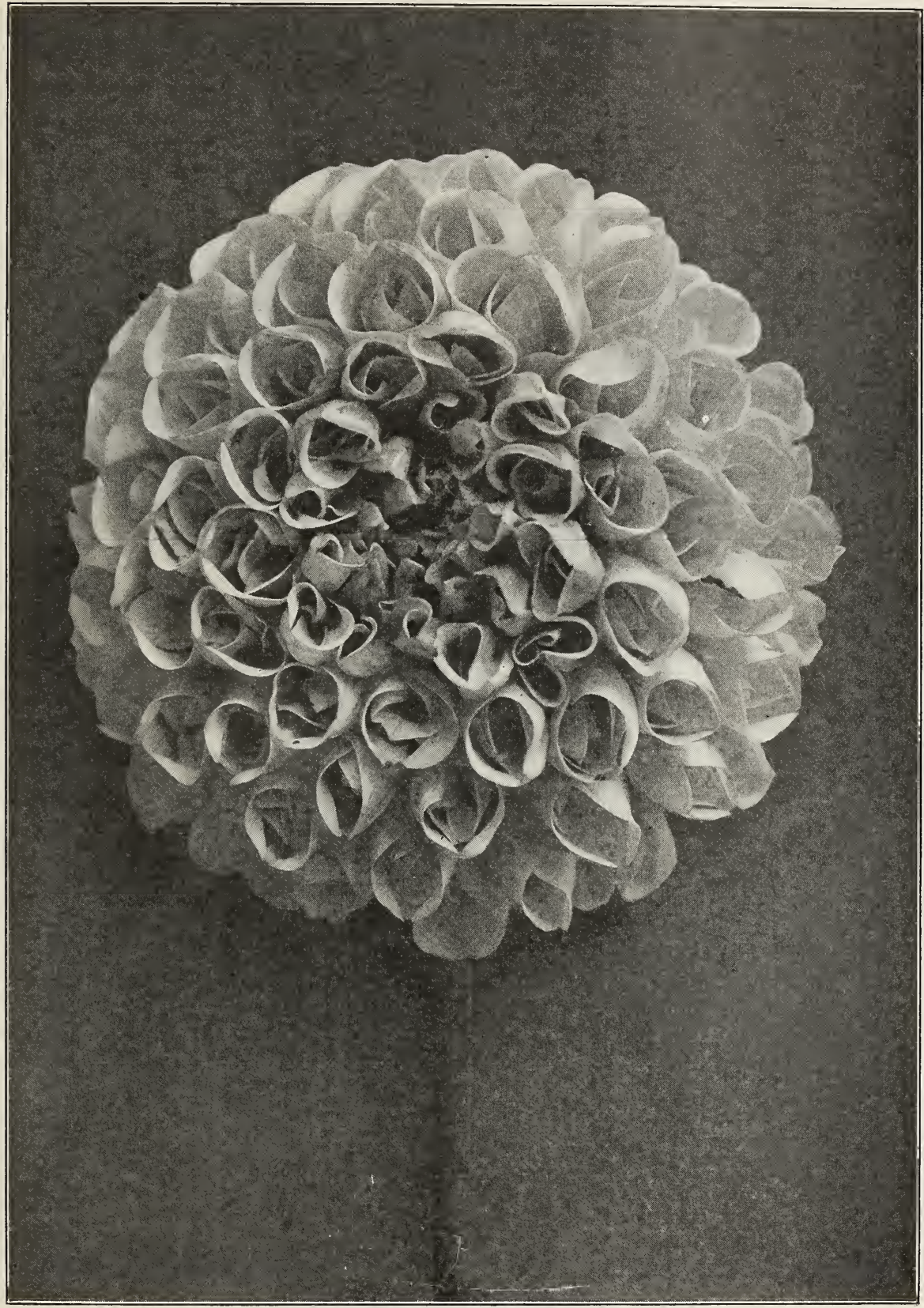




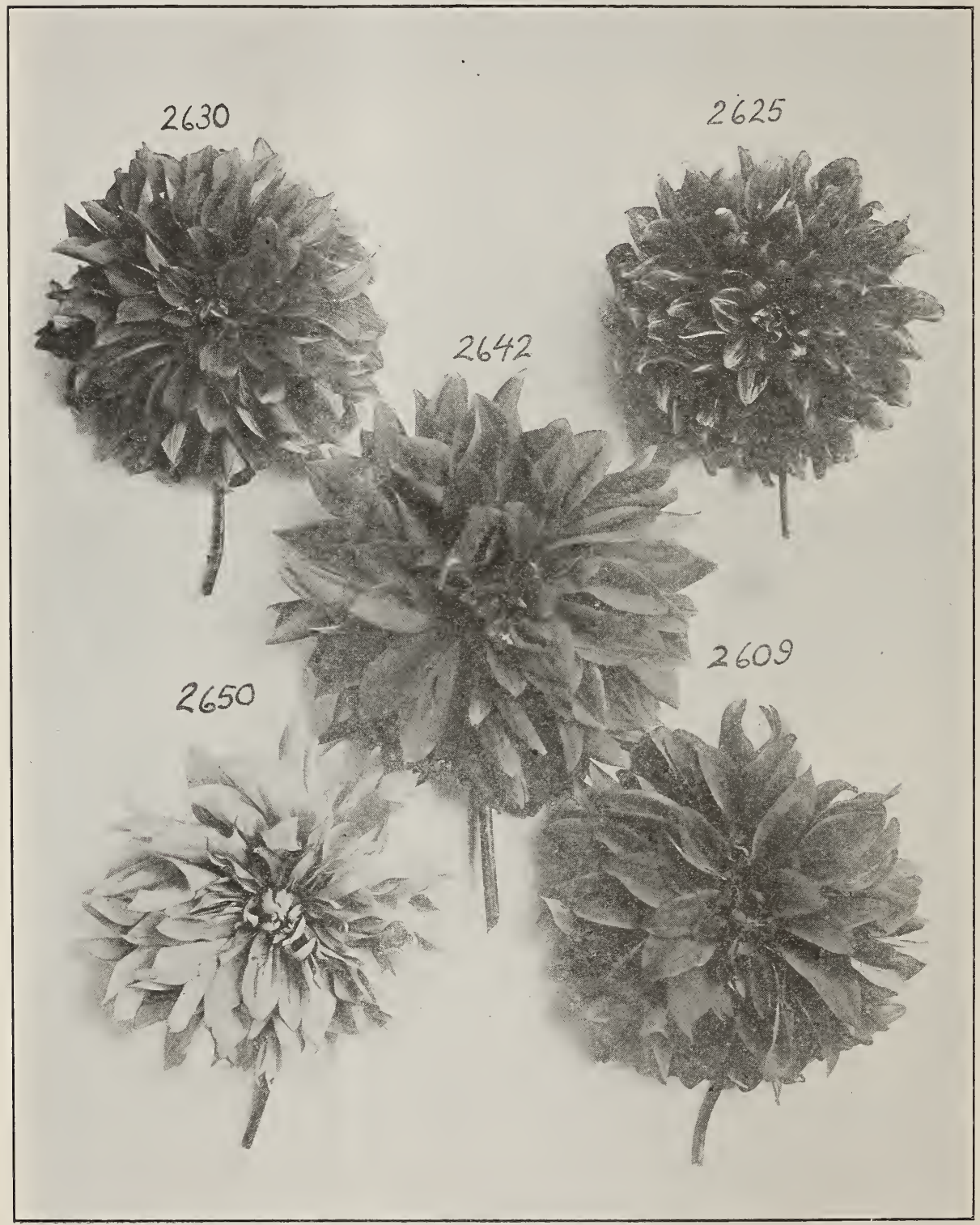

The Famous Rhode Island Group 


\section{THE FAMOUS RHODE ISLAND GROUP THE NEW GROUP OF FIVE FOR 1925}

\section{William Ellery, Decorative, No. 2625}

Color, a beautiful cerise carmine red. A large flower with a fine center which is wonderfully attractive both in size and color.

Price, $\$ \mathbf{2 5 . 0 0}$

\section{Stephen Hopkins, Decorative, No. 2630}

Color a bright, rich, reddish salmon. A huge dahlia of a beautiful color and formation. This flower is a prize in any garden.

Price, $\$ 25.00$

\section{Gilbert Stuart, Paeony, No. 2650}

Color, deep lilac with veins of deeper lilac running through the florets. A beautiful color and a monster in size. This dahlia is a very unusual one in color, form, and size.

Price, $\$ \mathbf{2 5 . 0 0}$

\section{Commodore Perry, Decorative, No. 2642}

Color, pure clear canary yellow. One of the largest decorative dahlias in existence, measuring over Io inches as grown naturally in my trial field without any disbudding whatever or extra care. A monster flower with a fine form.

Price, $\$ 25.00$

\section{Nathaniel Greene, Decorative, No. 2609}

Color, medium yellow with outer petals heavily veined salmon. A beautiful large flower of good substance.

Price, $\$ 25.00$

NOTE:

NATHANIEL GREENE was a famous general "in the Revolutionary War; a personal friend of Washington and second to him in military affairs.

GILBERT STUART was a famous artist. His famous painting of Washington and many other prominent people is familiar history.

STEPHEN HOPKINS and WILIIAM ELLERY both signed the Declaration of Independence from Rhode Island.

COMMODORE OLIVER HAZARD PERRY was the hero of the battle of Lake Erie in 1813.

But stern Rhode Island's early need

Had more than rock, and bay, and glen;

Like Nature, true in word and deed,

Her soil was blessed with noble men. 


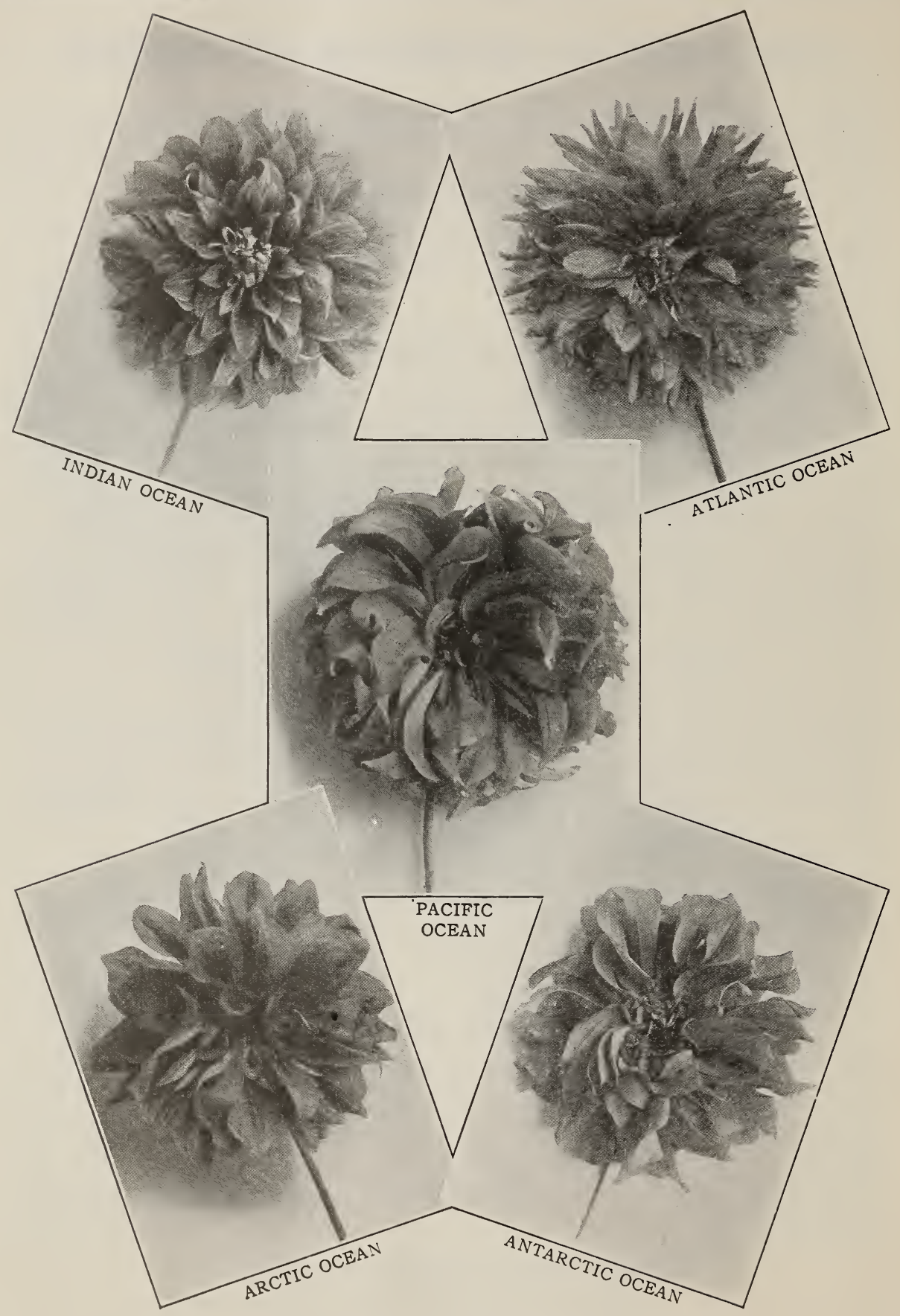

The Ocean Group 


\section{THE OCEAN GROUP}

ORIGINATED BY GEO. L. STILLMAN

NEW GROUP FOR 1923

\section{Pacific Ocean, No. 2348}

A mammoth Pæony-flowered Dahlia of a salmon pink color clouded darker in some flowers. The florets fold nicely, and twist and curl in a most exquisite manner. An exceptionally beautifully formed flower and an attractive color.

\section{Arctic Ocean, No. 2326}

Price, $\$ 15.00$

This beautiful Pæony-flowered Dahlia in color and form is all that can be desired in a dahlia. It is borne on long, stiff stems and is a beautiful peach pink with a few lines of cream. A very attractive, mammoth flower.

\section{Indian Ocean, No. 2444}

Price, $\$ 15.00$

This mammoth Decorative Dahlia is truly beautiful in color, form, and size. The color is a medium carmine red heavily clouded yellow at base of petals which are slightly clouded and veined light cream; some petals are slightly tipped yellow. A huge flower finely formed.

Price, $\$ 15.00$

\section{Atlantic Ocean, No. 2346}

This is the largest Hybrid Cactus in my collection, and of a most beautiful shade of canary yellow. A very full flower with long pointed folded petals, slightly curving. Strange as it may seem this dahlia is a very free bloomer and the flower holds to a large size very late without disbudding.

Price, $\$ 15.00$

\section{NEW SELECTIONS FOR 1921 \\ ORIGINATED BY GEO. L. STILLMAN \\ THE NEW YORK GROUP}

\section{BELMONT, No. 2069}

A beautiful, deep magenta is the color of this huge Paeony Dahlia. It is an abundant bloomer and a thrifty grower. To form an idea of the richness and beauty of this large flower one should see it growing.

Price, $\$ 3.00$

BILTMORE, No. 2008

This magnificent Decorative Dahlia is the most beautiful combination of bright, rich carmine and white ever combined in a Dahlia. The groundwork is a bright, rich carmine and the petals are more or less tipped pure white. Occasionally some flowers are nearly all carmine with a few petals tipped white. The plant hanging full of these stunning blooms presents a sight rarely seen.

Price, $\$ \mathbf{3 . 0 0}$

\section{MURRAY HILL, No. 2022}

An entirely new Paeony-flowered Dahlia of a beautiful, rich shade of purple. The flowers are simply huge in size and on good stems, which, together with their unusually attractive shade and hugeness, cause every passerby to stop and exclaim: "That's a monster." Price, $\$ 3.00$

\section{ANSONIA, No. 2064}

Without an exception the color of this large Paeony Dahlia is the most gorgeous and brightest deep canary yellow Dahlia I have ever seen. Its rich colorings never fail to catch the eye of every observer. This immense flower is carried well above the foliage on good, long, stiff stems.
Price, $\$ \mathbf{3 . 0 0}$ 


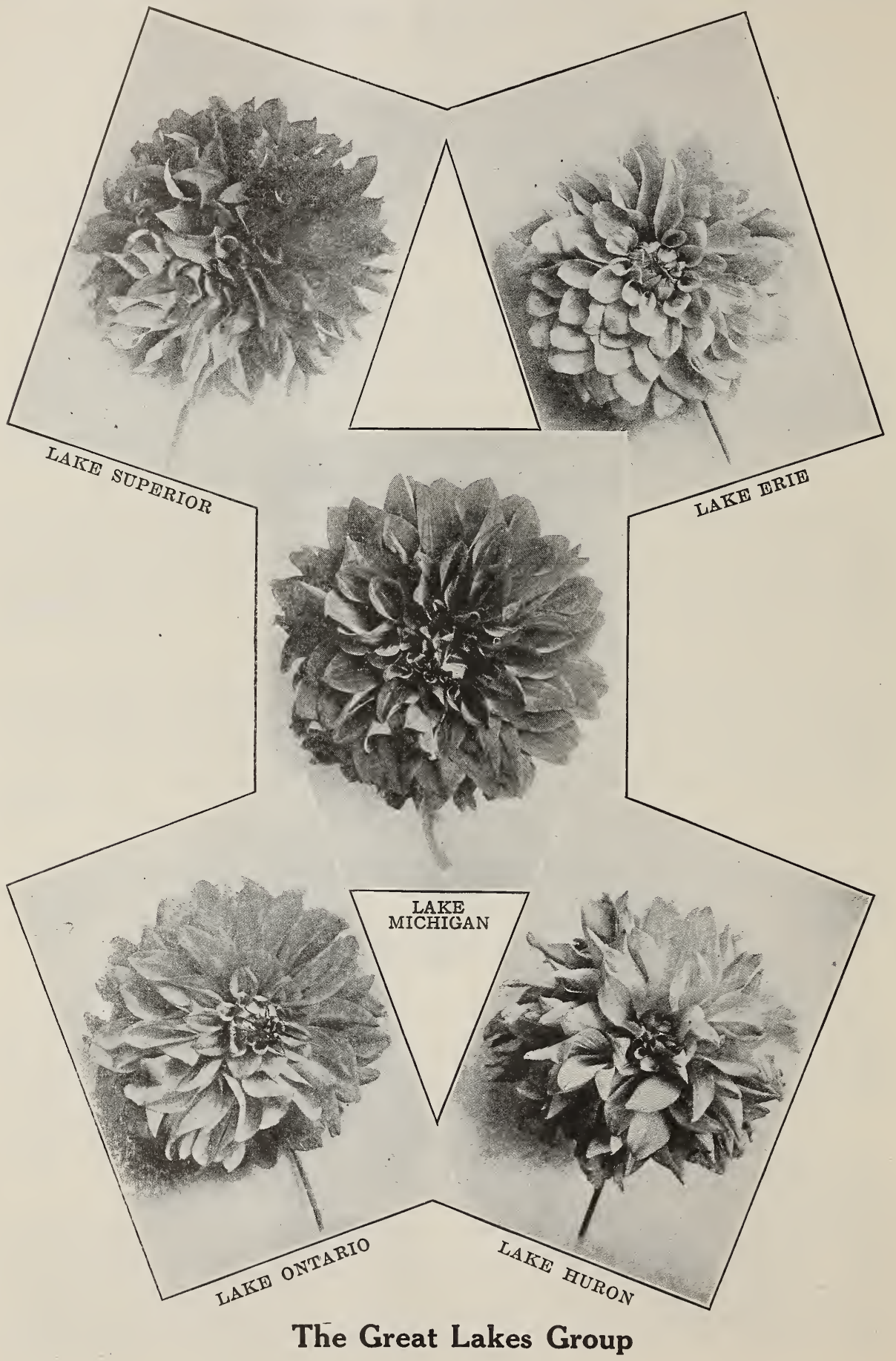




\section{THE FIVE GREAT LAKES \\ ORIGINATED BY GEO. L. STILLMAN \\ NEW GROUP FOR 1922}

\section{Lake Superior, No. 2146}

The color of this mammoth Dahlia is deep orange salmon. A solid color throughout. The formation of it is of the Hybrid Cactus class and very much resembles its parent, the "U. S. A.," but of a softer shade and promises to be a larger flower. This Dahlia will be a rich prize in any Dahlia lover's garden.

Price, $\$ 10.00$

\section{Lake Erie, No. 2216}

This is, without doubt, the largest lavender Decorative Dahlia in existence. The color is a clear deep lavender, while the form is quite flat with heavy, long, flat florets. A very unusual and beautiful Dahlia both in color and shape which can only be realized by seeing it. Blossoms from 8 to Io inches in diameter. Plants of medium height.

Price, $\$ 10.00$

\section{Lake Michigan, No. 2194}

A rich, fiery scarlet Decorative Dahlia of immense size. This is a very large, deep, heavy flower, Io to I3 inches in diameter. The stems are heavy, but the great weight of the blossom prevents it from being held erect, yet it is a wonderful exhibition Dahlia and a most attractive one in the garden. The plants are tall and strong.

Price, $\$ 10.00$

\section{Lake Huron, No. 2164}

A very large, clear, bright canary-yellow Pæony-flowered Dahlia, 7 to Io inches in diameter. This new Dahlia is a remarkable large size flower and is borne on long, heavy stiff stems which hold the flower erect. Its very free blooming qualities combined with its other unusual features place this Dahlia in the front rank. The plant is of medium height and an early bloomer.

Price, $\$ \mathbf{1 0 . 0 0}$

\section{Lake Ontario, No. 2150}

Decorative Dahlia of unusual merit. The color is salmon and gold blended together in a beautiful manner. The flower is from 6 to 9 inches in diameter and is produced on long, heavy, stiff stems. The curly, twisting formation of its florets together with its beautiful combination of colors blended together give this Dahlia a very striking appearance.

Price, $\$ 10.00$ 


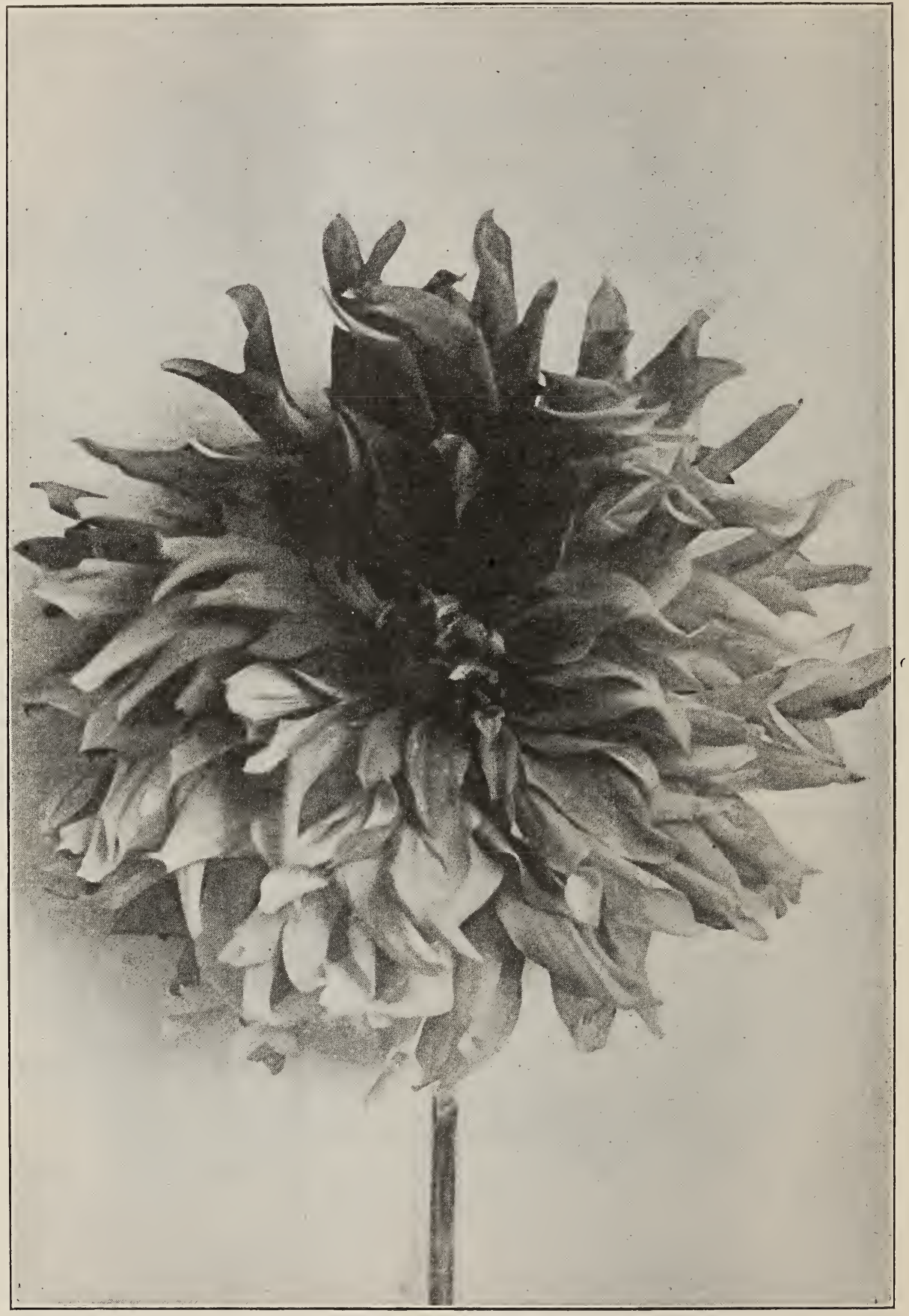

CARUSO, No. 2132 


\section{THE SEA LION GROUP \\ ORIGINATED BY GEO. L. STILLMAN}

Aquitana, No. 758. The color of this gorgeous new Cactus Dahlia is a beautiful salmon pink. The flowers are very large and are borne on long stems with scant foliage, making it most desirable for cutting.

Price, $\$ 2.00$

Empress of Asia, No. 721. A wonderfully large, fine Paeony-flowered Dahlia. The color is a deep old gold with a strikingly bronze effect. This is another of those colors so desirable and hard to get in a Dahlia. A flower of exquisite beauty.

Price, $\$ 2.00$

Lapland, No. 730. Pure, glistening white is this noble flower. The petals are broad and good formation. It is a free blooming variety and has fine stems for cutting. If you want a beautiful white, buy a Lapland.

Price, $\$ 2.00$

Mauretania, No. 738. This magnificent big, new Cactus Paeony Dahlia is simply a wonder in size, shape and color. It is a light golden mandarin, or on the light orange order. It is quite a tall growing plant and the flowers are produced in abundance. A very showy, attractive Dahlia.

Price, $\$ \mathbf{2 . 0 0}$

Medina, No. 757. This Paeony-flowered Dahlia possesses one of the most striking colors that a Dahlia could possess. A golden orange. The flower is not as large as some of the other "Sea Lions," but the color is magnificent and desirable. It has good stems for cutting and is a very valuable member of the "Sea Lion" family.

Price, $\$ 2.00$

Rochambeau, No. 811. A very bright, deep canary yellow of immense size and fine form. The Rochambeau is the tallest plant in the "Sea Lion" family, and would make a fine background in any Dahlia garden. It is a very free flowering plant and makes a fine showing above the other members of the group.

Price, \$2.00

\section{THE FIGHTING TEN ORIGINATED BY GEO. L. STILLMAN}

Gen. Bell, No. 802. Paeony. Pure, glistening white. Petals numerous; very long and quite slim, curly and twisting. A beauty beyond description, and an enormous flower on extra long stems.

Price, $\$ \mathbf{3 . 0 0}$

Gen. Cadorna, No. 643. Paeony. A bright deep yellow with a heavy shading of pink on reverse side of petals. Petals quite slim and very twisting and curly. A monster flower and is the wonder and admiration of all.

Price, $\$ \mathbf{3 . 0 0}$

Gen. Edwards, No. 2114. Paeony. Color, a beautiful salmon pink. A very large flower on fine, long stems. The formation of this flower is exquisite.

Price, $\$ 3.00$

Gen. Haig, No. 585. Decorative. A beautiful shade of peach pink, slightly clouded yellow at base of petals. A very odd and nice color and a wonderfully formed, large flower.

Price, $\$ 3.00$
Gen. Joffre, No. 638. Decorative. A light canary yellow. Petals long, broad and tapering to a point. A very deep, heavy flower of enormous size. It is a monster yet is most beautiful formed. Price, $\$ 3.00$

Gen. Mann, No. 578. Decorative. Light Du Barry. Petals rolled and twisted at point. Color much resembles Queen Esther. A fine noble flower of immense size.

Price, $\$ 3.00$.

Gen. Maurice, No. 639. Paeony. Intensely bright scarlet. The brightest mammoth scarlet Dahlia in existence. The petals are quite broad, long and pointed. The yellow disc is bright and attractive. Price, $\$ \mathbf{3 . 0 0}$

Gen. Petain, No. 647. Paeony. Butter yellow. Petals rolled back slightly lengthwise and twisting. The flower is another of the wonders in my collection of original Dahlias.

Price, $\$ 3.00$

\section{TESTIMONIALS}

Sept. 28, 1924-A lady in Conn. wrote me thus: "My only regret in raising your dahlias is that you cannot see them in all their glory. My U. S. A., Billionaire, Frieda Hempel, Ruth Thompson, Yellow Mountain, and dozens of others of yours are gorgeous beyond description and your stock is the cleanest and healthiest I have found anywhere."
Aug. 27, 1924-A gentleman in Ill. wrote me: "I thought the enclosed clipping would interest you. Every one of the dahlias are turning out fine and I have had numerous visitors who never knew that dahlias could produce such blooms and large flowers. I surely am appreciative of the selection you sent me and hope to have you send me more the ccming season." 


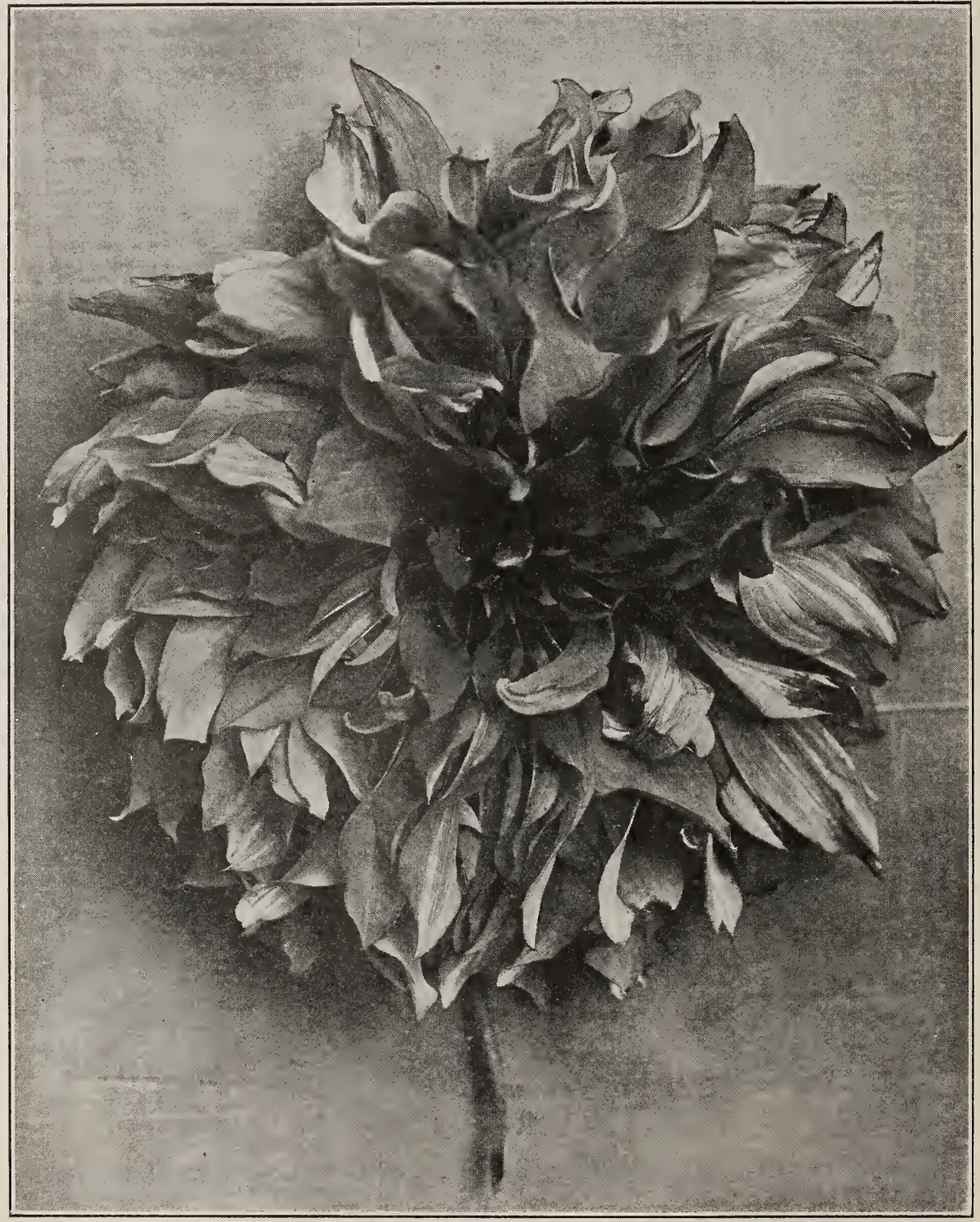

DUCHESS OF IVELLINGTON 


\section{NEW PAEONY FLOWERED DAHLIAS \\ ORIGINATED BY GEO. L. STILLMAN. THE INDIAN FAMILY}

Black Hawk, No. 54. Deep velvety maroon. The darkest flower in the Indian Family. The colorings are extremely rich and the flowers are large. The petals are broad and twisted to a point at tips. Is an extra free bloomer.

Price, $\$ 1.00$

Canonchet, No. 66. An entirely new color shading on a grayish salmon. Petals are long and rolled to a point at tips. Slightly incurving. Small petals curled up around the yellow center in very unique manner. This is a large flower and the long petals are dotted with slightly deeper small blotches of pink and suffused with a pale gold which glistens faintly.

Price, $\$ 1.00$

Canonicus, No. 1036. Beautiful dark cerise. A very unusual shade and no other Dahlia like it in shape and size has ever been produced. A large full flower. Price, $\$ \mathbf{1 . 0 0}$

Massasoit, No. 1021. Variegated. This flower is very showy and attractive. Petals being a dark maroon heavily tipped with white give the flower the appearance of being about one-third white and two-thirds maroon shade. Not as large a flower as some of the other Paeonies, but very attractive.

Price, $\$ 1.00$

Miantonomi, No. 1022. Deep amber buff with a tint of salmon pink. An entirely new and most desirable color for the Dahlia. This new and attractive color has been the admiration of all who have seen it. Many years of careful experimenting were required in producing this unusual shade. It attracts the eye of everybody.

Price, $\$ 1.00$

Minnehaha, No. 78. Light red. This is an extra large, heavy, full flower with broad petals which are slightly pointed and twisted at tips. The plant grows quite high and being a very free bloomer is one of the most showy Dahlias of the "Indian Family."

Price, $\$ 1.00$

Minnewawa, No. 76. Bright cerise red. Base of petals yellow with white disc around the centre. Balance of petals heavily clouded and tipped white. Very striking combination of colorings.

Price, $\$ 1.00$

Misquamicut, No. 1115. Golden yellow slightly tinged with pink. A very large, full flower with very broad petals, and very desirable color.

Price, $\$ 1.00$

Narragansett, No. 1033. Rich shade of dark scarlet. This flower should be seen in order to be appreciated. It is large, finely formed, and a very full flower. It blooms very freely and has been a general favorite wherever exhibited.

Price, $\$ 1.00$

Ninigret, No. 151. Rich dark red, clouded and striped much lighter. The petals taper abruptly to a sharp point which is twisted in a very attractive manner. A full, heavy flower of unusual quality. $\quad$ Price, $\$ 1.00$

Nokomis, No. 1112. Variegated yellow. The base of the flower is white and canary yellow mixed together. Heavily striped and speckled with dark red. Occasionally solid red blooms appear on the same plant. The plants are of a low growth and flowers stand high above the foliage.

Price, $\$ 1.00$

Pocahontas, No. 69. Light cream yellow. This flower is very large with flat, broad petals except in the centre. Petals are flushed and veined deep pink, possessing some of the colorings of the Geisha. A very free bloomer and in every way desirable.

Price, $\$ 1.00$

Powhatan, No. 101 Dark crushed straw. berry. This very large flower is another of unusually fine shading. While it has the colorings of the crushed strawberry, it also possesses a light tint of lavender and the free-blooming qualities. Price, $\$ 1.00$

Queen Esther, No. 103. Color, "Du Barry," that dazzling new shade of red. An enormous, large full flower and a beautiful rich color. The small twisting florets in the center of this flower give it a most unique appearance. A wonderfully free blooming Dahlia.

Price, $\$ 1.00$

Red Cloud, No. 84. Rich deep carmine. This is a large, full flower of a solid color and is borne in abundance on a plant of high growth.

Samoset, No. 1007-1. Light yellow. Some of the petals of this flower are slightly shaded with pink, while the whole flower is full and of the true Paeony type. Small curly petals on the face of this flower give it a very desirable effect. A very free blooming variety.

Price, $\$ 1.00$

Squanto, No. 102. The color of this Dahlia is hard to describe on paper. It is of a reddish violet, growing more red at the base of petals. The flower is large and makes a very showy plant by its free-blooming qualities.

Price, $\$ 1.00$

Uncas, No. 147. Pure white. A beautiful pure white somewhat resembling South Pole, but petals more curly and twisted. A very unique shaped, free-blooming Dahlia, and exceptionally desirable. Price, $\mathbf{\$ 1 . 0 0}$

Wadawannock, No. 1034. Light coral. This is a large flower with broad, flat petals and with just enough twisting, curling petals in the center to give it a nice Paeony effect. This is an entirely new shade and one of those very effective and desirable colors seldom seen in the Dahlia. Price, $\mathbf{\$ 1 . 0 0}$ 


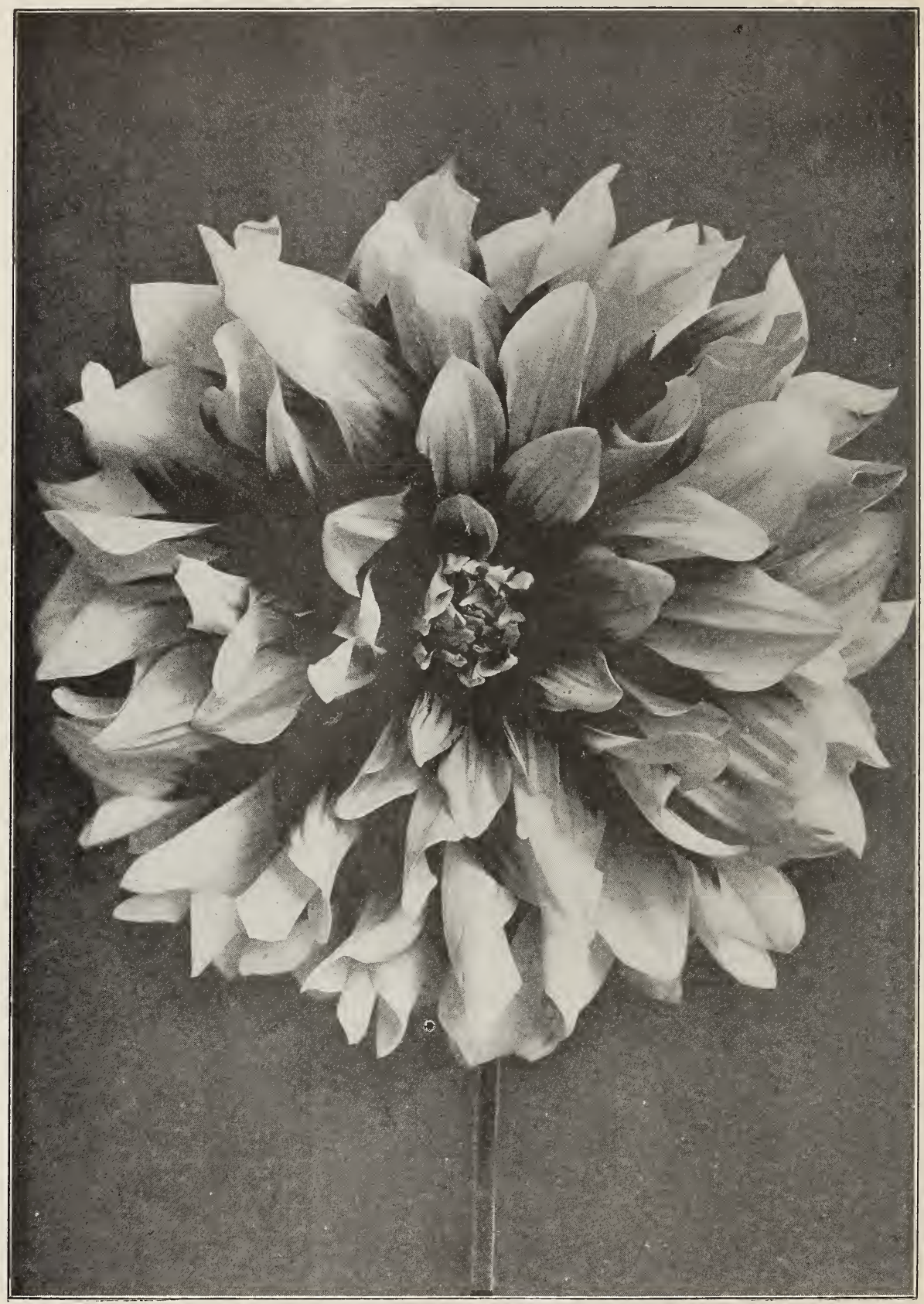

ALLEGHANY MOUNTAIN 


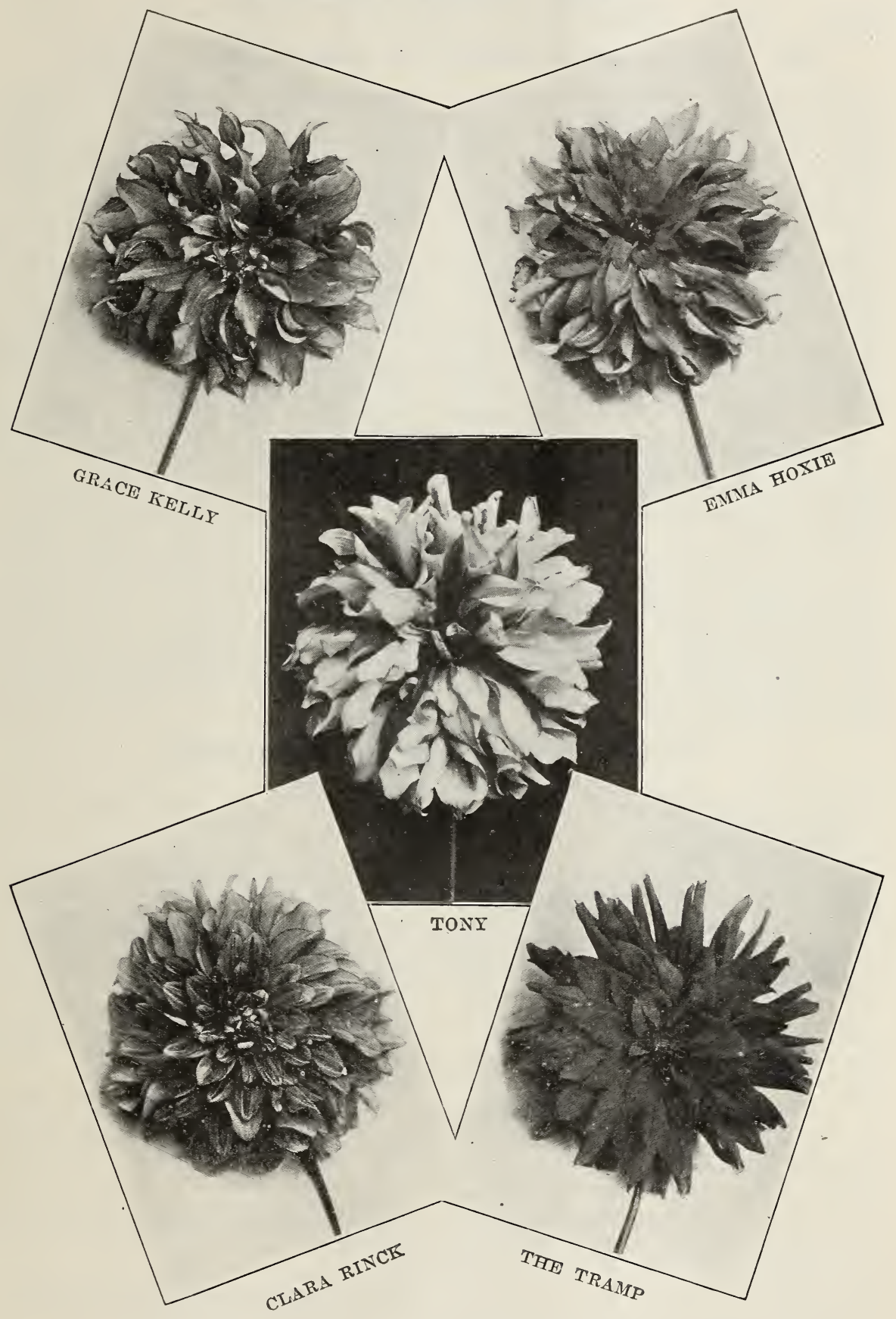




\section{THE LOMA FAMILY \\ ORIGINATED BY GEO. L. STILLMAN}

\section{THE EIGHT BROTHERS OF THE LOMA FAMILY}

Alan Loma, No. 459. A pure waxy white Pæony-flowered Dahlia with large broad flat petals. Very prominent yellow pollen disc with a few small curling petals around it. A large, heavy flower. Certainly a splendid specimen. Very erect on long stout stems.

Price, $\$ \mathbf{1 . 0 0}$

Eugene Lomáa, No. 418. A light canary yellow to the center of this fluffy Pæonyflowered Dahlia. The shading runs lighter toward points and the very faintest of pink shows on sides and back of petals. Petals slim and rolled to a cup, twisted and curled around the center in a very peculiar manner. A very unusual flower. Erect on good stems.

Price, $\$ 1.00$

Forest Loma, No. 468. Deep cerise pink Pæony-flowered Dahlia, blotched and streaked canary yellow, with yellow at center. Petals are finely formed and numerous and curled at points. Very large and another erect specimen on good stems. Price, $\$ \mathbf{1 . 0 0}$

Harry Loma, No. 438. A pretty pink Pæony-flowered, streaked artistically with white and with a faint bluish cast at tips, giving a lavender hue. A full flower with very curly petals in center. Another specimen with extra long stems. Petals long, slim, numerous, and sharply pointed.

Price, $\$ 1.00$

Kenneth Loma, No. 422. A lovely, clear, light canary yellow, or lemon, shading makes this a fine specimen in its family. It is of the Decorative style, standing very erect on good, strong stems, and a very large flower. Nice fluffy petals slightly curled. A gorgeous flower and unusually fine clean color.

Price, $\$ 1.00$

Robert Loma, No. 490. Golden amber shaded slightly with salmon pink, pink showing more on backs of petals, of full Pæony type. Good size with long stems. This is one of the new attractive colors so desirable in the flower garden.

Price, $\$ 1.00$

Rupert Loma, No. 456. A dull, old rose shading runs predominantly through the petals of this Dahlia, while a noticeable amount of lavender touches many of the petals' tips. It bears the appearance of being streaked lighter and darker shades of the rose and lavender. Difficult to describe. It has a very full blossom of perfect form, of Decorative type. Good size, standing boldly on its long, stout stems. This Dahlia's foliage is beautiful and scant in appearance, with long, jointed stalks. Price, \$1.00

Stephen Loma, No. 1370. A very pleasing dark magenta of Pæony flowered type. Very full toward center with slim, nicely formed petals. Extra large size, with stout stems.

Price, $\$ 1.00$

\section{TOWN COURT OF STONINGTON}

Mr. George L. Stillman, STONINGTON, CONNECTICUT

Dahlia Specialist,

Westerly, Rhode Island.

Dear Mr. Stillman :-

I wish to acknowledge the high honor conferred upon me by naming one of your latest and choicest Dahlia Varieties the "Judge Wilcox," the size, beauty and form of rich golden color of this Dahlia is a charm in itself.

I have noted your progress as a Dahlia grower for years and from the fact that you are the originator of one thousand varieties and are placing dahlia bulbs on the market at a hundred dollars a bulb proves conclusively that you are indeed a Dahlia Specialist, and may the "Judge Wilcox" be one of your best sellers. This is the wish of, Yours most sincerely,

WILLIAM A. WILCOX.

\section{Note the Following}

Do not plant your Dahlias in the shade.

Stunted plants, thick and bushy on top, with no blossoms, are the result of dry weather, or too heavy soil.

I guarantee every bulb I send out.

Do not wait for bulbs to sprout before planting. There is nothing like mother earth to sprout them. Plant them where you want them to grow.

The more flowers you cut the better Dahlias bloom.

Dahlias do well with me; they will with you, if you will follow my instructions carefully, and above all, note what is said on another page in regard to watering. 


\section{NEW ORIGINAL INTRODUCTIONS FOR 1925}

\section{ORIGINATED BY GEO. L. STILLMAN}

Barton Edwards, No. 2622. Color, a reddish brown. Center petals slightly shaded yellow. Petals rather slim and slightly twisting. A very odd color and a beautiful large dahlia.

Price, $\$ 5.00$

Beauty Face, No. 2648. Decorative. Color, deep canary yellow. The petals are tri-colored. Yellow tipped with pink and yellow tipped white. A very pretty attractive flower of medium size. A beautiful combination of colors.

Price, $\$ \mathbf{2 . 5 0}$

Canary Reliance, No. 861. Decorative. light canary yellow. A large flower with medium dorsaw petals and of good form.

Price, $\$ 3.00$

Charlene, No. 2604. Color, light salmon on face of petals while back side are much darker. Petals are wide and twist to a point. Flowers are held on good stems. A very profuse bloomer.

Price, $\$ \mathbf{7 7 . 5 0}$

Duchess of Wellington, No. 2611. Hy. Cactus. Color, pure, clear canary yellow. This flower is one of the largest in cultivation. In my field in 1924 without any disbudding, watering, or any application of fertilizer since planting, it measured over 10 inches across; and at the same time there are other blossoms nearly open and quantities of buds. Its natural growth was thus demonstrated. As one person said who saw it "it's a whopper."

Price, $\$ 75.00$

Epinard. No. 2528. Paeony. Canary yellow. Petals, which are many, are quite folding and shaded pink in center, these possess a tendency to curl and twist which adds much beauty to the dahlia. Price, $\$ \mathbf{5 . 0 0}$

Firey Indian, No. 2649. Hy. Cactus. Color, bright scarlet red. A finely formed flower on good stems.

Price, $\$ \mathbf{5 . 0 0}$

Garden Beauty, No. 2573. Hy. Cactus. Color, pure white with very faint lavender tips. Petals curl and twist in a beautiful manner. A deep full flower. Price, \$5.00

Happy Land, No. 2672. Paeony. Color a very deep peach pink. Petals slightly fold forward with a tint of yellow at base.

Price, $\$ 3.00$

Jim Henry, No. 2621. Decorative. Color reddish salmon heavily clouded yellow at tips of petals and at the base of petals. A red salmon predominates.

Price, $\$ \mathbf{2 . 5 0}$

Judge Wilcox, No. 2656. Decorative. Color, clear butter yellow. The flowers are large and stand up on stiff stems. One of the best for cutting.

Price, $\$ \mathbf{5 . 0 0}$

Koman, No. 2532. Ground color yellow while the flower is heavily clouded with a rich red salmon. A beautiful combination of colors. Tips of petals twist beautifully.

Price, $\$ 5.00$
Lady Christy, No. 2507. Decorative. Color, yellow heavily lined and clouded pink. Center of flower quite yellow. Petals curl and twist at points. A beautiful flower.

Price, $\$ \mathbf{5 . 0 0}$

Ladies' Delight, No. 2691. Paeony. Color, deep lavender and pink clouded together. Petals fold forward and some have large blotches of white in the center. $A$ very odd combination and beautiful.

Price, $\$ 5.00$

Lilac Gem, No. 2652. Decorative. Color, light lilac with the inner petals a shade lighter. A very nice dahlia, of good desirable color, held on good stems. $\quad$ Price, $\$ 3.00$

Mrs. M. E. Foster, No. 2666. Hy. Cactus. Color, nice canary yellow striped and veined red. A large size flower held erect on long branching stems. One of the best hybrid cactus. A most profuse bloomer with a full center. This dahlia is a prize in any garden. $\quad$ Price, $\$ \mathbf{5 0 . 0 0}$

Mrs. Marshall, No. 2676. Hy. Cactus. Color, clear butter yellow. Petals wide and rolled to a sharp point. A deep full flower overcast with pink. A beauty. Price, $\$ \mathbf{1 5 . 0 0}$

Orange Bride, No. 2685. Paeony. Color, a deep orange salmon, heavily clouded o. shaded pink. A heavy flower with pointed petals. In this flower the orange predominates, making a very desirable color.

Price, $\$ \mathbf{2 . 5 0}$

Razeldazzle, No. 2628. Paeony. Color, light carmine red with each petal heavily tipped white. This is a very showy flower and is held erect on good stiff stems. Very desirable.

Price, $\$ 3.00$

Red Man, No. 2608. Color, rich deep velvety carmine red. Petals fold forward and curl to a sharp point. A fine red on good stems.

Price, $\$ \mathbf{5 . 0 0}$

Ritchie, Dec. No. 2675. Color, rich carmine red; petals heavily tipped white. A beautiful large flower on heavy stems. Some of the blooms come solid red on some plants.

Price, $\$ 5.00$

Rocky Mt., No. 2537. Paeony: Color, a red salmon. Base of petals show a fine line of yellow and are very curly around the center. A mammoth flower with exquisite shadings and beautiful color. Price, $\$ \mathbf{1 5 . 0 0}$

Scarlet Pure, No. 2668. Hy. Cactus. Color, bright scarlet. Petals very curly and twisting. A large flower with a nice full center.

Price, $\$ 5.00$

Senator Spencer, No. 2340. Decorative. Canary yellow shaded heavily with salmon. A large heavy flower and fine color. Price, $\$ 5.00$ 


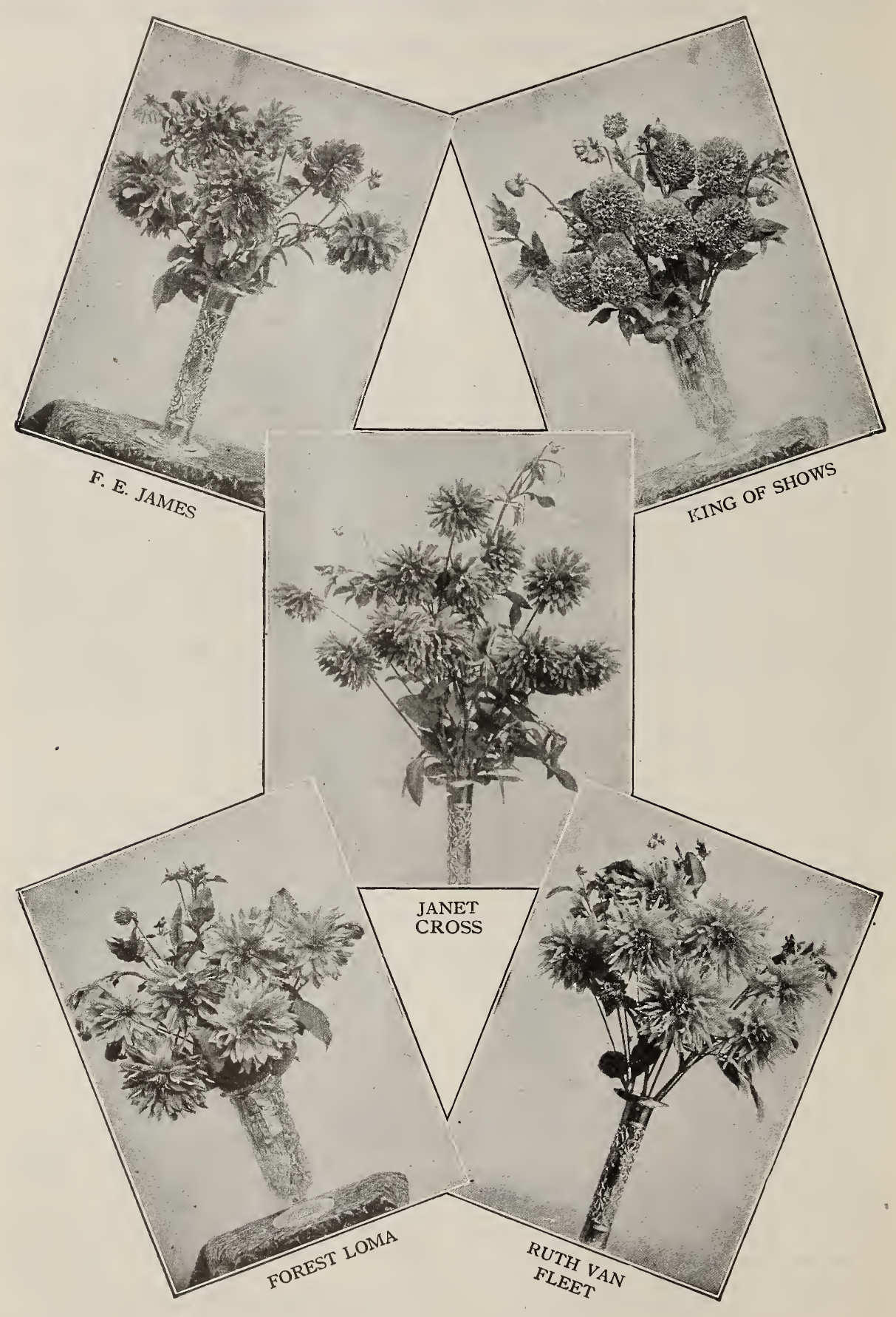




\section{ORIGINAL INTRODUCTIONS FOR 1925-Continued}

Shower of Gold, No. 2698 Hy. Cactus. Color, a fine shade of gold with inner petals shaded lighter. Petals are sharp, pointed, and slightly curled. A rich nice flower of medium size.

Price, $\$ 5.00$

Sierra Nevada Mt., No. 2521. Decorative. Salmon pink with petals slightly clouded with yellow at base, while the inner petals are heavily clouded yellow and curl at the tips. A nicely formed flower on good stems.

Price, $\$ 10.00$

Silver Moon, No. 2660. Hy. Cactus. Color, dark butter yellow with inner petals shaded lighter. This is a nice flower and is a prize in any garden.

Price, $\$ 3.00$

The Elks, No. 2540. Paeony. Color, deep purple magenta. Petals fold forward and curl in the center. A large size and finely formed dahlia.

Price, $\$ 10.00$

The Gay Dancer, No. 2647. Paeony. Color, a bright carmine with petals heavily tipped white and twisting to a point at tips.
Some petals are entirely red in some blossoms. The blooms are held erect on long stems. A very showy dahlia and of good size for cut flowers.

Price, $\$ 5.00$

The Lilac Prince, No. 2659. Paeony. Color, pure lilac, shaded lighter at the base of petals. A beautiful, large dahlia of very desirable form and color.

Price, $\$ \mathbf{5 . 0 0}$

The Old Home, No. 2644. Paeony. Color crushed strawberry; petals slightly veined darker. A very odd color and a fine large flower.

Price, $\$ 10.00$

The Richest Prize, No. 2639. Paeony. Color, lavender pink heavily veined and clouded yellow. A fine flower of a rather unusual color and mammoth size.

Price, $\$ 15.00$

Weekapaug, No. 2606. A purplish deep red, rather an odd color. This is a large flower. The petals are nearly flat and are shaded through with darker. Price, $\$ \mathbf{5 . 0 0}$

\section{THE LOMA FAMILY}

\section{ORIGINATED BY GEO. L. STILLMAN}

\section{THE EIGHT SISTERS OF THE LOMA FAMILY}

Edna Rollins, No. 1460. Pæony-flowered Dahlia blotched with old rose. Streaks of yellow near center and slightly through petals. Light blotches of dull yellow mingle faintly with the dull rose. Numerous small curly petals around center of flower. Good size on long stems.

Price, $\$ 1.00$

Esther Du Barry, No. 489. A beautiful clear, velvety cardina1 with long, slimly rolled petals, nice Pæony type, which twist and curl beautifully at points. Numerous small petals around central disc. Extra long, stiff stems which hold the flowers very erect.

Price, $\$ 1.00$

Evelyn Loma, No. 448. A fluffy white Pæony-flowered Dahlia with long, slim pointed petals, curled and rolled in a pleasing manner. The very base of petals is slightly shaded yellow. A fine, large specimen erect on extra long stems.

Price, $\$ \mathbf{1 . 0 0}$

Frances Lane, No. 322. Pretty light, velvety lavender red Pæony-flowered Dahlia with pale lavender which streaks down through the main petals. Petals broad and flat with tips slightly curled. A pleasing, striking specimen. Erect on good stems. A noticeable circle of canary yellow surrounds the pollen disc.
Hazel Van Allen, No. 1498. A lovely reddish magenta of the Decorative type, slightly shading cerise and clouded at base of petals lighter. A full, large flower with narrow, nicely formed petals. Erect on long, strong stems.

Price, $\$ 1.00$

Janet Cross, No. 432. A finely pointed Cactus type of a lovely shade of very rich salmon pink, almost clear save for a very few faint yellow petals in the center, which are finely bordered with pink. A large size Cactus on good stems. A fine specimen. Unusual long, stiff stems often measuring 16 inches.

Price, $\$ \mathbf{1 . 0 0}$

Ruth Van Fleet, No. 1451. Clear light canary yellow. The stems are extra long, often measuring 16 inches. The flowers are extremely large, measuring from 6 to $8 \frac{1}{2}$ inches in diameter and are held perfectly erect on its stiff, long stems. Hybrid Cactus. It should be seen to be appreciated.

Price, $\$ \mathbf{2 . 0 0}$

Vivian Jacoy, No. 1450. A mingling of white and light cerise, streaked and blotched through entire petals of a Pæony type. Petals toward center curl very pleasingly. An odd and pretty specimen on long stems, and a good sized flower.

Price, $\$ 1.00$ 


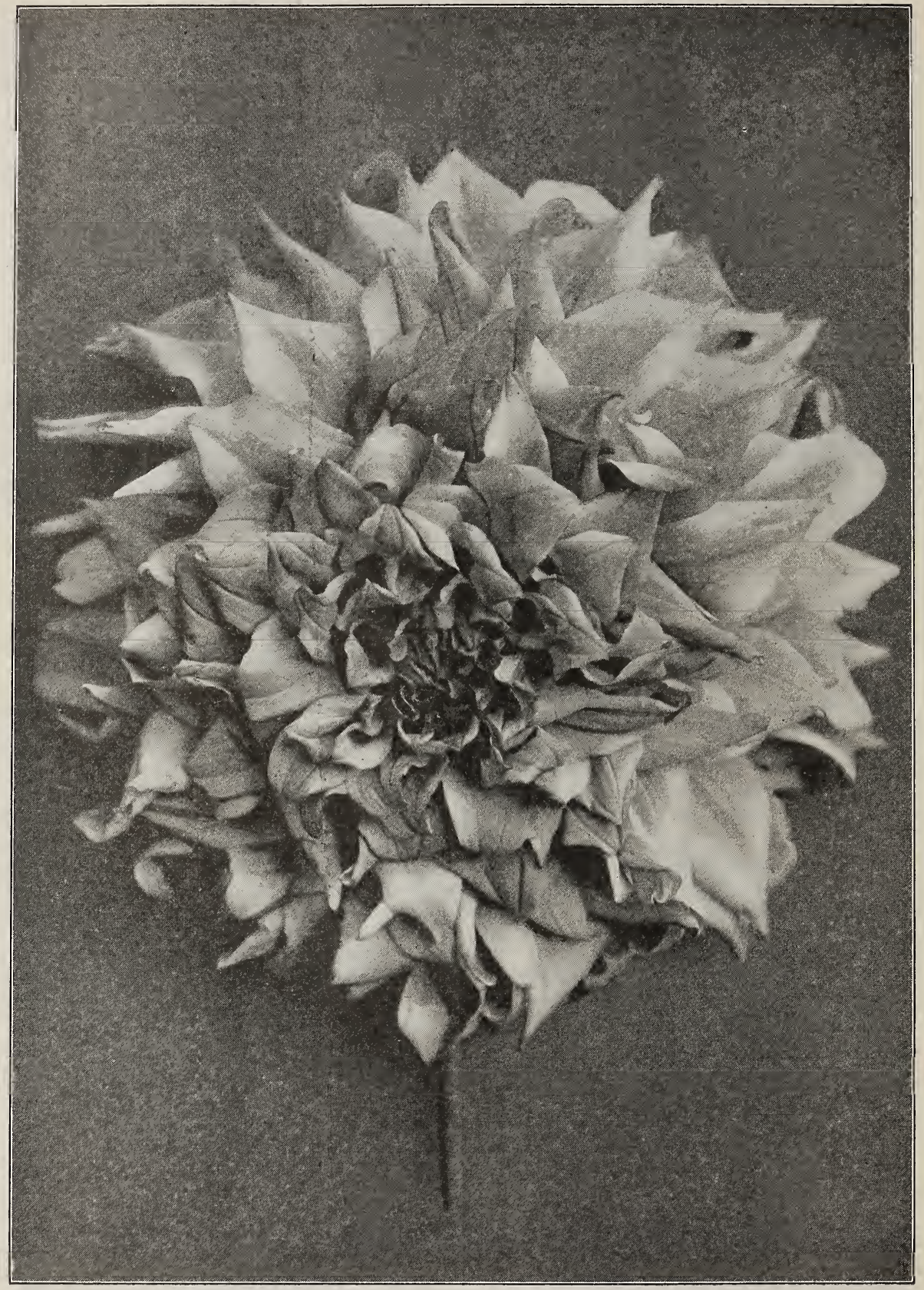

DR. WALTER VAN FLEET 


\section{NEW DECORATIVE DAHLIAS \\ ORIGINATED BY GEO. L. STILLMAN}

"Our Country," No. 2458. The color combination of this wonderful, new decorative Dahlia is superior to anything I have ever produced in a dahlia. The ground or main color is a very deep purple while the florets are heavily tipped pure white. It is truly a mammoth and the formation is truly wonderful. It is a very deep, heavy flower with a never failing center. The colors run very uniform. It has never been known to produce solid purple, or white flowers as in many cases with variegated dahlias. It was offered to the public in 1923 for the first time. Price of bulbs or plants

$\$ 25.00$ each.

Baby Mae, No. 700. This unique flower is a beautiful shade of lavender pink changing to a lighter shade in center. It is nearly a duplicate in color to the Millionaire, but much smaller in size.

Price, $\$ \mathbf{1 . 5 0}$

Beacon Light, No. 591. White changing to a beautiful cream at base of petals. A most clear, beautiful flower. Fine for cutting. The formation of this flower together with the color is most desirable. Price, $\$ 2.00$

Black Beauty, No. 534. Nearly black. Medium sized flower larger than Eng. Blk. Prince.

Price, 75c.

Bolton, No. 1424. Golden amber. Flowers good size and odd color. Good length of stem.

Price, 50c.

Bonny Best, No. 577. Very light cream and shaded darker at base. Petals, broad and serrated at tips. A most beautiful, clean color and a good sized flower on heavy stems.

Price, $\$ \mathbf{1 . 0 0}$

B. P. O. E. No. 2324. Color, light purple or lilac. A large deep full flower held on good stout stems. This is a Dahlia of more than usual merit. The color is a very desirable one and it combines many desirable features that few Dahlias possess.

Price, $\$ \mathbf{5 . 0 0}$

Capt. Eri, No. 2535. Color, a nice deep orange with center petals shaded butter yellow. The petals are broad and curling, and twist at the points. A most beautiful flower.

Price, $\$ 5.00$

Clara Annette, No. 731. The color of this Dahlia is a rich, medium shade of carmine red. Each petal is slightly veined yellow and slightly tipped yellow. It is a fine flower in every respect and should be in every Dahlia garden.

Price, $\$ \mathbf{1 . 0 0}$

Clara Barton, No. 2145. The color is a very deep orange brown. The color of this Dahlia is very hard to describe with any accuracy, but it is a most desirable color. It is a Dahlia of wonderful formation, and it is truly a mammoth. It somewhat resembles its parent the U.S. A., but the color is slightly darker. This beautiful Dahlia is an unusually free bloomer, which fact, together with its mammoth size, make it worth a place in every Dahlia fancier's garden, both as an exhibition Dahlia and for garden decorations.

Price, $\$ \mathbf{5 . 0 0}$

Daniel Webster, No. 566. Deep blush rose pink. A very odd and striking color.
Petals are quite slim and tapering to fine points, also have a rolled and twisted appearance. The outer edge of each petal is bordered with a much lighter shade.

Price, 50c.

Douglas Fairbanks, No. 442. Crushed strawberry shaded to yellow at base.

Early Fortune, No. 2300. Color, light canary yellow, darker in center and shaded to white at tips. A very clean nice color. A flower blooming very early. Price, \$2.00

Eee Zee, No. 2403. Color, a deep rich salmon pink. A very rich desirable color. Flowers on fine stems for cutting. A free bloomer.

Price, $\$ \mathbf{5 . 0 0}$

E. J. Pease, No. 1428. Fire red. Slight veins of yellow running lengthwise through petals giving the flower a prominent striped appearance.

Price, $\$ \mathbf{1 . 0 0}$

Emma Hoxie, No. 795. Color, light gold with cloudings of pink. The florets are quite slim and curling, forming a most beautiful flower in shape, color, and large size.

Price, $\$ 3.00$

Florence Griswold, No. 2267. Color, white. Each petal clouded and stained red at base. A medium sized flower, but very showy.

Price, $\$ 2.50$

Florence Nightingale, No. 2325. Color, butter yellow with slight veins of salmon. Petals fold to a sharp tip. Price, $\$ \mathbf{5 . 0 0}$

Florine, No. 975. This new Decorative Dahlia is certainly desirable. The color is a beautiful shade of golden apricot. The flower is of a beautiful Decorative formation. A very free bloomer. The blossoms are borne on good stems. Price, $\mathbf{\$ 2 . 5 0}$

Gen. Markel, No. 750. A rich deep carmine in color and very bright. A deep, full flower which is much admired for its rich coloring.

Price, $\$ 1.00$

N. C. 4, No. \$01. This wonderful new Decorative Dahlia is a most unusually hard Dahlia to describe, as it is about equally divided with scarlet and white. The florets are more or less striped the whole length with yellow and white, while some are slightly clouded with yellow and tipped with light cream. The reverse side of petals is white with yellow shadings. The whole flower is simply beautiful and unusually attractive.

Price, $\$ 3.00$ 



\section{NEW DECORATIYE DAHLIAS-Continued}

Gladys L., No. 1018. Rich soft shade of light magenta. A very heavy, deep flower on long stems. Each petal is deeply serrated at tips. One of the finest Decoratives. Price, 50c.

Hall Mark, No. 2225. Color, light canary yellow. A deep, full flower and a very clear, nice shade. This Dahlia can be grown to an immense size with a little care. Price, $\$ \mathbf{5 . 0 0}$

Hocus Pocus, No. 2401. Color, a yellow salmon, or very light red, while some florets are nearly white and occasionally flowers are more than half white. A large flower and a very odd, but attractive combination.

Price, $\$ 3.00$

Immensity, No. 2262. Color, a pure orange. A very attractive flower on good stems. A very desirable and unusual color.

Price, $\$ \mathbf{2 . 5 0}$

International, No. 2218. The color of this flower is strikingly odd and a true novelty. It is a sort of fawn color with cloudings of yellow and darker fawn. A nicely formed Decorative with a full center. Price, $\$ \mathbf{5 . 0 0}$

John Drew, No. 581. A very light pink, while the reverse side of the petals is darker pink. This is an elegant, large, full flower and should be seen to be appreciated.

Price, $\$ 3.00$

Justice White, No. 2196. Color, bright carmine with each petal nearly half white at tips. A very large fluffy flower on good strong stems. Occasionally a flower comes solid carmine or nearly so. When grown to perfection this Dahlia is of immense size and a beauty.

Price, $\$ \mathbf{5 . 0 0}$

King Arthur, No. 307. A rich garnet red, solid color. This flower when beginning to bloom somewhat resembles a Narcissus, as the outer petals open usually about a day before the others begin to unfold. It is of large size and a beautiful Decorative shape with extra good stems. For richness of coloring this Dahlia is seldom equalled.

Price, $\$ 1.00$

King of the Garden, No. 2435. Color, light pink and yellow combined. Some flowers are nearly all canary yellow; others are yellow at base of petals and nearly white at the tips; and still others are almost white with yellow shadings. These differently marked blossoms are all found on the same plant. A very beautiful Dahlia possessing very unusual soft shadings and a fine long stem.

Price, $\$ 15.00$

Lady Betty, No. 1330. Nice rich, velvety purple with reddish cast. Good size, nicely formed petals, quite numerous. Very attractive.

Price, $\$ \mathbf{1 . 5 0}$

Lady Cardine, No. 2017. A large flower of the Decorative type and slightly oval face. The color is a medium rich car- mine and each petal heavily tipped white. Occasionally a petal is bordered with gold on one side. One of the most beautiful flowers grown and on heavy stiff stems. A wonderful free bloomer.

Price, $\$ 3.00$

Lady Fenwick, No. 2548. Color, a beautiful shade of peach salmon or peach pink. A very desirable shade. Good size flower on good stems for cutting. $\quad$ Price, $\$ \mathbf{1 0 . 0 0}$

Lady Lenox, No. 2374. Color, medium orange and medium in size, but very good both in color and form. Some flowers come clouded white, but an extra nice Dahlia.

Price, $\$ \mathbf{5 . 0 0}$

Mabel Normand, No. 1005. Very light canary yellow. A nice clean colored flower on good stems.

Price, $\$ 1.00$

Marcelline, No. 1353. Pure glistening white. Petals wide and curled, twisted in various shapes. Very long stems. Good sized flowers.

Price, $\$ 1.00$

Mary Sefton Thomas, No. 509. Canary yellow. Petals broad and pointed. Very heavy flower of a beautiful shade and shape. Large size and good stems. Very attractive.

Price, $\$ 2.00$

Marillyn Miller, No. 2144. Color, salmon, heavily shaded yellow. This is a medium sized flower, but has extra nice stems for cutting, making it a very desirable cut flower Dahlia of a fine color.

Price, $\$ 1.50$

Mme. Etta, No. 1430. Very dark lavender pink. Petals long, slim, rolled and twisted. A very full, large flower. Good length of stem. A nice. specimen and very desirable.

Price, $\$ \mathbf{2 . 0 0}$

Meadow Vale, No. 2112. The color of this beautiful Dahlia is light canary yellow. Each petal is heavily tipped white. The softness of the colors of this medium sized Dahlia makes it a most wonderful and desirable flower. It is borne on good stems for cutting. A basket of these Dahlias presents a most striking appearance. A Meadow Vale should be in every Dahlia lover's collection.

Price, $\$ \mathbf{2 . 0 0}$

Mongolian, No. 1092. Very dark maroon. Nearly black. Medium sized flower and a very free flowering Dahlia.

Price, 25c.

Mr. Layng. Color is a deep pink with lighter shadings. This is a mammoth flower on fine stems for cutting. A very free blooming and attractive Dahia.

Price, $\$ \mathbf{2 . 0 0}$

Mrs. A. H. Smith, No. 888 . Color, a beautiful light canary yellow. A very large flower on good stems and is a prize in any garden. 


\section{NEW DECORATIVE DAHLIAS-Continued}

N. C. 4, No. 901. This wonderful new Decorative Dahlia is a most unusually hard Dahlia to describe, as it is about equally divided with scarlet and white. The florets are more or less striped the whole length with yellow and white, while some are slightly clouded with yellow and tipped with light cream. The reverse side of petals is white with yellow shadings.

Price, $\$ 3.00$

Orange Prince, No. 2392. Color, light butter yellow. A clean, nice color and a nicely formed flower. Petals curl at tips. A very desirable large flower. Price, $\$ 3.00$

Our Country, No. 2458. The color combination of this wonderful, new decorative Dahlia is superior to anything I have ever produced in a Dahlia. The ground, or main color is a very deep purple while the florets are heavily tipped pure white. It is truly a mammoth and the formation is truly wonderful. It is a very deep, heavy flower with a never failing center; and the colors run very uniform. It has never been known to produce solid purple, or solid white flowers as in many cases with variegated Dahlias. It was offered to the public in 1923 for the first time.

Price, $\$ 25.00$

Oweenee, No. 1117. Variegated cerise and white. This flower is of very delicate coloring, petals being fine and very numerous. They are splashed and clouded with light cerise and white. One of those very desirable light shades.

Palisade, No. 2524. Color, light butter yellow slightly overcast with pink. Petals rather narrow and slightly folding forward. A fine decorative Dahlia on the best of stiff stems holding the blossoms erect.

Price, $\$ 5.00$

Plato, No. 799. Color, salmon red. A nice colored flower and about same shape as Mrs. Roosevelt. On fine, long, stiff stems for cutting. A very profuse bloomer.

Price, $\$ 1.00$

Perfect Beauty, No. 582. Bright light scarlet. Outer ends of petals heavily tipped white. The colors are divided about equally, half red and half white. A most beautiful flower of very large size. One of the most attractive flowers imaginable. Price, $\$ \mathbf{3 . 0 0}$

Pride of the Garden, No. 2032. Color, deep canary yellow with petals tipped white. Occasionally some flowers come all yellow and in that case is a most beautiful flower. The flowers are large and the buds which appear in numbers should be pinched off to one in a place. It is truly a pride in any garden.

Price, $\$ 5.00$

Pride of the West, No. 518. Golden orange. A very full, desirable colored flower. Good size on long stems. Very attractive.

Price, 75c.

Purse of Gold, No 2305. Color, deep butter yellow. A Dahlia as good as a purse of gold. A very large flower and a full decorative pattern with long stems. The color would be hard to beat. Price, $\$ 10.00$

Robert O. Fletcher, No. 2271. Colcr, white striped and speckled with bright carmine. A beautiful flower and a lovely combination of colors.

Price, \$3.00

Sierra Nevada Mt., No. 2521. Color, salmon pink, slightly. clouded yellow at base of petals, while the inner petals are heavily clouded yellow and curl at the tips. A nicely formed flower on good stems. Price, $\$ \mathbf{1 0 . 0 0}$

Snowdrift. Color, pure white. This is a remarkably large fine white flower. The plant grows low and the flowers are well above the foliage.

Summer Favorite, No. 2443. Color, butter yellow heavily overcast with salmon. Flowers are very curly at the tips of petals and are held erect on stiff stems. A fine cut flower Dahlia.

Price, \$2.50

The Millionaire, No. 1420. This rcmarkable mammoth new Decorative Dahlia exceeds any other Dahlia in existence in size. The color is a most dainty lavender with a pink sheen overcast. The flower is simply immense, very deep and heavy. After the first flower, it is produced on extra long, heavy stiff stems. The Millionaire has won many first prizes, besides many medals, all over this country for the largest flower in the show. A Dahlia garden is not complete without a Millionaire. Price, $\$ 1.00$

The Deacon, No. 2391. Color, very light red. A very deep, heavy large flower on long stems and a very profuse bloomer. By disbudding this Dahlia would reach an 1mmense size. $\quad$ Price, $\$ \mathbf{5 . 0 0}$

Timothy, No. 2427. Color, deep orange is the main color, but in some flowers all the petals are tipped white. A beautiful flower in either color and of medium size for cutting.

Price, $\$ 1.50$

The World Court, No. 2687. Color, canary yellow heavily clouded and striped with pink and fawn. Yellow shows more prominently in center of the flower. It possesses heavy, wide petals with a never failing center. A huge flower on long stems. One of the Dahlias without any disbudding or special care with four other blooms and a half dozen buds on the plant measured over 9 inches across. With disbudding the size is unlimited. Price per bulb, $\$ \mathbf{1 0 0 . 0 0}$

Watch Nill, No. 588. The color of this new Decorative Dahlia is a light pink of a beautiful shade. A nice deep flower of large size and one of those very desirable colors for the home garden.

Price, $\$ 1.00$ World's Wonder, No. 550. Color, golden salmon. Low plant and an early bloomer. This is a very large, deep, full flower with almost a never disappearing center. The keeping qualities of this flower are very unusual and it is borne on very long, stiff stems. A profuse bloomer. 


\section{NEW CACTUS DAHLIAS \\ ORIGINATED BY GEO. L. STILLMAN}

Head of the Nation, No. 2209. The largest incurved, claw-shaped true cactus Dahlia in existence. I have grown this wonderful Dahlia in my garden perfectly natural, without any disbudding whatever, to measure nine inches in diameter. Think what can be done with this flower by disbudding. In color this Dahlia is purple with a magenta overcast. It makes a tall plant and is an exceedingly free bloomer. When permitted to grow and bloom naturally it presents a novel sight seldom seen in a Dahlia garden.

Price of bulbs or plants, $\$ 50.00$ each

Ad. Grayson, No. 2250. Hybrid Cactus. The color of this beautiful Dahlia is an old rose slightly shaded a silvery rose. The petals are somewhat twisting and the whole flower is of a most exquisite formation. One of the best and most attractive cut flower Dahlias with extra nice long stems.

Price, $\$ \mathbf{5 . 0 0}$

Bishop's Hat, No. 2023. Color, a light DuBarry. A full, large flower with long, curly petals.

Price, \$2.50

Black Pekin. Hybrid Cactus. Color, nearly black. A beautiful, large, full-centered Dahlia and very attractive. Price, $\$ 3.00$

Blazing Star, No. 891. Color is a bright rich carmine. An unusually good type of Cactus, but a rather small flower. However, it is a very early and attractive specimen.

Price, 50c.

Bridal Veil, No. 2020. Pure glistening white. The petals of this flower are folded nicely and points are twisted in such a unique form that it is easily the most beautiful white Cactus Dahlia I have ever seen. The flowers are large and stand erect on good stiff stems superior to any other white Cactus.

Price, $\$ 3.00$

Bull Moose, No. 338. Hybrid Cactus. Color of outer petals a beautiful shade of pinkish yellow. Petals slim and quite plentiful. Center petals changing to canary yellow. A good flower with long stems. Large size and a fine specimen. Free bloomer.

Price, $\$ 3.00$

Caroline Laffield, No. 1427. Hybrid Cactus. A beautiful large, light, canary yellow Cactus. Very large and full, measuring $7 \frac{1}{2}$ inches in diameter. Extra fine. Good length of stem. A splendid specimen.

Price, $\$ \mathbf{2 . 0 0}$

Carrie Hammond, No. 890. Deep pink shaded yellow at base. The petals are finely rolled and twisted.

Price, 50c.

Caruso, No. 2132. Hybrid Cactus. This mammoth flower is certainly a wonder. The color is yellow, pink and salmon blended together in a most unique manner. The formation of this Dahlia is extremely beautiful and is a very deep, heavy flower.

Price, $\$ 10.00$
Christy Hoxie, No. 1436. Color, pale pink. Good formed flower on good stems.

Price, $\$ 1.50$

Clawfish, No. 430. Deep carmine. Good size flower and a finely formed Cactus.

Price, $\$ 1.00$

Cuba Ward, No. 640. Medium carmine Petals broad and sharp pointed and lightly tipped yellow and slightly yellow at base. A beautiful flower and most attractive.

Price, $\$ 1.50$

Dr. Walter Van Fleet, No. 2538. Hy. Cactus. Color, beautiful deep rose pink. Inner petals clouded light cream. The whole Dahlia presents shadings of the Dr. Van Fleet rose. A massive flower with twisting petals. A tall plant.

Price, $\$ 15.00$

E. P. Thompson, No. 505. Light velvety cardinal. Petals small and rolling. Large flower and extra fine form. Price, $\$ 2.00$

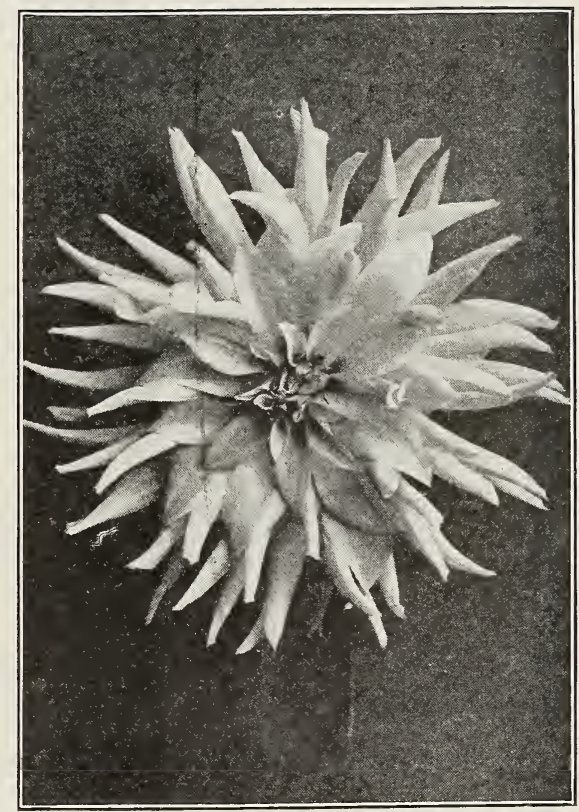

LADY EVELYN 


\section{NEW CACTUS DAHLIAS-Continued}

Eldorado, No. 2546. Hy. Cactus. Color, pure canary yellow while each petal has a small hair-like petal at its base which is nearly white in color. This is a medium size flower but is very desirable.

Price, $\$ 2.00$

F. Earl James, No. 242. Color, deep mottled cerise pink. This flower is very large and finely formed, of Hybrid Cactus type. Petals are very curly and twisted and some turn backward. The whole flower is most beautiful and makes an exceedingly pleasing effect.

Price, $\$ 3.00$

F. L. Deery, No. 306. A Dahlia made up of numerous, finely formed, pointed petals of Cactus type. It is a lovely lavender pink blotched through the fine petals and in some instances tiny spots of the coloring appear like the head of a pin. The pale lavender is clearer at very tips. Yellow shows very slightly at center. A fine size. The long, stout stems hold the Dahlia very erect.

Price, $\$ 1.50$

Geo. L. Stillman, No. 67. The color of this beautiful new Cactus Dahlia is a very rich, velvety, deep carmine. The form is exquisite, while in size it is a mammoth, having been grown to measure 11 inches across with stems 26 and 31 inches long. It has been grown in all climates. It bears its originator's name and has won prizes everywhere.

Price, $\$ 3.00$

Hollyhock, No. 2409. Hy. Cactus. Color, a nice salmon pink. Inner petals shaded yellow at base. A nice full center.

Price, $\$ 3.00$

Honey Dew, No. 2383. Hy. Cactus. Color, a beautiful salmon pink. Petals stand up in good shape and present a fine appearance. A fine addition to any garden.

Price, $\$ 2.50$

King Tom, No. 2003. Pure deep rose. This is a Hybrid Cactus Dahlia of very large size and a beautiful color. The petals are long and fold back to a long, sharp point. The whole flower much resembles Lady Helen except in color and is borne on good long stiff stems.

Price, $\$ 5.00$

League of Nations, No. 908. The color is a most beautiful shade of canary-yellow. In size it is the largest Cactus Dahlia yet produced. The stems on which the flowers are borne are very long and heavy, holding the mammoth flower quite erect. The keeping quality of this Dahlia has proven the past season to be wonderful, while its beauty has attracted much attention from visitors.

Price, $\$ \mathbf{5 . 0 0}$

Lady Helen, No. 217. A beautiful Hybrid Cactus Dahlia as distinctly new in quality and excellence as in origin; standing erect on long stems with finely formed and curled petals spreading out, making a diameter varying from $7 \frac{1}{2}$ to $8 \%$ inches. It is a striking and beautiful toned pink in the main body coloring, with slight veins of white, almost cream, running through the petals. Prominent cream tips make a decidedly new and altogether forcible addition to the whole flower. The Dahlia should be seen to be fully appreciated, for words of pen cannot do it justice. A profuse bloomer.

Price, $\$ 3.00$

Lieut. Joe, No. 800. Color, medium carmine. Petals bordered with a light vermilion. A very beautiful Dahlia.

Price, $\$ 1.50$

Mastodon, No. 822. Color, bright medium carmine. Petals slim and very twisting, standing in an upright and somewhat claw-shaped position. Extra large Cactus Dahlia of good form.

Price, $\$ 3.00$

Mrs. Aaron Ward, No. 723. A new Dahlia of unusual merit. The color is of a light reddish shade, veined and tipped yellow. The petals are very slim and curling, twisting in a very attractive manner. The Dahlia itself is very large and should be in every home garden.

Price, $\$ \mathbf{3 . 0 0}$

Mt. Shasta, No. 268. Hybrid Cactus. Very light shell pink with slightly deeper shadings of pink through the petals. A faint tinge of yellow shows toward center. Petals, long, slim and rolled at points. An extra fine, full, deep flower and enormous size. This flower when grown to perfection is simply a wonder in size, shape and color. Stands very erect on good, stout stems.

Price, $\$ 2.00$

New England Beauty, No. 2198. Hybrid Cactus. Color, a medium carmine red. A very large flower with a good center and a fine form. Very desirable Dahlia in any garden. Price, $\$ 5.00$

Orange Jelly, No. 2219. Hybrid Cactus. Color, pure canary yellow. A nice, lovely flower and beautiful color. This Dahlia is borne on good stems.

Price, $\$ 5.00$

Queen Josephine, No. 519. A handsome Cactus Dahlia of light butter yellow shaded to light pink at points. Petals are quite incurved. A good sized flower and very attractive.

Price, 50 c

Rosa Bonheur, No. 669. Hybrid Cactus. Dark scarlet. Petals quite broadened out and rolled to a point at tips. Price, $\$ \mathbf{1 . 0 0}$

Silver Lace, No. 2447. Hy. Cactus. Color, bright carmine red with each petal tipped white nearly to the base. A very large bright attractive flower and can only be appreciated when seen.

Price, $\$ 5.00$

The Royal Peach, No. 2113. Hy. Cactus. The color of this wonderful Dahlia is a deep peach pink. The petals are slightly shaded yellow toward the tips. The blossoms are very large and are borne on good stems. This is truly a wonderful color. A desirable Dahlia in every way.

Price, $\$ 3.00$ 


\section{NEW CACTUS DAHLIAS-Continued}

Tiger Rose, No. 2534. Hy. Cactus. Color, beautiful flesh pink. Inner petals light yellow and all tipped old rose. A most beautiful flower.

Price, $\$ 5.00$

The U. S. A., No. 749. The color of this exquisite, new mammoth Dahlia is a deep orange, that very unusual color so hard to get in a Dahlia. The formation as well as the color is so unique and novel that to attempt to describe it accurately would be an impossibility. It is a very free blooming Dahlia.

Price, $\$ 3.00$

Wonder of Nature, No. 2050. Hybrid Cactus of medium size. This wonderful Dahlia presents the most gorgeous array of beautiful flowers on the one plant of any
Dahlia that has ever come to my notice. The flowers are of a beautiful formation and are borne profusely on nice stems for cutting. Some of the blossoms possess the five shades that these flowers are made up of, viz: canary yellow, deep salmon, light salmon. pink and white. No person can accurately judge the beauty of this wonderful Dahlia by any description that can be put on paper. Hundreds of people who visited my fields and saw this Dahlia truthfully expresses it when they called it a real wonder.

Price, $\$ 2.00$

Yuletide, No. 2080. Pure glistening white, a very large flower with a full center. Petals are slightly curled and twisted. A gorgeous white.

Price, $\$ 5.00$

\section{ADDITIONAL NEW PIEONY-FLOWERED DAHLIAS}

\section{ORIGINATED BY GEO. L. STILLMAN}

The following new Paeony-flowered Dahlias were all recently originated by me after the most expensive and exhaustive experimental trials.

My original "New Dahlias" can truthfully be termed the best and most wonderful collection of elegant mammoth Dahlias in America.

The whole lot is made up of the most unusual gorgeous colors ever brought out in Dahlias.

Ad. Dewey, No. 413. Crushed strawberry. Canary yellow at base, slightly clouded through center yellow. Tips yeilow. A very large, full flower on very long stems measuring at time 16 inches. Price, $50 \mathrm{c}$

Adele, No. 1416. Beautiful canary yellow. Petals broad, slightly twisting. Numerous small, curly petals around center. Very good specimen and very free bloomer.

Price, 25c.

Afterglow, No. 2154. The color of this beautiful Dahlia is light orange. The petals are broad; the center ones stand up slightly giving the flower a very fluffy appearance. A very large Dahlia with a very desirable color. Should be seen to be appreciated. Price, $\$ 3.00$

Alaska, No. 935. Pure glistening white with quite broad, slightly rolling florets and numerous small curly petals around disc. The flower is borne on long jointed stems and a very good Dahlia for cut flower purposes.

Price, $\$ 2.00$

Alleghany Mt., No. 2520. Color, deep velvety carmine with outer half of petals pure white, while lines of carmine run nearly to tip of the inner petals. This is a nicely formed flower and one of the most beautiful Dahlias imaginable. A bright and shining light in the Dahlia garden.

Price, $\$ \mathbf{2 5 . 0 0}$

Alpena, No. 793. Red shaded cerise, slightly tipped yellow. Base of petals heavily colored yellow. Blooms stand erect on stiff stems.
Alys, L. VI. Color, bright carmine, heavily clouded yellow. A beautiful flower of very large size. Tips of some flowers are yellow. A prize in any garden. Price, $\$ 3.00$

Amber Queen, No. 1120. Golden amber. Flowers are of good size and with quite broad, flat petals. A most desirable Dahlia of fine form. Price, 35c.

American Hero, No. 963. A most wonderful Paeony-flowered Dahlia. The color is difficult to describe accurately. The center of the florets is a beautiful shade of old rose, outer edges are bordered with light pink. The disc is surrounded with numerous small, curly florets possessing the same beautiful shades of pink. The whole flower possesses the most striking and desirable colors yet produced in a Dahlia. It has good stems which hold these beautiful flowers very erect.

Price, $\$ 1.50$

Augusta, No. 2175. The color of this Dahlia is a bright medium shade of carmine red. This is a very large flower and is borne on nice extra long stems. One of the very best reds.

Price, $\$ 3.00$

Aunt Basha, No. 296. Color, deep velvety maroon. Flowers very full and fluffy. Petals cup and roll the whole length with age. The most dazzling dark maroon flower yet seen. Splendid for cutting, with long stems, and a good sized flower.

Price, $75 c$.

Aurea, No. 2161. Color, light salmon pink. A most desirable color and a very attractive flower. Inner petals slightly clouded yellow at base. Price, $\$ \mathbf{3 . 0 0}$ 


\section{ADDITIONAL NEW PAEONY-FLOWERED DAHLIAS-Continued}

Autumn, No. 1017. Color, clear, light velvety carmine. A large, full flower with numerous petals which are quite pointed and twisted at tips. A very free bloomer and a most desirable flower. Price, 50c.

Avanella, No. 284. Color, a beautiful shade of pink. A large flower, very full and compact. This Dahlia won first prize for largest flower in the Hartford, Conn. Show. The color and form of this Dahlia are superb.

Price, $\$ 2.00$

Bellflower, No. 937. Color, light pink. Petals slightly clouded white on face side, reverse side much darker. A very free bloomer and attractive Dahlia. Price, $\$ \mathbf{1 . 0 0}$

Betty Dukane, No. 286. Velvety carmine and crimson, streaked and splashed with yellow from base to center of petals. Reverse side of petals very much lighter. Flower is very full and heavy with long, quite slim petals which are rolled and slightly twisted at points. A very desirable flower with heavy, stiff stems.

Price, $\$ \mathbf{2 . 0 0}$

Big Ben, No. 2068. Color, medium deep carmine. A very large heavy flower carried on long, heavy stems. One of those good shades of red.

Price, $\$ \mathbf{2 . 0 0}$

Blood Stain, No. 2011. Pure white with edges of petals deep rich carmine at the base, balance of petals pure white. The flower has the appearance of having been stained near the base with blood. A beautiful flower.

Price, $\$ \mathbf{2 . 0 0}$

Bonfire, No. 2149. The color is bright scarlet. The formation of this flower is quite flat, but full. A very attractive, bright color. The blossom is an extra large one.

Price, $\$ 2.50$

Butterfly, No. 2034. Color, a beautiful light orange. This is a very large flower of a true Paeony type. It is truly a prize in any garden.

Price, $\$ 3.00$

Charlotte Laverne, No. 940. The color of this beautiful flower is a light, chrome orange, while the reverse sides of the petals are a salmon pink. The petals fold back to a long, sharp point giving the flower a curly effect together with its numerous small curly petals around the disc.

Price, \$2.00

Cardinal Mercier, No. 910. The color of this new, mammoth Dahlia is a deep flesh pink with slight veins of canary shooting up from the base of the petals in the center. Then there appears a glistening silvery sheen of the white flesh peach. The curly formation of the florets of this beautiful flower is indeed remarkable. In size and form there are very few flowers of its equal. Many of them measure without disbudding 9 and 10 inches across.

Price, $\$ 5.00$

Celestial, No. 2350. A waxy white slightly overcast with pink on half of petals at base. Outer petals fold forward and lie straight while center petals are curly and twisting more or less. Price, $\$ \mathbf{3 . 0 0}$

Cherry Pie, No. 2092. In color this flower is a light pink. Petals quite broad and pointed at tips. A beautiful color and an attractive flower.

Cinabar No. 707. The color of this Dahlia is a deep, velvety, rich carmine, with darker and lighter streaks running through the petals. A beautiful flower and of nice formation.

Price, 75c.

Clara Lambert, No. 1313. Face of petals purple magenta at points, shading to white at center and base, resembling Philadelphia Paeony. Good size. Price, $\$ \mathbf{1 . 0 0}$

Cloth of Gold, No. 2247. Color, light butter yellow. This is a mammoth flower with broad, nearly flat petals. The flowers are borne on extra long stems. Price, $\$ \mathbf{5 . 0 0}$

C. N. Landon, No. 292. Color, old gold or bronzy yellow. A very large flower of a beautiful type. The petals are very long and slim and incurved to a nearly upright position. A most attractive form and color.

Colonial Dame, No. 2201. Color, $\$ 1.00$ pink growing deeper at center. A nice flower and fine color.

Price, $\$ 3.00$

Cora L., No. 289. Color, a beautiful shade of light lavender. One of the most attractive colors for a Dahlia. A large-sized flower of extra fine form.

Price, $\$ 1.50$

Coral Beauty, No. 1035. Clear Coral. This wonderful new color for a Dahlia attracted the attention of all who visited the garden. The petals of the flower are broad and heavy, and show well above the foliage.

Price, 50c.

Corine R., No. 946. This is without doubt the largest pure white Paeony-flowered Dahlia yet produced. The florets are broad, curling and twisting, giving the flower a slightly fluffy appearance.

Price, $\$ 2.00$

Crackerjack, No. 2369. Color, pure white with each floret heavily bordered deep red or carmine. A very noticeable plant when in flower.

Price, $\$ 1.00$

Cumberland Mt., No. 2506. Color, light canary yellow. Petals fold forward a little and twist slightly at the tips. A mammoth flower on stiff stems and an unusually free bloomer.

Price, $\$ 10.00$

Curlycue, No. 2035. Deep reddish pink of the Paeony type. Petals very long and slim and lie flat. Center half of flower is very curly and twisting. The flower is large and a flat shape; also has a nice color. Price, $\$ \mathbf{2 . 0 0}$

Dana, No. 488. Color, light reddish buff shaded to red at center. Petals are rolling and curve slightly backward. Price, 75c.

David Harum, No. 1403. Beautiful shade of scarlet. Large flower and extremely bright. A good form.
Price, 50c. 


\section{ADDITIONAL NEW PAEONY-FLOWERED DAHLIAS-Continued}

Dazzler, No. 471. Medium shade of red shaded to canary yellow at base and clouded white at tips. Petals slightly rolled and twisted. Extra good stems for cutting.

Price, $\$ 1.00$

Donalda, No. 308. A béautiful shade of canary yellow. This is a large flower with long, slim, rolled petals, standing nearly upright. It is wonderfully attractive for the garden or exhibition table. Price, $\$ \mathbf{2 . 0 0}$

Dorothy Dewey, No. 446. Lemon yellow. Petals heavily shaded and bordered with pink. A very fine large, exquisitely formed flower and a fine shade.

Price, $\$ 1.50$

Dr. Robert Taylor, No. 608. Deep peach pink. Petals long and quite slim, rolled and twisted in various shapes. A most beautiful shade and a very free bloomer on fine stems.

Price, $\$ \mathbf{2 . 0 0}$

Dudley Palmer, No. 1122. A lovely salmon amber with broad, flat petals, curled enough to give the flower attraction. The petals are streaked and blended with a deeper shade of salmon, slightly more reddish. Smaller petals streaked in the same manner. are curled about the center. A very desirable good sized flower erect on strong stems,

Price, $\$ 1.00$

Earle Williams, No. 1339. Ruby, striped and shading to white and pink. Large flower and inner petals very curly, outer petals broad and pointed. Fine stem.

Price, $\$ \mathbf{2 . 0 0}$

Early Morn, No. 569. Lavender with a slight clouding of white. Petals slightly yellow at base. A nice shape and a very unusual combination of colors. Large size flower.

Price, $\$ 1.00$

Edith L., No. 2182. The color of this handsome Dahlia is a nice lavender pink overcast with a reddish shade. A very odd nice colored Dahlia on good stems. You should see this plant to appreciate it.

Price, $\$ 3.00$

Edna Daley, No. 2202. Color, pink with a slight lavender sheen. The formation of this flower is a true Paeony, the color is simply fine, and the size is large. Price, $\$ 3.00$

Eureka, No. 860. Color, deep pink. Petals long and roll forward. A heavy, deep flower of extra good formation. A fine attractive color.

Evening Belle, No. 2277. Color, light salmon, solid color. One of those delicate shades of salmon which is so pleasing to the eye. A large flower.

Price, $\$ 3.00$

Evening Star, No. 250. Color, light fiery red, heavily colored yellow at base of petals. Petals are flat, sharply pointed and slightly tipped yellow. A medium sized flower, but a beautiful combination of colors, and very attractive.

Price, $75 \mathrm{c}$.

Ezra Dalton, No. 149. Light straw, heavily clouded and veined with light red.

Price, $\$ 1.00$
Firebird, No. 1044. Bright red. Large sized flower of a very desirable color and full form. One of the bright colors that attract every one.

Price, 75 c.

Fire Girl, No. 156. Bright scarlet with heavy circle around the center of bright canary yellow. Petals are rolled and quite slim, sharp pointed and tipped yellow. Very showy and attractive. I was awarded a first-class certificate on this flower at N.Y. Horticultural Dahlia Show. Price, \$1.00

First of All, No. 2018. Color, light salmon or apricot yellow. A nice flower of large size. The blossoms are borne on long, stiff stems, good for cutting. Price, \$2.00

Florence C., No. 2217. Color, bright magenta heavily clouded white with heavy veins of white running through the petals. A beautiful combination of colors. A very showy flower.

Price, $\$ 2.50$

Ford Sterling, No. 1389. Very light pink with dashes of deep pink. This flower is a most desirable one. Price, 75c.

Frank Suplee, No. 2031. A Paeonyflowered Dahlia of a beautiful deep orange color. A large flower on good stems for cut flowers.

Price, $\$ \mathbf{2 . 0 0}$

Frizzy, No. 261. White and cerise blended together and yellow at base. Petals are of various sizes, small, sharp and twisted in various shapes. Plant is of low growth, medium size flowers and good length of stem.

F. X. Bushman, No. 1348. Pink with shading of yellow running through petals. Petals long and flat and curving backwards. Small, curly petals at center. Attractive combination of colors. Good size.

Price, $\$ 1.00$

General Appleton, No. 613. Deep pink, clouded light pink. A large, fine flower of exquisite colorings. $\quad$ Price, $\$ \mathbf{2 . 0 0}$

G. H. James, No. 263. Color, light cream with a very wavy appearance, while the reverse side of the petals is clouded cerise. Petals are broad and flat and taper abruptly at ends to a sharp point. This is one of the most unique beauties of the whole Dahlia family.

Price, $\$ 2.00$

Gentlemen Sir, No. 2363. Deep magenta with each petal heavily tipped white; some flowers produced are nearly solid magenta. A very showy, noticeable Dahlia. Flowers very large and velvety. Price, $\$ 3.00$

Golden Feather, No. 919. This Paeonyflowered Dahlia is of an unusually golden yellow mixed with a slight shading of pink. The florets are quite broad and pointed at the tip. A beautiful formation. Price, $\$ 3.00$

Golden Orange, No. 924. The color of this Dahlia is a beautiful golden yellow clouded and heavily tinted with orange. Its long, slim petals and twisting shape make the formation of the Dahlia unusually beautiful. Price, \$2.00 


\section{ADDITIONAL NEW PAEONY-FLOWERED DAHLIAS-Continued}

Golden Sun, No. 798. Color, rich old gold. The petals of this flower stand up and are slightly rolled. A very showy flower and quite tall growing.

Price, $\$ 2.00$

Grand Malta, No. 2230. Color, a medium carmine heavily clouded and tipped yellow. A bright showy flower of Geisha colors, but an entirely differently formed flower and much better for cutting.

Price, $\$ 2.00$

Happy Thought, No. 2067. Color, a deep purple. Petals heavily tipped white while quite a few of the flowers come solid purple. A large flower with wide petals. Both flowers solid or variegated, are very attractive.

Price, $\$ 3.00$

Harry McCoy, No. 1336. Light, clear, canary yellow. Back of petals very curly at center and slightly rolled forward. A good shaped Paeony. Long stems. Price, \$1.00

Helen of Troy, No. 768. Color, a beautiful shade of light orange. This flower is not very full, but a first-class Dahlia for cut flowers and a very desirable color.

Price, $\$ 2.00$

Henry Clews, No. 410. Go den amber. Petals broad and pointed. Slightly twisted and curled around center. Three to four rows of petals.

Price, $\$ 1.50$

Icabod, No. 277. Light cream, heavily clouded cerise. Petals narrow, numerous and very curly and twisted. Price, $\$ \mathbf{2 . 0 0}$

Ideal, No. 2222. Color, a nice salmon yellow. A fluffy flower with twisting petals forming a fine flower.

Price, $\$ 3.00$

Irish Cobbler, No. 914. Color, reddish brown salmon clouded slightly yellow in the center of flower. This is one of the very ordinary yet desirable colors. An unusually large flower.

Price, $\$ 5.00$

Irva Varrelman, No. 816. The color of this beautiful flower is white, shaded to a light cream at base of petals. It should be seen to be thoroughly appreciated. The flower is large and the colors are so pure and clean that it cannot fail to please the most critical eye. Flowers are produced very freely and on good stems for cutting. It should be in every Dahlia collection.

Price, $\$ 2.00$

Isabelle, No. 1003. Large flower. Petals pinkish red shaded to yellow at base. Petals around center curled and twisted. Extra long stęms.

Price, 50c.

J. Austin Shaw, No. 1306. Beautiful Paeony of peach yellow. Each petal heavily veined with two lines of pink. Petals slim and pointed and heavily clouded pink. An attractive flower with extra good items for cutting

Price, 75c.
Jane Witherspoon, No. 2126. The color is medium carmine. Each petal being heavily clouded canary at the tips. A very showy flower of good size.

Price, $\$ 3.00$

Jean Andersoin, No. 1118. Salmon buff slightly clouded with deep yellow. The style of this flower is very unique, with its small twisting petals around the center and the curly features of the larger ones. One of the entirely new shades.

Price, $\$ 1.00$

Jennie Lind, No. 2379. Color, red salmon; one of those nice rich shades of salmon so desirable.

Price, $\$ 2.00$

Jim Dandy, No. 117. Very rich velvety magneta. Base of petals is yellow and white, forming a circle $1 \frac{1}{2}$ inches in diameter. The petals are sharp, pointed and heavily tipped and veined with white. The brightest combination of colors imaginable.

Price, $\$ 1.00$

John Churchill, No. 478. Red salmon pink, or nearly peach pink. Petals broad and twisting. A beautiful flower in every way.

Price, $\$ \mathbf{1 . 0 0}$

Joseph's Coat, No. 1002-A. Color, light red tipped white. It occasionally has a solid red blossom on the same plant with the tipped ones. This is a low plant and a good bloomer.

Price, $\$ 1.00$

Josh Billings, No. 254. Purple. Petals flat, points sharp and twisted. Flowers medium size, but good stems. Desirable.

Price, 75c.

June, No. 619. Peach pink, clouded and streaked with gold at base of petals. A fine large flower on long stems. Very graceful for house decoration and a superb color.

Price, $\$ 3.00$

King Saul, No. 729. Color, very bright rich carmine, a very heavy, deep flower and solid color. This is one of the most beautiful shades in red that can be found in the whole Dahlia family. The flower is good size and of nice formation. Price, $\$ \mathbf{1 . 5 0}$

Kinney. Color, a beautiful shade of pink, growing lighter in center. Petals slightly twisted, making a fine shaped flower.

Price, $\$ \mathbf{1 . 5 0}$

Kit Carson, No. 444. Deep pink shaded lighter at points. Center petals beautifully rolled and curled. A large flower. Price, \$1.50

Klondyke, No. 760 . Color, reddish apricot shaded to yellow in center. Center petals quite curly and good Paeony form.

Price, $\$ 1.50$

Lady Astor. Purple and carmine: Petals roll back and are heavily tipped white. A good size flower and very showy on long stems. 


\section{ADDITIONAL NEW PAEONY-FLOWERED DAHLIAS-Continued}

Lady Derby, No. 2189. Color, pure white with florets clouded on the edges with bright red. An ideal Paeony Dahlia, large and very showy. You should see Lady Derby.

Price, $\$ 5.00$

Lady Winnifred. A large, full, yellow Dahlia, with petals curving and twisting in a pretty manner. The outer petals are faced underneath with a beautiful shade of pink which gradually becomes lighter toward the center.

Price, $\$ 3.00$

Lake Trout, No. 2456. Color, a very red salmon, very near a cherry shade which is a beautiful but odd color. This is a very attractive Dahlia and is held erect on long stems. You should catch a Lake Trout.

Price, $\$ 2.50$

Lemon Pie, No. 2266. Color, pure canary yellow. A nice flower of good size and color. The flowers have long stems.

Price, $\$ 2.00$

Livermore, No. 2108. Light butter yellow. Petals of this Dahlia are quite broad and slightly twisting, being shaded pink at outer half. A very large flower and has good stems.

Price, $\$ 1.50$

Lord Beaconsfield. Bright carmine with petals havily tipped white while some are more red than others. A big deep flower on long stems.

Los Angeles, No. 245. Color, white, heavily clouded cerise. Some of the petals almost white. The flower is large and has broad, flat petals, giving it a very decorative effect. A beauty. Price, $\$ \mathbf{1 . 0 0}$

Luxury, No. 2231. Color, a beautiful light purple. A heavy, large flower with nice curly petals which give this Dahlia a very striking appearance.

Price, $\$ 3.00$

Mabel Martin, No. 1323. Bright cerise or phlox, heavily clouded and striped white. Petals long and slim. Medium size, with long stems.

Price, $\$ \mathbf{1 . 0 0}$

Mainland, No. 2141. Color deep magenta clouded lighter. Petals roll forward in center. A very odd color and tall plant.

Price, $\$ 1.50$

Marguerite Clark, No. 248. Color, very light cream on face of petals which are curled and twisted in fine shape. The reverse side of petals is heavily clouded cerise pink, which gives the flower a beautiful variation of colors. Large size.

Price, $\$ 3.00$

Marie Doro, No. 152. Color, light cardinal slightly clouded white at tips. Petals very curly and twisted of an unusual formation. Extra fine stems.

Price, $\$ 1.00$

Marie Suplee, No. 936. The color of this beautiful Dahlia is a deep butter yellow with long, slim, twisting florets. A true Paeony-flowered specimen borne on. good stems. One of the most beautiful yellow Paeony-flowered Dahlias yet produced.

Price, $\$ \mathbf{2 . 0 0}$
Mark Twain, No. 298. Very light, bright red with heavy circle of yellow around disc much like Evening Star. Petals pointed and very twisting. A beautiful showy flower.

Price, $\$ \mathbf{2 . 0 0}$

Market Surprise, No. 2098. Color, light magenta shaded lighter at base of florets. Petals very broad and long white center ones are quite twisting. A beautiful large flower.

Price, $\$ 2.00$

Mary Evelyn, No. 2243. This flower is made up of several shades of salmon which are very striking. Reverse side of petals is nearly red. A beautiful large flower on good strong long stems.

Price, $\$ 5.00$

Ming Toy, No. 2227. Color, rose pink shaded lighter at tips of florets which slightly fold forward. A nice color in any decoration.

Price, $\$ \mathbf{2 . 5 0}$

Maud Tripp, No. 250-D. The color and shape of this Dahlia are both novel. The flower is very large, with long, slim, rolled petals, standing up and incurved in a pleasing manner. The color is a purple lavender with lines of yellow whole length of petals. The flowers vary somewhat in shade.

Price, $\$ \mathbf{1 . 0 0}$

Mildred Lanphear, No. 844. The color of this Paeony-flowered Dahlia is a very light pink. The formation is beautiful with numerous curly petals in the center. A fine flower for cutting and produced on long stems.

Price, $\$ 1.00$

Mina Davis, No. 603. Bright orange, heavily veined and clouded yellow, giving the flower a bright orange shade; a very nice, peculiar color. Petals are quite broad, but well shaped.

Price, $\$ \mathbf{1 . 5 0}$

Minnie Foster, No. 2061. Tan or straw very closely describes the general color of this beautiful Paeony-flowered Dahlia. The flowers are very large and borne on long stems. Petals are quite broad and slightly fluffy with nice curly petals in center. A very unusual shade has this Dahlia.

Price, $\$ \mathbf{2 . 0 0}$

Mock Orange, No. 2086. Color of this flower is a light canary yellow, shaded just enough with pink to give it a beautiful, attractive, and rather unusual color. A fine Dahlia for cut flowers.

Price, $\$ \mathbf{2 . 0 0}$

Most Popular, No. 2261. Color, butter yellow. A very large flower with petals which are quite broad and flat. Very much resenbles the Billionaire. Price, $\$ 3.00$

Montana, No. 827. Light chrome orange, with cloudings of pink and salmon. The Montana is one of those flowers that with a very little extra care and disbudding there Is almost no limit to its size and beauty. It has fine stems for cutting and can be used with hundreds of other colors. Price, $\$ \mathbf{2 . 0 0}$ 


\section{ADDITIONAL NEW PAEONY-FLOWERED DAHLIAS-Continued}

Morning Light, No. 735. A clear canary yellow, Paeony-flowered Dahlia with long, slim petals. The shape of this Dahlia is much like a Decorative and quite full.

Price, $\$ 2.00$

Mrs. A. J. Moulton, No. 610. A beautiful shade of golden orange changing to canary at base of petals. Petals are broad and slightly rolled, giving the flower a fluffy appearance. Reverse side of petals is a red salmon, which shows on the face where the petals are rolled.

Price, $\$ 3.00$

Mrs. E. G. Layng. Color, pink and yellow, striped and clouded together, making a very showy flower. It is a very large flower on good stems.

Price, $\$ \mathbf{2 . 0 0}$

Mrs. Rockwell, No. 1048. Deep, rich cardinal. A large flower of an unusually rich color. This Dahlia should be seen to be appreciated. The flowers are borne on good stems well above the foliage and are very showy and attractive.

Price, $50 \mathrm{c}$.

Mrs. Wm. F. Lyons, No. 2533. Color, deep canary yellow. The petals which are narrow and fold forward, are shaded pink on the back side. A very large flower and good color.

Mt. Vernon, No. 2212. Color, bright, light carmine. A heavy flower of immense size with rich, bright color. The florets of this flower are very broad and heavy.

Price, $\$ 3.00$

Naomi, No. 941. This Paeony-flowered Dahlia is very large in size. A rich orange color with a reddish cast; florets are faintly bordered with a reddish shade. With fairly good treatment this Dahlia is certainly a mammoth.

Price, \$3.00

Neapolitan, No. 2215. Color, a light purple while each petal is bordered with light purple or deep lavender. A very attractive, large flower on good branching stems.

Price, $\$ 3.00$

Nora Belle, No. 18. Very light yellow, heavily clouded cerise. Petals curl backward and very much twisted.

Price, $\$ \mathbf{2 . 0 0}$

Old Homestead, No. 2192. Color of this flower is hard to describe; it is a deep, reddish peach pink and simply rich and most striking. It is of immense size and is borne on good stems. A very desirable Dahlia for any garden.

Price, $\$ 3.00$

Orange Reliance, No. 990. Color, a very delicate orange buff. Broad florets which are very pointed at the tips which are serrated in saw-tooth-shape. A very attractive color. Ostrich Plume, No. 507. Color, yellow heavily veined and clouded red. Price, $\$ 1.00$

Over-the-Top, No. 921. This new Paeony-flowered Dahlia is truly a mammoth and of a very unusual color, being a deep rose lavender as near as can be described. Some people have called it pure rose, others a lavender pink. However, it is a wonderful flower in every way, size, color, formation, and its free blooming qualities are unsurpassed. Price, $\$ \mathbf{2 . 0 0}$

Ozark Mt., No. 2503. Color butter yeilow, each petal slightly striped with red. A nicely formed and very large flower of unusual merit.

Price, $\$ 10.00$

Peach Perfection, No. 978. The color of this beautiful Dahlia is a deep peach pink tinted slightly with yellow at the base. Florets are quite broad and pointed at the tips giving it a fine attractive appearance. A most unusual and desirable flower.

Price, $\$ 3.00$

Philmena. Very light pink shading to almost white. Very large deep flower of exquisite form and color. Price, $\$ \mathbf{5 . 0 0}$

Pink Jewell, No. 2040. The color of this flower is a beautiful light pink. Petals broad, nearly flat. This is a very delicate shade of pink and a very desirable flower for the home garden.

Price, $\$ 2.00$

Pink Wonder, No. 2173. Color a beautiful shade of deep pink. This massive pink flower should be seen to be appreciated. It has good stems and is worthy of a place in any garden.

Price, $\$ \mathbf{5 . 0 0}$

Pinkie, No. 2152. Color, light flesh pink. One of those nice shades of pink so desirable in a Dahlia.

Price, $\$ 3.00$

Policy, No. 2530. Color, canary yellow and pink, clouded together with yellow predominating. The slightly twisting petals fold both forward and backward. An immense lot of curly petals are in the center of the flower.

Price, $\$ \mathbf{2 . 0 0}$

Prosper, No. 754. Color, apricot yellow, shading of light butter yellow at base. Each petal is serrated, forming a three saw-tooth tip. A very desirable color. Price, 75c.

Purple Monster, No. 859. The color of this monster Dahlia is a very deep velvety purple. The formation of the flower is exquisite and it is borne on very long stems. It is certainly a mammoth. Price, $\mathbf{\$ 1 . 5 0}$

Purple Morning, No. 2566. Color, deep lilac, or light purple. Petals fold forward, but stand straight out. A unique color.

Price, $\$ \mathbf{2 . 0 0}$

Pussy Willow, No. 968. A very desirable shade of medium yellow. The flower is formed of broad twisting petals and is borne on good stems for cutting. Price, $\$ \mathbf{1 . 5 0}$

Queen of Pinks, No. 2228. Color, a beautiful pink slightly shaded lighter at tips and showing a slight overcast of lavender. A true Paeony type and a lovely flower in every way. If you will add the Queen of Pinks to your collection you make a move in the right direction.

Price, $\$ 3.00$

Radaint Charming, No. 161. White heavily clouded deep pink. A beautiful flower for cutting on long stems. Good size,

Price, 50c. 


\section{ADDITIONAL NEW PAEONY-FLOWERED DAHLIAS-Continued}

Red Dawn, No. 930. Color, dark, rich maroon. A very large flower of a rather unusual formation, the florets being very long and pointed, giving it an extremely flne appearance.

Price, $\$ 1.50$

Red Helmet, No. 922. Dark velvety carmine. The florets of this Dahlia are very broad and twisting tapering to sharp points at the tips. A large flower on good stems.

Price, $\$ \mathbf{1 . 5 0}$

Rhode Island, No. 2010. Pure white and each petal bordered with very light red (almost a yellow) and the tips of petals are white. This is a medium size Paeony-flowered Dahlia on extra good stems which hold the flower erect. An extra good cut flower sort, very desirable, and very attractive in color.

Price, $\$ 5.00$

R-34, No. 927. A mammoth Paeony flowered Dahlia of a golden salmon shade. In size and formation this Dahlia is wonderful. The flower, which is borne on long stems, is extremely large; colorings unusually attractive.

Price, $\$ 1.50$

Rienette, No. 358. Magenta and white beautifully blended together. Two heavy veins of white run whole length of petals. Base slightly tinted yellow. Price, 50c.

Rosy Blonde, No. 945. Color, deep salmon tinted with yellow at base of florets. Much resembling Jean Anderson, but with florets more twisting and a darker shade of orange. A fine cut flower Dahlia.

Price, $\$ 1.50$

Rosy Morn, 796. Color, old rose pink. One of the finest colors in Dahlias. Long stems and flowers stand up; good for cutting.

Price, $\$ 1.00$

Ruth Thompson, No. 2263. Color, a reddish salmon and yellow clouded together in a most beautiful manner. A very large flower and fine for cutting. Price, $\$ 5.00$

Salmon Boy, No. 2301. Color, red salmon. The reverse side of petals are a deeper shade which gives the flower a nice combination of colors. The florets are finely pointed while the center is surrounded by lots of curly ones. A beautiful flower and very large.

Price, $\$ \mathbf{5 . 0 0}$

Sayoy, No. 2170. The colcr of this beautiful large Dahlia is a light lavender. It is a finely formed flower and has extra long stems for cutting.

Price, $\$ \mathbf{2 . 5 0}$

Sleepy Hollow, No. 2545. Color, bright light orange. The reverse side of petals are a burnt orange which gives the flower a unique appearance. The petals are long and fold forward.

Price, $\$ \mathbf{3 . 0 0}$

Shellflower, No. 960. The color of the outer petals of this flower is light lavender while the center ones are white. The petals are slim and twisting to a point. An unusually attractive flower.
Silverine, No. 93. White, clouded and veined pink. Good flower on long stems.

Price, $75 c$.

Si Perkins, No. 499. This flower presents a brindle appearance. Having a mixture of red and white, also a tint of yellow shows quite prominently. Rather an odd combination of colors, but an attractive flower.

$$
\text { Price, 50c. }
$$

Sir Galahad, No. 346. Carmine, heavily blended with bronze yellow. The combination of colors in this flower is very striking. It might well be termed a "Brindle Giant Curio."

Price, $\$ 2.00$

Sister Jane, No. 437. Clear, light canary yellow, good sized flowers, true Paeony style with petals curled and pointed in artistic manner. Splendid, long, stiff stems hold it very erect. Price, $\$ 1.00$

Society, No. 2089. Canary yellow heavily clouded light red. A very showy and attractive flower.

Price, $\$ 1.50$

Spencer Marsh, No. 2235. Color, deep velvety carmine. A very large flower of a beautiful shade of carmine. The petals are well folded and are of a twisting formation.

Price, $\$ 5.00$

Spring Maid, No. 2244. Color of this Dahlia is unusual, being a light purple, lilac or deep mauve. A good size and well formed flower.

Price, $\$ 2.50$

Sunflower Gem, No. 642. This striking, new Paeony-flowered Dahlia is simply a wonder in the Dahlia family. The close resemblance of this flower to the Sunflower is very remarkable. The large open center, or disc, is especially beautiful. The flower itself is borne on long, stiff stems and is held in an upright position, making one of the most attractive of the Paeony-flowered Dahlias.

Price, $\$ 1.50$

Sweetheart, No. 2116. The color is light red. Each petal is heavily tipped white. The twisting formation of the petals of this flower give it a very attractive appearance.

Price, $\$ 3.00$

Speaker of the House, No. 2330. Color, deep purple with each petal heavily tipped white. This wonderful Dahlia makes the most showy plant in my whole collection with one exception. The flowers are very large and uniformly marked, and with the great contrast in the colors it is a very noticeable plant among the others. Therefore, it can be easily termed "The Speaker of the House."

Price, $\$ 10.00$

Stillman's Red Cross, No. 1412. Bright deep carmine. Petals quite long and fluffy. Solid color. Large size flower. Fine stems for cutting.

Price, $\$ 1.00$

Thanatopsis, No. 794. Color, red, shaded pink and base of petals yellow. A fine cut flower Dạhlia.

Price, $\$ 1.50$ 


\section{ADDITIONAL NEW PAEONY-FLOWERED DAHLIAS-Continued}

The Billionaire, No. 552. Another monster Dahilia to class up with the "Millionaire" which I introduced. The color is a beautiful shade of golden orange. Though the Billionaire is an entirely different style of flower it is fully equal to the Millionaire in its own family. It is simply a wonderful production. The color is wonderful, the shape is wonderful, the stems are wonderful, and the plant itself is wonderful. The plant making a low growth and the flowers being of an immense size, produced on extra long stems, and being profuse bloomer gives the plant a most beautiful appearance and makes it surely a wonder. It should occupy a place in your garden.

Price, $\$ 2.50$

The Camouflage, No. 870. Color, carmine heavily tinted yellow. Yellow mixed with the carmine. A very desirable flower.

Price, $\$ 1.50$

The Colored Jockey, No. 2208. Color, deep maroon and clouded magenta. Petals wide and rolled to a sharp point. The reverse side of petals are a light pink. A very unusual flower and one which attracts the notice of all visitors to the garden.

The Heroine, No. 650. Velvety $\$ 3.00$ genta, heavily veined and clouded light pink. A mammoth flower with an elegant combination of colors.

Price, $\$ 5.00$

The Royal Mayor, No. 594. Light butter yellow. Petals long, slim and rolled. Lots of smaller petals twisted and curled around center in a unique form. A large, fine colored flower of unusually fine appearance.

Price, $\$ 3.00$

Thesens. Color, a beautiful shade of salmon pink. A monster flower and of a most lovely color. A Thesens would be a fine addition to any garden. Price, $\$ 5.00$

Thomy Thompson, No. 239. Color, a shaded golden salmon. A large, beautifully formed flower with long, slim, curly petals. It is a very large, full, deep flower and of unusual quality.

Price, $\$ 2.00$

Thos. Galvin, No. 411. Body old gold, slightly shaded pink. A deep heavy fluffy flower. Petals broad and long and twisting. The reverse side of petals clouded pink and showing from the front where the petals roll up. A wonderfully fine, mammoth, new Dahlia. $\quad$ Price, $\$ 2.00$

Thyme, No. 2168. Color, magenta clouded and veined white. A very showy flower and one that attracts the eye of all.

Price, \$2.50

Tip Top, No. 1004-A. Light salmon and florets slightly bordered pink with numerous small curly florets at the base. The flower is good size and of exquisite formation.

Verna Thompson, No. 77. White, heavily clouded cerise. This immense, large new Paeony Dahlia is a beauty beyond all doubt. It closely resembles Aunt Electa in color, but somewhat different in shape. A very full deep flower. $\quad$ Price, $\$ \mathbf{1 . 0 0}$

Victor Herbert, No. 1302. Purple. Pet-. als quite long and slim and of a perpendicular shape, also incurving. A fine flower.

Price $\$ \mathbf{2 . 0 0}$

Westerly, No. 752. The color of this beautiful Dahlia, as near as can be described in general terms, is a deep, old rose with peach pink shading, a most unusual color and extremely attractive. The flower is of immense size and borne on extra long stems. I was awarded first prize on this Dahlia by the Mass. Hort. Society at their Dahlia Show in Boston, in September, where it was admired by everyone.

Price, $\$ \mathbf{2 . 0 0}$

W. F. Brown, No. 782. Color, yellow, red and deep pink, about equally divided in this beautiful Paeony-flowered Dahlia of various colors. This is a wonderful flower of exquisite formation. The petals are curling and twisting in fine shape and colors present a beautiful combination. It is one of the most free blooming Dahlias in the whole Dahlia family. Price, $\$ 3.00$

White Cap, No. 318. Pure white with broad, flat petals of a glittering appearance. This Dahlia is large and possesses qualities of great merit for house decorations, in bunches or vases.

Price, \$1.00

White Climax, No. 2037. Pure white with long, slim, twisting petals. A medium size flower and desirable. Price, \$1.50

White Dove, No. 470. Very pretty pure white Paeony. Petals small and slightly curled, giving fluffy appearance. Stems long. Slightly shaded light cream in center. Very full and unique. Price, 75c.

White Navy, No. 2336. Color, pure glistening white. The florets are quite numerous and are finely formed. A nice cut-flower variety on good stems. $\quad$ Price, $\mathbf{\$ 2 . 0 0}$

White Pearl, No. 995. Pure glistening white. The florets of this beautiful white Dahlia are broad and flat, standing out like those of a single Dahlia. The plant makes a low growth and the flowers stand up above the foliage in beautiful shape. When planted in a row the whole row has almost the effect of a snowbank. The profusion in which these beautiful white blossoms are displayed is indeed wonderful. Price, $\mathbf{\$ 1 . 5 0}$

Winter Queen VII. Color, a beautiful shade of medium pink with a lavender sheen. Here is one of the best pinks for cutting. It has long stems which carry the flowers in good position. The color and formation of this flower are certainly beautiful. Price, $\$ \mathbf{3 . 0 0}$

White Rock, No. 1429. Pure white. Petals long and quite slim like South Pole, curled and twisted somewhat. Small petals, around center. Very good size. Stems good length. Price, $\mathbf{\$ 1 . 5 0}$ 


\section{ADDITIONAL NEW PAEONY-FLOWERED DAHLIAS-Continued}

W. T. MacFarlane, No. 1456. Bright cardinal, heavily clouded yellow at base of petals. Extra long, stiff stems, and good size. A splendid Dahlia for show and bouquet effects. Very desirable. Price, $\$ \mathbf{1 . 0 0}$

Wyoming, No. 602. Light pink heavily clouded yellow on lower half of petals. Small curly petals around center give the flower a fine appearance.

Price, $\$ 1.00$

Yellow Mountain, No. 2099. This mammoth Dahlia is a beautiful shade of canary yellow. Petals slim and stand like.a cactus. An unusually beautiful large center, or disc, surrounded by an immense quantity of short florets formed in curls. An unusually attractive and huge flower. $\quad$ Price, $\$ 5.00$
Yellow Perfection, No. 2424. Paeony. Color clear bright canary yellow. Petals, broad, fold forward, and are quite twisting.

Price, $\$ 5.00$

Yellowstone, No. 2224. Color, pure canary yellow. Here is a flower that should be in every Dahlia lover's collection. The form, color and size are perfectly lovely. This Dahlia should be seen to form an idea of its beauty.

Price, $\$ 5.00$

Yorkshire Hero, No. 845. Color, golden orange with reverse side of petals shaded pink. This is a large flower of good form with numerous curly petals in center, giving it a very attraçtive appearance.

Price, $\$ 2.00$

\section{NEW CACTUS PEONY DAHLIAS}

\section{ORIGINATED BY GEO. L. STILLMAN}

Allie Haley, 2193. The color of this Dahlia is very bright carmine. The florets are quite slim and stand up in a nice fluffy manner. The blossoms are very large and are produced in profusion.

Price, $\$ 2.00$

Cheerful, No. 824. Color, bright light scarlet. A very showy flower on good stem, for cutting. A very free bloomer.

Price, $\$ 1.00$

Cherry Tree, No. 2057. The color of this Dahlia is a beautiful deep cherry pink. It is a very odd shade and of nice formation with good stems.

Price, $\$ 2.00$

Fiery Queen. Color fiery carmine red. A medium sized flower on good stems. Its rich coloring and beautiful form make it a very desirable Dahlia for house or table decoration.

Price, $\$ 1.00$

Forest Fire, No. 414. The color of this Dahlia is a bright, light fiery carmine. The flower is a very good formation. Price, $\$ \mathbf{1 . 0 0}$

Harold Darling, No. 739. The color of this Dahlia is one of those very unusual shades of light orange. The formation of the flower is on the order of a Cactus Paeony, the petals being quite slim and rolled. The color is very unusual and desirable and together with the formation of the flower it makes one of the most beautiful Dahlias of the Cactus Paeony class.

Price, $\$ 2.00$

Laura G. Crowell, No. 2275. Color, very bright carmine with each petal tipped yellow. A very showy, attractive plant, and always covered with a mass of blooms.

Price, $\$ 2.00$

Lusitania, No. 291. Color, rose pink. The numerous long, slim petals are rolled enough to give them a very slim appearance, and stand out, forming large, attractive flowers.
Mammoth Spider, No. 2062. A very large flower. Petals stand out straight without incurving and rolled quite small the entire length. The color is a fine straw color, and a very unusual flower, and immense in size, being 8 and 10 inches across.

Price, $\$ 1.50$

Minnie Best, No. 2004. Color, light salmon pink. florets are quite numerous and narrow and stand quite upright.

Price, $\$ 2.50$

Morning Mist, No. 2059. This is one of the largest Cactus Paeony Dahlias and a wonderful shade of light pink. It is a profuse bloomer and a valuable Dahlia for home and table decorations. Price, $\$ \mathbf{1 . 5 0}$

Mrs. Stillman, No. 218. Color, a beautiful shade of pink. One of the most exquisite shades of pink in the Dahlia family. The flower is of large size and is made up of very long, slim, incurving petals that stand up in a most attractive manner. The color of this Dahlia is pleasing to everyone.

Price, $\$ 2.00$

Nature's Crown, No. 2055. A beautiful shade of salmon pink. A good size for cutting. One of those very desirable shades of pink.

Price, $\$ 2.50$

Pink Crown, No. 2006. A beautiful flesh pink of a most desirable shade. The flower is of the Cactus Paeony type and very handsome. The most desirable shade of pink to be found in Dahlias. Price, $\mathbf{\$ 2 . 0 0}$

Pink Ribbon, No. 2026. The color is a nice salmon pink with a heavy shading of canary yellow at base of petals which are slightly veined in center with yellow. A beautiful flower.
Price, $\$ 2.50$ 


\section{NEW CACTUS PAEONY DAHLIAS-Continued}

The Gay Boy, No. 682. Light scarlet. Petals twisted and pointed and stand up like a Cactus and tipped yellow. Base of petals heavily shaded yellow. A very gay flower on long, upright stems. Price, $\$ 2.00$

Wild Bill, No. 479. Color, bright fiery red. Petals very pointed. A medium size flower, very showy and attractive.

Price, $\$ 1.00$
Wayahead, No. 2180. The color of this large Cactus Dahlia is a deep, rich carmine red. Petals are of unique formation and the flower has good stems. $\quad$ Price, $\$ 3.00$

Velvet Spider, No. 2012. Rich, deep velvety carmine is the color of this new Cactus Paeony Dahlia. A nice heavy flower on a tall plant. Very noticeable.

\section{NEW DUPLEX OR SEMI-P居ONY-FLOWERED DAHLIAS}

\section{ORIGINATED BY GEO. L. STILLMAN}

This is an entirely new, and much needed, classification for a general favorite type of Dahlia. See Dahlia classification on another page.

These Dahlias are not an extremely large flower, but just the right size for cut flower decoration, and they possess the most beautiful combination of colors imaginable.

The following are all new varieties of my own origin:

Adelaida, No. 10. Bright cerise red. Petals tipped with yellow and yellow around bzse with two narrow stripes of yellow through center.

Price, $50 \mathrm{c}$.

Altadena, No. 145. Cerise and white, clouded and mixed together. After the colorings of Mosel. A fine specimen for cutting.

Price, 50c.

Banner Girl, No. 1481. Color, pure white, clouded yellow at base of petal. Petals rolled back whole length. A nice flower.

Price, $\$ 1.00$

Ben Hur, No. 310. Scarlet with yellow circle around disc. Petals slightly tipped yellow. Two veins of yellow run lengthwise to petals.

Price, $\$ 1.00$

Black Servant, No. 2140. Color, rich magenta, almost black. Petals veined and clouded lighter at tips. A very odd colored Dahlia, yet very desirable.

Price, $\$ \mathbf{2 . 0 0}$

Black Valentine, No. 950. In color this Dahlia is rich, dark velvety red. The blossoms of this Dahlia are borne on stiff stems which hold the Dahlia very erect. Fine for cutting.

Price, $\$ \mathbf{1 . 5 0}$

Buster Brown, No. 70. Beautiful shade of canary yellow. This is an immense large flower of unusual qualities. The flowers measure 7 to 8 inches in diameter and have heavy, broad petals, slightly streaked with carmine and borne on extra long stems that are very stout. It is simply a wonderful flower.

Price, 50c.

Camille, No. 474. Color, a purple pink. Base of petals shaded yellow and white. Long stiff stems. Nice for cut flowers. Price, 50c.

Cygnet, No. 818. Color, very deep purple of good size. The color of this flower is much to be desired. It is borne on good stems, making it a fine cut flower Dahlia with a rather unusual color.
Earle Williams, No. 1339. Ruby, striped and shading to white and pink. Large flower and inner petals very curly, outer petals broad and pointed. Fine stem. Price, $\mathbf{\$ 2 . 0 0}$

Golden Crown, No. 247. Color, a rich deep shade of cream. This is a very showy flower. The petals are broad and some are twisted at center. Being shaded red on reverse side gives the flower a pleasing appearance. $\quad$ Price, $\$ 1.00$

Hazel Dawn, No. 1376. Light cerise carmine, heavily veined and clouded yellow. Showy flower with fairly good stems.

Price, 50c.

Hubby Hapgood, No. 510. Color, cerise magenta, shaded white at base of petals. A fine Dahlia for cut flowers. Price, 50c.

James Gray. Color, magenta. A large fluffy flower on long stems. A very showy Dahlia.

Price, $50 \mathrm{c}$.

Jennifer Hadden, No. 333. Color, cerise and white yellow around base. Medium size on good length of stem. Price, 50c.

Koros, No. 659. Color, a very bright shade of maroon. Petals curving around center.

Price, $\$ 1.00$

Latona, No. 420. Color, light coral red, shaded lighter at base. A very striking color. Tall, showy plant. Price, $\$ \mathbf{1 . 0 0}$

Lenore, No. 329. White clouded cerise, but very slightly, nearly white. Very beautiful flower, medium size, with long stems.

Price, 50c.

Lord Baltimore, No. 168. Color, red. Yellow at base and heavily veined yellow in center of petals. Price, 50c.

Maria White, No. 19. Color, magenta, heavily blended white tips. The petals are occasionally heavily veined white.

Price, 35c. 


\section{NEW IOPLEX OR SEMI-FLOWERED DAHLIA-Continued}

Merigold, No. 2005. A light fawn as near as can be described. A clean, nice color and rather unusual. A medium size flower on good stems for cutting.

Price, $\$ 1.00$

Mona, No. 393. The color of this Dahlia is rather unique, being as near as can be i udged, a light crushed strawberry. Medium sized flower and a very desirable shade. Very free bloomer.

Price, 25c.

My Girl Sally, No. 472. Color, deep cherry red, shaded to yellow at base. Petals broad and flat. Fine for cut flowers.

Price, $\$ 1.00$

Not So Bad, No. 2029. Pure white, while each petal is slightly bordered with bright rich carmine. One of the most showy and attractive duplex Dahlias known.

Princess Alice, No. 703. The color of this Dahlia is a beautiful peach pink heavily shaded to light canary at center. Petals are long and broad and roll back to a point at tips. The color is very unusual and the flower is very desirable.

Price, $\$ 1.00$

Reward, No. 2171. Duplex. Color, bright butter yellow, slightly veined pink. Reverse side of petals red. A very large flower and of a fine color.

Price, $\$ 2.00$

Rosy Gem, No. 840. Color, reddish salmon of various shadings, all of which are very desirable and attractive. Price, $\$ \mathbf{2 . 0 0}$

Saffron, No. 876. A g o⿰d sized flower of beautiful shade of peach pink. Price, $\$ 1.00$

Searchlight, No.96. Bright, fiery scarlet. Center surrounded by heavy canary yellow disc. The broad, flat petals are pointed and tipped yellow. 'The New York Horti- cultural Society awarded me a first-class certificate on this Dahlia. Price, 50c.

Song Bird, No. 304. White with faint lines of yellow, and shaded yellow at center. A fine Dahlia for decoration. Price, 25c.

Speedway, No. 251. Rich, deep scarlet. Yellow at base of petals. Petals slightly veined lighter. Flowers very large and bright. Extra long stems. Price, 50c.

Stella Razets, No. 1459. Deep cerise, veined white. Base of petals white, forming a large circle. Petals broad and pointed, somewhat resembling Mme. J. Coissard. Medium size on good length of stem.

Price, 35c.

Sunshine. Color, a lovely shade of deep canary yellow. Petals broad and flat. A fine Dahlia for cut flowers. Price, $\mathbf{\$ 1 . 5 0}$

Underhill, No. 1454. Color, deep canary yellow. Petals slightly shaded and clouded pink at outer edge. Center clear yellow. Petals wide and flat

Price, $\mathbf{5 0 c}$.

Van Dyke. Paeony. Reddish salmon pink. The petals curl and twist with lot of small curly ones around the center. A beautiful color and large flower. Price, $\$ 2.00$

Variation, No. 1445. Lemon yellow. Petals finely veined and clouded throughout with cerise. Some flowers lighter than others. Base of petals yellow. A very showy flower with good stems. Price, 50c.

Yawcob Strauss, No. 253. Light red, yellow at base. Heavily clouded and veined yellow. Petals stand up and edges roll back slightly. Long stems. Medium sized flowers.

\section{NEW SHOW DAHLIAS \\ ORIGINATED BY GEO. L. STILLMAN}

Aviator, No. 2123. Pure white heavily clouded pink. A very large beautiful flower of the Show Dahlia family. A very free bloomer. Blossoms are carried on good stems for cutting.

Price, $\$ 2.00$

Budd Fisher, No. 384. Hybrid Show. Color, a deep striking carmine. A very rich desirable color. Petals are quite pointed at the very tips.

Price, $\$ 1.00$

Ch. Dyker Dolly, II, No. 1486. Iight brick red. A large flower and a fine bloomer.

Price, $\$ 1.50$

Democrites, No. 1106. Cardinal. Good sized flower, full center.

Price, $\$ 1.00$

Earliana, No. 2105. A beautiful shade of clear canary yellow. A large Show type of perfect form on good stems. Price, $\$ 1.00$

Frank Mallon, No. 202. Color, deep butter yellow slightly veined light red. One of the freest blooming Dahlias and good size.
Gen. Booth, No. 1368. Beautiful shade of light purple. Flowers very large and have long stems, standing high above the foliage. Price, 50c.

General Custer, No. 1441. Reddish salmon clouded slightly yellow at base of petals. A very large flower on good length of stem.

Price, $\$ 1.00$

Golden Cluster, No. 2205. Hybrid Show. Color, light butter yellow with each petal slightly tipped and clouded pink. The reverse side of petals pink. A large flower on good stems and a profuse bloomer.

Price, $\$ 2.00$

Golden Shore No. 1438. Canary yellow; tips of petals shaded pink. A most strikingly clean, perfectly formed flower and very large. A perfectly cupped flower and full center.

Price, $\$ 2.00$

John Stanhope, No. 312. Very red salmon. Large flower on long stems. Most desirable rich color.

Price, $\$ 1.00$ 


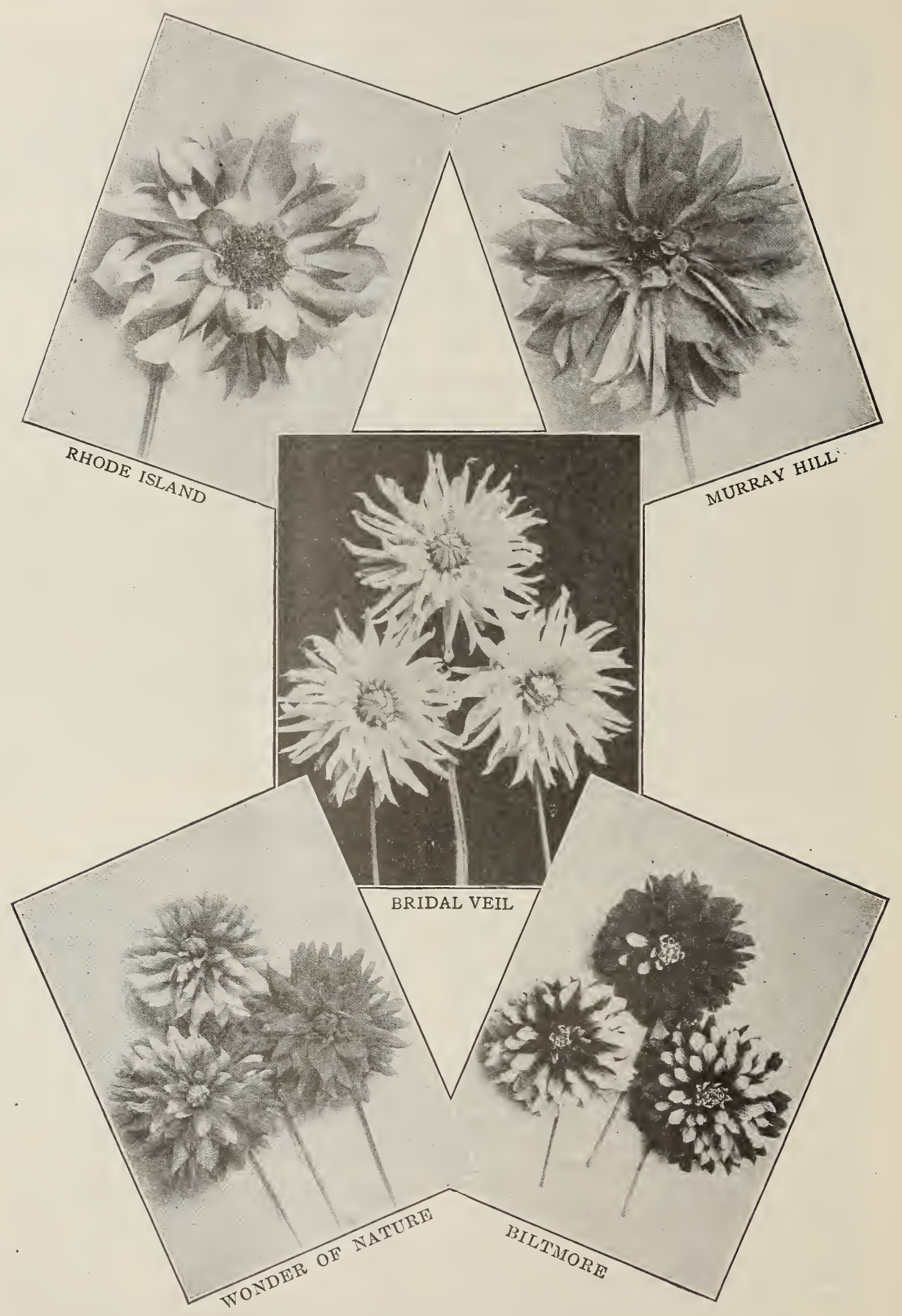




\section{NEW SHOW DAHLIAS-Continued}

King of Shows, No. 1439. Deep butter yellow of a solid color throughout. Every petal is most perfectly quilled and uniquely formed. A mammoth flower, on long stems. It is without doubt the finest Show Dahlia ever grown and should be seen to be appreciated.

Price, $\$ 2.00$

Largest of All, No. 1421. Beautiful shade of dark lilac. A mammoth Show Dahlia in every sense of the word. A beautiful color and form. Stems good length. Should be seen to be appreciated.

Price, $\$ \mathbf{5 . 0 0}$

Mariam Cooper, No. 381. Light canary yellow, slightly overcast with pink. Reverse side of petals heavily clouded pink. A large size flower and a good form. Price, 75c.

Ox Blood, No. 210. A very clear red. Very large Show Dahlia on extra long stems, like "Le Colosse," and a trifle darker shade.

Price, $\$ 1.00$

Red Ball. Show. Medium light red. A very large show on long heavy stems. This flower is even larger than its parent "King of Shows". Large, full, and perfect quills. Price, $\$ 3.50$

Red King, No. 1487. Hybrid Show. Rich, deep carmine. Flowers extra large and extremely bright color. One of the giant Shows.

Price, $\$ 1.00$

Scarlet Giant, No. 1489. Deep fiery scarlet. A most wonderful flower both in color and size. A very free bloomer with good stems. The brightest and most attractively colored Show Dahlia. Price, $\$ \mathbf{1 . 0 0}$

Silva Quarta, No. 2264. Color, pure lavender. This is an entirely new species of Show Dahlia of a most unique form. The quills are very perfect and each one contains an inner quill like the outer one making a double quill which shows very pronounced. A new novelty; a double quilled Show Dahlia. It is perfectly ball-shaped and a very desirable color. The finest Show Dahlia I have ever produced.

Price, $\$ 15.00$

Sir Roger, No. 2184. Color, light pale red. A large Show Dahlia. The flowers are coarse and well quilled, and are borne on long, stout stems.

Price, $\$ 2.00$

Tennis Ball, No. 2265. Color, a purple magenta. This flower is finely cupped and is borne on long, stiff stems. One of the best Show Dahlias.

Price, $\$ \mathbf{2 . 0 0}$

The Hermit, No. 1437. Deep brick red. Petals small, numerous, and slightly cupped with good stems for cutting. Good flower and very desirable and attractive. Stems good length.

Price, 75c.

Yarrow, No. 2232. Color, canary yellow. This new Show Dahlia is the real thing which has been looked for so long in the Show Dahlia class. It is a clear, bright canary yellow and a large flower about the same size of the King of Shows. It is a perfectly quilled bail-shaped flower and is held upright on good stems.

Price, $\$ 3.00$

\section{NEW COLLARETTE DAHLIAS}

\section{ORIGINATED BY GEO. L. STILLMAN}

Annette, No. 271. Color, yellow at base of petals, balance of petals cerise, shading to white at tips. The collar is nearly white, with cerise shadings.

Price, 25c.

Capt. Roycroft, No. 1372. Dark maroon. Collar white, bordered with pink. A large, fine color in Collarette style. Long stems.

Price, 35c.

Caroline, No. 1483. Deep velvety maroon. Petals broad and flat, collar maroon with clouds of white at tips. Price, 50c.

Color Blender, No. 128. Base of petals yellow for a quarter of an inch. Outer rim of petals from base to tips yellowish cream. The entire center of the petals is a bright crimson. In some of the flowers the crimson covers the entire petals, only the rim is a shade lighter. The most beautiful Collarette known. Free flowering. Price, 75c.

Daisy Smith, No. 132. Canary yellow' slightly clouded pink. Collarette lighter canary.
Grace Loretta, No. 272. A very rich purple magenta with a nearly white collar. The very richest color of any of the Collarettes and the flower is of good size.

Price, 50c.

Heatherbelle, No. 130. Yellow, center is surrounded by Collarette of yellow, faintly tipped white.

Price, 35c.

Jumbo, No. 126. Deep scarlet with shadings of yellow overspreading the flower. The collar petals are quite long and red and yellow in color. The largest Collarette.

Price, 25c.

Mons, Poirier, No. 274. White and yellow at base of petals. Center light cerise. Tips of petals white. Fine veins of white running lengthwise of petals. Price, 50c.

Peggy O'Neil, No. 1413. Deep ruby, shading lighter at tips of petals. Collar white with fine veins of ruby red. One of the finest.

Price, 35c.

The Peach, No. 1123. Amber and red veined and striped. White collar. Price, 50c. 


\section{NEW COLLARETTE DAHLIAS-Continued}

Wilda, No. 1397. Clear light purple or jacond. Base of petals yellow; a very striking contrast of colors. Price, 50c.

Winfield, No. 1361. Deep, velvety magenta with white collar shaded with magenta. A fine Collarette. Good size, on long stems.

Price, 50c.
Yellow Prize, No. 133. Light canary yellow. Some of the flowers have blotches of red at base of petals. The collar is yellow and white blended together. This Dahlia has a most beautiful foliage for decoration and is a free bloomer. Price, 50c.

\section{NEW SINGLE DAHLIAS}

\section{ORIGINATED BY GEO. L. STILLMAN}

Alemeda, No. 44. Deep crimson magenta. Veined and shaded white. Lighter at base and tips of petals. Medium size flowers and fine for cutting. Price, 25c.

Anita King, No. 1341. Cardinal with two and three stripes of orange running through petals. Base of petals shaded yellow. A fine color.

Price, 35c.

Aukum, No. 1073. Light pink. A very good cut flower Dahlia of medium size and with free-blooming qualities. Price, 25c.

Blushing Boy, No. 1096. Very dark maroon. Center of petals and tips pure white. Occasionally some of the petals come solid dark maroon. A striking combination.

Price, $\$ 1.00$

Chanticleer, No. 1366. Color, cinnamon, faintly streaked with gold. A very striking color.

Price, 25c.

Color Card, No. 11i6. A Dahlia of many colors and shades, having yellow, red, pink and amber in very attractive shades.

Price, 35c.

Erebus, No. 645. Pink and white clouded together. A good, large flower and beautiful color.

Price, $\$ 1.00$

Fang de Charmer, No. 1097. Clouded pink. This is the most peculiarly marked Dahlia that has ever come under my observation. The tip of each petal is serrated in a diamond shape. At the base of the diamond are two fangs with sharp points, hence, the name "Charmer." One of the most profuse flowering single Dahlias in my collection.

Price, 35c.

Greyhound, No. 1027. Color, a combiilation of salmon, copper and brown. A very unusual, odd color. Large flower with broad, flat petals. A faint collarette, of a lighter shade, surrounds the center. Price, 50c.

Happy Days, No. 2453. Color, magenta with each petal heavily tipped white. One of the most beautiful and attractive single Dahlias I have ever seen. Fine for cut flowers.

Price, $\$ 1.50$

Laura H. Crews, No. 1012. A pretty light pink single with finely formed flat petals of good size.

Price, 25c.

Lorraine, No. 679. Color, dark red with a slight tinge of purple. Deep bright carmine and good for cutting. Price, 50c.
Lulu Linton, No. 1358. Very pale yellow. Heavily shaded and streaked purplish red. A very showy large single Dahlia.

Price, 50c.

Margaret Ward, No. 1059. Deep lavender pink. Petals broad at base and sharp at point. Good size. Small white center.

Price, 25c.

Mountain Pink, No. 952. Color, very beautiful shade of light pinkish lavender tinted with yellow around the florets. One of the very best singles yet produced.

Price, $\$ 1.00$

Ox Eye, No. 1086. Carmine with yellow base. Has the appearance of the ox eye.

Price, 20c.

Peggy Lundeen, No. 138. Color, slightly yellow, base of petals encircled with white. Then the petals are cerise tipped and clouded' white. Beautiful colorings. Price, 25c.

Peppermint, No. 2125. The color of this beautiful Single Dahlia is pure white. Each petal is heavily bordered with deep rich magenta. This is without doubt the most striking and beautiful Single Dahlia yet produced. The blooms are a good size, being borne on good long stems for cutting. The flowers stand well above the foliage and it is an unusually free bloomer. Price, $\$ \mathbf{1 . 0 0}$

Phidias, No. 652. Rich magenta with a light cream ring around disc. Tips of petals lighter. A fine single.

Price, 50c.

Polly, No. 121. White, flushed with pink. Tips of petals serrated. A good single.

Price, 15c.

Prince of Yellows, No. 142-2. Color, a beautiful rich canary yellow. Petals broad and flat.

Price, 20c.

Prosperton, No. 810. Color, medium shade of carmine. Each petal is serrated at tips and heavily clouded yellow at tips; clouded and veined through the middle and nearly all yellow on lower half. A very showy, large flower for a single Dahlia.

Price, $\$ 1.00$

Radiance, No. 1014. Deep, rich magenta, slightly tipped white. A beautiful thing for table decoration. 


\section{NEW SINGLE DAHLIAS - Continued}

Single Jane, No. 21. Deep, velvety magenta with a shading of white and yellow at base of petals and a blending of white at tips. A fine combination. Extra long stems.

Price, 35c.

Snowflake, No. 2052. This Dahlia is pure glistening white with broad, flat petals forming a flat flower which stands erect on long stiff stems. The most beautiful white single Dahlia yet produced. The beautiful large yellow disc in this flower gives it a beautiful finish.

Price, $\$ \mathbf{1 . 0 0}$
Star of the East, No. 1103. Magenta, yellow at base, edges and tips clouded white, Price, 15c.

Susie, No. 1081. Single Dahlia of a pleasing shade of rather dark velvety magenta with one or two faint streaks of light shade running through petals.

Price, 15c.

Tama, No. 1362. Magenta: This flower should have a place in every garden.

Price, 50c.

\section{NEW POMPON VARIETIES ORIGINATED BY GEO. L. STILLMAN}

Belle of Georgia, No. 1467. Deep, rich carmine. Occasionally speckled with white. The entire flower is composed of globular petals, resembling perfect quills with the closed end cut off. A peculiarity seen in no other Dahlia. A very free flowering pompon

\section{CACTUS DAHLIAS}

Advance. Light red, this Dahlia is one of the largest of the Cactus varieties. The flowers are very full to the center and the best of form.

Price, 25c.

Alexander. Dark crimson, flushed maroon. Extra fine form and good, free bloomer. Good habits of growth and very productive.

Price, 50c.

Ami Bethier. Light carmine red, almost crange red. Very large, with long petals. P jints sharply and finely twisted. Very fine and desirable flower.

Price, 25c.

Attraction. (Foreign.) Color, a very beautiful pink with a lavender sheen. The f orm and size of this Dahlia are equally good. The blossom is borne on nice long stems for cutting.

Price, $\$ \mathbf{2 . 0 0}$

Cardinal. A very good Dahlia of a cardinal red shade.

Price, 25c.

Chastity. A very pretty pale pink of very finely twisted Cactus petals which stand up most attractively. As held up the center has the appearance of being white. Its stiff stems hold it erect. Should be seen to be appreciated. Fine size. Price, 50c.

Citizen. Dark maroon, large flower, shaded purple. Grows very strong and erect, and is free flowering.

Price, 20c.

Clara G. Stredwick. Clear, bright salmon, shading yellow at base of petals. Large flowers, with long, slim, twisted petals. Very ttractive and free.

Price, 25c.

Columbia. Vermilion, tipped and striped with white. Long, narrow petals. The plants make very little foliage and the flowers are carried well above it. It blossoms profusely, and with its variety of coloring it presents a most striking appearance.

Price, 25c.
Comte Da Ribeira. Yellow, tip sulphur color. Shading yellow and lilac at center. Color unique.

Price, 35c.

Conservateur Lefebvre. Salmon pink, Flowers very large and a free bloomer. The base of the petals is light buff, which shades toward the points to salmon and pink, giving the flower a delicate glowing pinkish appearance.

Price, 25c.

Countess of Malmsbury. Inner row of petals white, outer rows pale pink, shading toward white. A dainty and pleasing var iety.

Price, 25c.

Country Girl. Inner row of petals broader than outer; of a pleasing shade of yellow. Outer petals nicely rolled, base being yellow, tips orange.

Price, 25c.

Cycle. Red, slightly of a pinkish shade, tips of petals tinged with a shading of white. With plenty of fertilizer this Dahlia will produce magnificent flowers. Although it sells for a very low price, it is an exceptionally desirable Dahlia.

Price, 15c.

Dainty. The name Dainty aptly describes this charming novelty. The ground color is lemon yellow, which becomes paler with age and is more intense, almost approaching canary yellow, at base of petals.

Price, 25c.

Daisy Staples. Color, bright mauve pink, center good, stems long and wirelike, free flowering and reliable.

Price, 25c.

Delicatissima. A beautifully formed Dahlia. Color, white veined and lightly suffused pale lilac rose. 


\section{CACTUS DAHLIAS-Continued}

Dorothy Vernon. Crushed strawberry. This is entirely different from any other Dahlia having all shades of crushed strawberry. The flowers are of a beautiful form and very attractive.

Price, 25c.

Delight. Pale pink, center shaded yellow.

Price, 25c.

Dr. Mene. Amber and yellow. Flowers are large and deep. In color, a rich amber, while the center is mottled amber and yellow. A most desirable Dahlia.

Price, 25c.

Else. Salmon pink, slightly suffused yellow. Blooms very freely. A most beautiful shade.

Price, 25c.

Emperor. Plum color, pale yellow at base of petals. A very desirable Dahlia.

Price, 25c.

Ericka Bornemann. Light rosy pink, growing lighter toward the center. Small size flower. Very abundant bloomer, and extremely dainty color. Fine for boutonnières.

Price, 25c.

Etendard de Lyon. Broad, wavy petals, color between a rich carmine rose and royal purple. One of the best.

Price, 75c.

Etruria. Color, golden orange. This blossom shades yellow and orange. Petals are long, slim and tightly rolled, very much incurved. Base is yellow shading into orange, and tips are yellow. A charming and beautiful variety.

Price, 25c.

Fairy. A dainty medium size flower of pure white; an exceptionally free bloomer.

Fantassima. Petals are long and narrow, curling upward, of true Cactus type. Inner rows of petals are salmon pink. Outer rows of petals are pinkish lavender shade. Backs of petals are much deeper in tone of a pinkish violet color.

Price, 50c.

Faunus. One of the best. Color soft yellowish buff, tipped salmon. Large flowers.

F. I. Pateman. Lovely bright yellow. Of good size and unusually attractive.

Price, 35c.

Flame. Orange scarlet. Florets are long and twisted. Flowers are carried on good stems. Very bright and attractive. One of the newest and best.

Price, 25c.

Flieder. Lavender and white. A very large flower of unusual beauty, both in color and shape.

Price, 25c.

Foxhunter. Bright scarlet. Very large, with incurved petals. A beautiful flower and free bloomer.

Price, 25c.

Freibigkeit. Deep pink. Flowers medium size, well formed, with sharply-pointed petals of a deep crimson pink color.

Price, 35c.

Gen. Buller. Rich, velvety crimson, variegated. This beautiful Dahlia should be seen to be appreciated. The rich crimson flowers, with their white tips, together with some that are nearly all white, and some all red, present a most striking appearance.

Price, 25c.
Goodhope. Deep red striped with white. Price, 50c.

Golden Gate. A good flower of a deep golden yellow, tinted bronze or russet; very free; flowers immense size. Price, 50c.

Golden Wave. This is a rich, deep, pure yellow. A very desirable Dahlia. Price, 35c.

G. W. Childs. Deep garnet, with rich velvety appearance. Very large and full, with long, twisted petals. One of the best Garnet Dahlias, and blooms profusely.

Price, 25c.

Hyacinth. Yellow and pink. Combination of colors of unusual attractiveness. Good size and blossoms freely. Price, 25c.

Imperial. A large Cactus; color, yellow, disc quickly changing to reddish carmine. A vigorous grower. $\quad$ Price, 25c.

Ingleboro Edgealand. Medium size. Center of yellow, balance of flower of a good, clear, medium velvety red. Price, 35c.

J. B. Riding. Yellow base, shading to deep orange. Large flower of fine form. Very attractive.

Price, 25c.

J. H. Jackson. This is one of the best black Cactus Dahlias. Its velvety black maroon shade is very striking. The flower; are very large with long stems and stand out well from the foliage. Every lover of Dahlias should plant a J. H. Jackson.

Price, 25c.

J. Weir Fyfe. Dark maroon, sometimes shading to bright purple. A beautifully formed, free blooming Dahlia. Price, 25c.

Jeanne Cayeux. Light terra cotta. Flowers large, with long, slim, finely-curved petals. Petals lighter toward the base.

Price, 25c.

Juliet. Magnificent rose tinted pink. A very distinct flower.

Kalif. Medium carmine. A very large, solid color flower.

Price, $\$ 1.00$

Kathleen Bryant. Dark maroon. Large flower of a beautiful maroon shade and fine form. Price, 25c.

Kapiolani. Hybrid Cactus. Very large flower, dark crimson in color. Petals broad but twisting to points at tips. Very attractive.

Price, $\$ \mathbf{5 . 0 0}$

Kleber. Dark scarlet. One of the most free blooming reds. Flowers are of large size and a very desirable color. Price, 25c.

Koolankopo. Butter yellow. heavily clouded and striped bright red. A large flower of good formation. Price, $\$ \mathbf{5 . 0 0}$

Kreimhilde. Light pink with white center. Flower has curly petals, and is one of the most attractive Cactus Dahlias. This Dahlia should be in every collection.

Price, 25c.

Loadstone. Light flame color. Very claw-shaped, twisted petals. A strong grower and a free bloomer. 


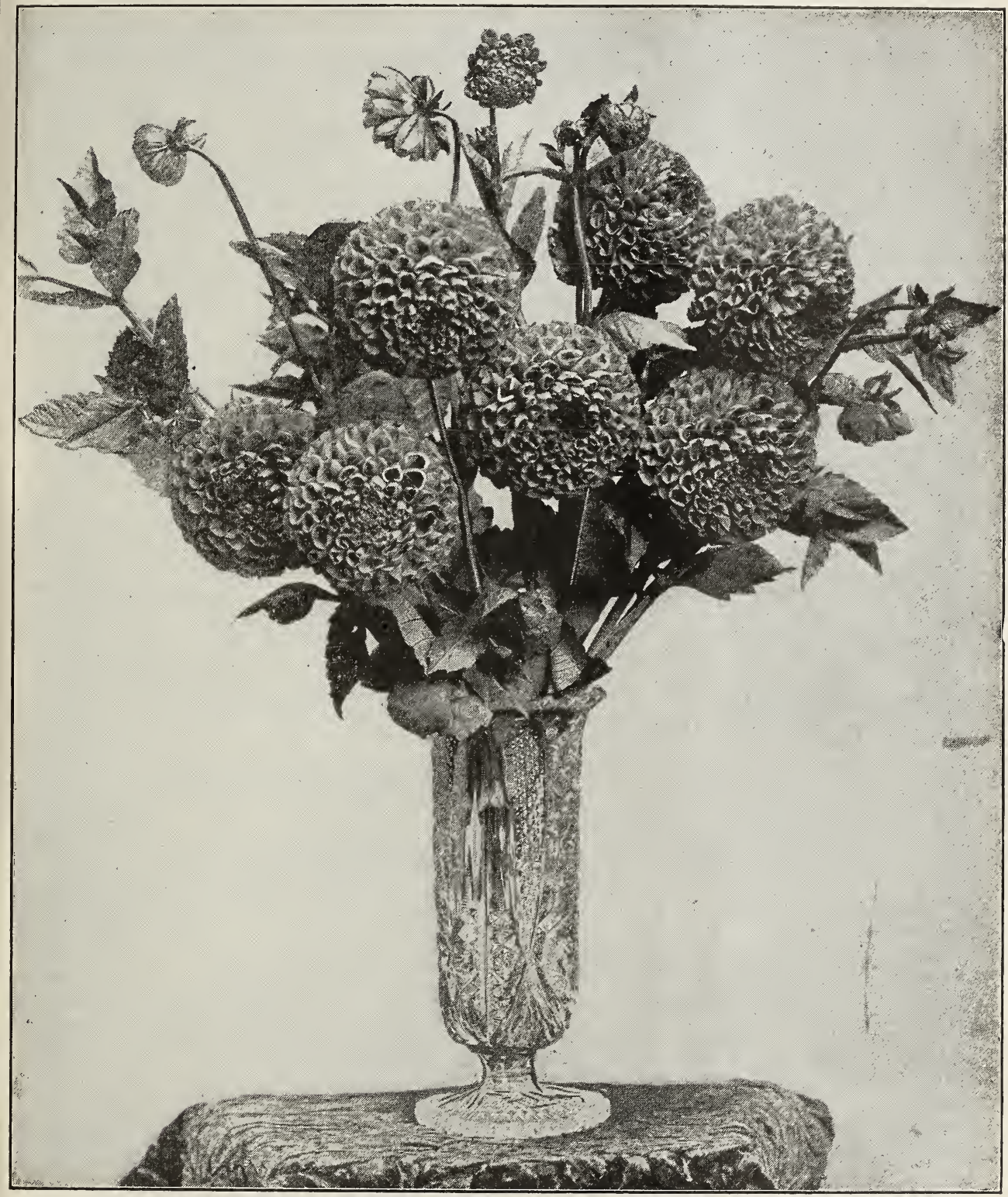

KING OF SHOWS 


\section{CACTUS DAHLIAS-Continued}

Lord Minto. Very light salmon pink. with delicate lemon yellow shading in center. Petals finely twisted and incurved. Points evenly and finely serrated. Flowers freely produced.

Lucio. Yellow and white. Flowers of large size. Base of petals light butter color, tips are pure white, making a beautiful combination of yellow and white.

Price, 25c.

M. Pierrot. Amber with tips white and base of petals yellow. Some of the flowers come without white tips.

Price, $\$ 1.00$

Marion. Old gold in center, passing to a lovely swamp pink; the middle of petals being veined and suffused with old gold, while the reverse of petals is a rich carmine pink, making it a most lovely combination of colors. The blossoms are large and produced very freely.

Price, 25c.

Marroko. Beautiful shade of very dark pink, changing to purple. Medium size, very rich in appearance and most desirable. Price, 25c.

Mephistopheles. Hybr.d Cactus. The flowers are very large and of fine form. The color is a vivid scarlet. $\quad$ Price, $\$ 5.00$

Mme. Henri Martinet. Salmon pink shaded sulphur yellow at base of petals. A profuse bloomer and a beautifully formed flower of good size.

Maravigalla. Color, light rose, with golden tips. florets slightly serrated at tips. Extra fine.

Marjorie Castleton. The outer florets are rose pink. The tips and inner florets are pure white.

Mary Farnsworth. White, slightly shaded light yellow at base. A very incurved variety.

Price, 25c.

Mary Keeling. Color, orange, shading toward yellow. Very pretty. Price, 25c.

Mayfield Beauty. Pink, shaded to yellow. A very unusual shade and one that attracts attention everywhere. A very desirable, medium size, low-priced Da'ilia.

Price, 25c.

Miniature. A rosy carnation carmine. An exquisite mixture of these delicate colorings. Entirely new.

Price, 2sc.

Mirifique. Purplish $\mathrm{m}=$ roon. Flower; large, with long, slim, pointed, straight petals. A fine bloomer and durable flower.

Miss Crice, 50c. Miss Constance Farmer. Dazzling magenta. Very large flower, with long, slim petals, much claw-shaped and twisted. An elegant flower and most desirable in every garden.

Price, 25c.

Miss Fanny Foster. Variegated. Flowers of medium size. Some Hluwers a clear, deep red, others white with stripes of red. A fine Cactus Dahlia.

Price, 25c.

Miss Perry. Salmon with apricot shadings. Tips pinkish rose. Stems long and stiff.
M. Cazalis. Light magenta. Flowers of medium size and fine shape. Petals nicely pointed and curved. Flowers are white and magenta, beautifully blended together. A rare and striking combination of color.
Price, 25c.

M. Pol Varin. Bronze yellow. Unique form and a shade rather unusual and yet desirable. $\quad$ Price, 25c.

M. Rodger Lecler. These flowers are of large size and light sulphur yellow. Tips of petals are a shade lighter. This is an extremely free bloomer, and flowers are borne well above the foliage. A beautiful Dahlia.

Price, 75c.

Mrs. C. H. Breck. Light red, tipped and overspreading more or less with white. A very showy, attractive Dahlia. Petals are broad at base and rolled to sharp points at the tips. A large flower and one of the most attractive Cactus Dahlias. Price, 75c.

Mrs. E. Mauley. Clear yellow. Fine formed, large flowers with long curly petals. One of the best yellow cactus Dahlias. A beautiful shade and very desirable in every way.

Price, 25c.

Mrs. Douglas Fleming. White. Petals serrated. A low plant. Price, $\$ 1.00$ Mrs. F. Grinsted. Rich crimson and purple. Flowers finely curled and of large size. A most beautiful Dahlia. Price, 25c.

Mrs. J. Emerson. A delicate lovely yellow, shading nearly white at tips. Some of the petals marked with very fine lines and dots of red. A large and beautiful specimen.

Price, 25c.

Mrs. J. W. Wilkinson. Fine pink. Petals very incurving and of beautiful form. Price, 25c.

Mrs. Moore. Deep carmine. Very full and fine form. Long stems and blossoms freely. $\quad$ Price, 25c.

Mrs. D. B. Crane. Pure white. Flowers of medium size and free blooming. Price, 25c.

Mrs. De Luca. Golden yellow, tipped with orange. Large bold flowers, with very curly, incurved petals. A very attractive Dahlia. Free bloomer. $\quad$ Price, 25c.

Mrs. Reginald Bailey. This Dahlia should be seen to be appreciated. A beautifully deep violet red. The long, rolled petals curl upward, making it a true Cactus. One of the best and most distinct. Price, 50c.

Mrs. Seale. A charming and pleasing novelty. Inner rows of petals more than half way to tips are blackish red. The red is so very dark it seems almost to be touched with black. Tips of petals white. Outer rows of petals are broader, and about half of the petal is white, while the base is not as dark red as on the inner petals. Price, 35c.

Mrs. Stephen Clarke. Pink shaded. white. Good size and free. Price, 25c. 


\section{CACTUS DAHLIAS-Continued}

Mrs. T. G. Baker. Color a rich deep orange, gradually shading to yellow near the base of the petals. The blooms are very large, petals very long and narrow, and never come shallow. A most reliable variety for exhibition or garden.

Price, 75c.

Mrs. T. W. Willis. A very large and exquisitely colored blossom, with very narrow florets its entire length. White in the center with edgings of lilac on the younger florets, the greater part of the bloom being rose lilac.

Price, $50 \mathrm{c}$.

Nahida de Semelle. Color, light scarlet. Rolling petals, sharply pointed at tips. A very unique flower.

Price, 25c.

Nibelungenhorte. Rich golden apricot suffused old rose. The plant is a giant, being very strong and vigorous, producing massive flowers early and freely on very long stiff stems.

Price, $\$ 1.00$

Octopus. Very light pink, shading to creamy white in center. Large flowers. Very attractive and desirable Dahlia.

Price, 25c.

Pearl De Lyon. Pure white. Very large, full flowers. Florets serrated at points, giving the flowers a fine feathery appearance.

Price, 25c.

Primrose. The name of this Dahlia aptly describes its color, for it is a true primrose. Flowers are very large and perfectly formed.

Price, 25c.

Premier. Scarlet. One of the most refined and desirably shaped Cactus Dahlias.

Price, 25c.

P. W. Tullock. Light salmon red, tinted purple. A very showy, free bloomer. Petals much incurved and resemble the chrysanthemum very closely.

Price, 25c.

Pink Pearl. Rosy pink. Beautiful and delicate shading. Should be seen to be appreciated.

Price, 25c.

Queenie. Base of petals orange colored, shading out to bright scarlet. A perfectly handsome, very large specimen. Petals slim and long, and somewhat curled, making it a charming variety.

Price, 25c.

Reine Wilmot. The center of this flower is yellow, shading out to a bluish pink. Handsome and attractive.

Price, 25c.

Richard Box. Light cream. Large flower with slim and sharp petals. Price, 50c.

Rose Queen. Cactus. Bright firey scarlet. A nice cactus of medium size.

Rupert. Pale amber yellow at base. A fine shape and color.

Price, $\$ 1.00$

Sardigna. Dark purple; very large flower of rich shade. Full to the center and free bloomer.

Price, 35c.

Sir A. Lamb. Crimson, shaded purple. Florets very pointed. A very attractive flower of fine form.
Southern Belle. Deep maroon with center petals almost black. A very claw. shaped Dahlia.

Price, 50c.

Standard Bearer. Rich, light carmine. A standard variety of superior merit. An excellent color and a very free flowering variety. Price, 25c.

Starfish. Clear scarlet. Large finely formed flowers, borne well above the foliage, making a very showy and attractive plant. This is a very desirable Dahlia, although sold at a low price. Try a few of this variety.

Price, 25c.

Spotless Queen. Pure white. A very abundant bloomer of medium size. Fine for cut flowers.

Price, 25c.

Success. Deep canary yellow. Petals small and sharp at ends. Price, 35c.

Sybaris. Pure white, with small twisted interlaid florets. Very fine and desirable.

Price, 25c.

T. A. Havemeyer. Base of inner rows of petals is yellow. The rest of the petal is a brickish red, slightly tinted with purple. Petals are very slim, well rolled and curi upward in a charming manner. Very attractive.

Price, 25c.

Thuringia. Light flame color, with deep orange tints. Long, straight petals. Large blossoms borne on long stems. Price, 50c.

Torpille. Dark reddish pink, striped with white. Very odd. Full, well shaped blossoms. Desirable as a novelty. Price, 25c.

Una. A pretty Cactus Dahlia of a mixture of pink and white. The petals are extremely fine and each one serrated, giving a decidedly feathery appearance. The pink is somewhat spotted through the petals. Very good size and very desirable. Good stems.

Price, $\$ 1.50$

Vater Rhein. Flowers over 6 inches in diameter, raised well above the foliage on stout stems. Petals broad, curled and twisted, the color of which is yellow, suffused with salmon-rose; a beautiful and attractive flower.

Price, 25c.

Venezia. Clear magenta petals, serrated at points, making a very unusual feathery appearance. Very desirable in every way.

Price, 25c.

Victor Von Scheffel. Exquisite, delicate light pink shading to pure white in center; somewhat resembles Kriemhilde in color. Blossoms medium size and borne on long stems.

Price, 25c.

Viscountess Shearbroke. Reddish terra cotta. Large and free. Very showy.

Price, 25c.

Zoo. - Two inner rows of petals rich crimson, while the remainder of the petals around the outside are deep brilliant scarlet.

Price, 35c. 


\section{DECORATIVE DAHLIAS}

\section{I prepay carriage on all retail bulb orders, accompanied by cash in full, in the United States. This does not apply to Special Offers.}

Ardene. Dec. Deep butter yellow. Petals fold back and twist at points. A good size flower on good stems for cutting.

Price, $\$ 5.00$

Atlanta. Almost white, softly shaded with lavender. Blossoms somewhat resemble the Cactus variety. Flowers freelv.

Price, 25c.

Autumn Gold. Light yellow petals bordered and heavily clouded pink. Petals medium, slim, and twisting. Price, 50c.

Bermuda Red. Dark Crimson. A good sized flower. $\quad$ Price, 50c.

California. A beautiful bright rose pink. An extra good Dahlia.

Price, 25c.

Capt. Jack. Decorative. A very pretty Dahlia of yellow and deep amber. The outer petals are yellow, while those in and near the center are deep amber. Price, $\$ \mathbf{1 . 5 0}$

Catherine Cooper. Dec. A beautiful shade of rose pink. A mammoth Dahlia on strong stems which hold the blossom erect.

Price, $\$ \mathbf{2 . 5 0}$

Chieftain. Clear, light red, heavily streaked and splashed canary yellow. Some of the flowers come clear red. Very large and attractive flower.

Price, $\$ 1.00$

Creamo. Color, deep straw. This Dahlia is shaped like a Decorative, but each petal is a perfect quill like those of a Show Dahlia except the outer row which is more open. This is a very extraordinary specimen and the flower is borne on long, stiff stems.

Price, $\$ 1.00$

Crimson Giant. Deep crimson flowers, and produced very freely on tall plants.

Price, 25c.

D. M. Moore. Rich velvety maroon. Flowers of mammoth size. Extra good.

Price, $\$ 1.00$

Dr. Tevis. The color of this monster Dahlia is a combination of pink, old rose, copper, and old gold. A beautiful flower on fine stems.

Price, $\$ 3.00$

F. Lawton. Pale, delicate shade of light yellow. Flowers borne on good stems. Petals curled somewhat around center like Paeony-flowered Dahlias. Very pleasing specimen.

Price, 25c.

Gates Red. Dark, velvety carmine, good size, slightly darker toward center.

Price, 35c.

George Walters. Color a rich deep flesh pink, or perhaps a shading of lavender overcasts it. A very large flower and of fine form.

Price, $\$ \mathbf{2 . 0 0}$

Glory of Wilts. Extra large, beautiful blossoms. Color, clear bright yellow.

Price, 25c.
Gold Finch. Main petals are light salmon while center petals are canary yellow. A very deep Dahlia on very heavy stems.

Price, $\$ 5.00$

Insulinde. The color is a rich golden orange, suffused with bronze and apricot shadings. The broad petals wave and curl in the most artistic manner. Price, $\$ \mathbf{1 . 5 0}$

Jacques Welkin. Color deep pink, with the outer edge of petals a trifle deeper than the center. A very pretty Dahlia with a very few blotches of white on the pink petals.

Price, 25c.

Judge Marean. This Dahlia is ever changing as the flower ages, salmon, pink, red, orange, yellow and pure gold. Price, $\mathbf{\$ 5 . 0 0}$

King of the Autumn. A well-known decorative Dahlia. Color buff, yellow and terra cotta shade. $\quad$ Price, $\mathbf{\$ 1 . 0 0}$

Kalaeokahio. Color, salmon pink, deeply shaded golden yellow in center. Good size flower and an odd color. Price, $\$ \mathbf{2 . 0 0}$

Le Grand Manitou. Ground color, pale pink, striped, spotted and blotched with deep reddish violet. Flowers frequently come solid colors. Borne on stout, stiff stems, held well above the foliage.

Price, 50c.

Lord Kitchiner. Dec. Bright canary yellow. A flower with a full center and on long stiff stems which hold the flower erect. A dandy Dahlia for cutting. Price, $\$ \mathbf{2 . 5 0}$

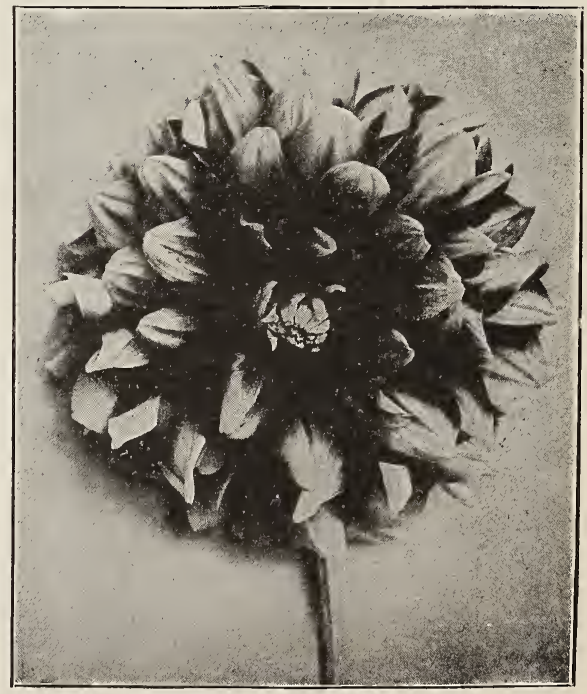

PERFECT BEAUTY

The New Decorative Dahlia 


\section{DECORATIVE DAHLIAS-Continued}

M. Burel. Dark apricot yellow in center, shading lighter toward edge of petals, which are faintly lined and dotted with dark apricot. Large blossoms borne on good straight stems. A handsome variety.

Price, 25c.

Mina Burgle. Deep scarlet, solid color. A large flower of fine form and a beautiful rich, bright color. A fine flower. Price, 50c.

Minos. Rich, velvety maroon. Flowers are large and very beautiful and are borne on long stiff stems. The petals look like satin and to look into the heart of the flower it appears to be a velvety black. A thoroughly handsome Dahlia.

Price, 25c.

Mme. Burel. A delicate shade of light pink, striped and spotted blood red. Petals slightly curled. Large blossoms borne on long, stiff stems. Very desirable.

Price, 25c.

Mme. L. Tillier. Deep salmon, shaded down to light yellow at tips. A beautiful combination of colors.

Price, 25c.

Mme. Louis Harriot. Large, beautiful yellow. One of those clear, light yellows that are so attractive in a Dahlia. Much the same shade as "Mrs. Chas. Turner." Try one and see if you are not satisfied that it is both large and beautiful. Price, 25c.

Mme. A. Nonin. Base of petals white, tips light lavender. Very pretty. Price, 25c.

Mme. Victor Vassaire. Clear, beautiful yellow. If you wish to secure a handsome Dahlia now is the time. This is a large and perfectly formed decorative Dahlia. A yellow beauty.

Price, 35c.

Manitou. An immense amber bronzecolored blossom. Has a distinct shading of pink; is extra large and full, and unusually desirable. An excellent Dahlia, well worth adding to your collection. Price, 35c.

Moonbeam. An immense flower borne on excellent stems. Color, clear canary yellow. The plant is a sturdy grower. Blooms very freely and is an excellent keeper when cut.

Price, 50c.

Mrs. George Reed. White deeply tipped pink Edge of petals evenly notched. Good size. Flowers freely.

Price, 25c.

Mrs. Robert Bell. Dec. Deep butter yellow. A good size Dahlia with a desirable color.

Price, $\$ \mathbf{2 . 5 0}$
Mrs. I. Devere Warner. Color, a light lavender purple. The blossoms of this Dahlia are very large and deep. It makes a very vigorous plant and is a very free bloomer.

Price, $\$ 3.00$

Note.-This is the first "Mrs. I. DeVere Warner" dahlia originated and named by the late Judge Marean.

Mrs. Roosevelt. Delicate light pink, shading to soft rose toward the center. An exceptionally large and elegantly formed flower, measuring from 5 to 7 inches across. Greatly admired by all. Large, strong stems. Abundant bloomer. Price, 50c.

Pride of New Haven. Dec. Light butter yellow. In shape it much resembles a large Show Dahlia. It possesses fine stems for cutting.

Price, $\$ 1.50$

Princess Juliana. Pure white, and of good form. This Dahlia is unsurpassed for decorative purposes, having long, strong stems. Of special merit. Price, 50c.

Royal Scarlet. Color is aptly described by its name. Petals are flat and sharply pointed.

Price, 35c.

Salisbury White. Medium sized flower of good form, and suitable for cut flowers.

Price, 25c.

Santa Cruz. Clear canary yellow, tipped carmine. Flowers 6 inches in diameter.

Price, $\$ 1.00$

Sapho. White, slightly shaded pink.

Price, 25c.

The Bashful Giant. This is a Dahlia of the apricot color with golden shadings. It is very large in size.

Price, $\$ 5.00$

Thompsonii. Solid light red, of good form and size and very desirable for cut flowers.

Price, 25c.

Treasure. Pink ground, striped and splashed with carmine. Price, 25c.

Wabash. Color, a beautiful flesh pink. This beautiful flower resembles a Hybrid Show somewhat in appearance. It is a very large flower and in every way attractive.

Price, $\$ \mathbf{2 . 0 0}$

Yellow Le Colosse. Canary yellow. An immense, full flower of the most exquisite shade of canary yellow. Very desirable in very way.

Pricee, 25c.

\section{PEONY-FLOWERED DAHLIAS}

\section{I prepay carriage on all retail bulb orders, accompanied by cash in full, in the United States. This does not apply to Special Offers.}

Caecila. Creamy white; very large. A splendid variety.

Price, 25c.

Dr. Peary. Dark velvety mahogany red, the darkest of all. A very large Dahlia and certainly a beautiful one. Price, 50c.
Glenton. Color, mauve fawn. Of good size and very desirable.

Price, 35c.

H. J. Lovinck. White shaded lilac, very fine form on long stems. A large and beautiful Dahlia. 


\section{PAEONY-FLOWERED DAHLIAS-Continued}

Annie Slocombe. Another new and choice Paeony-flowered Dahlia with a diameter measuring from $7 \frac{1}{2}$ to 8 inches. Its face is entirely of a bright, pleasing canary yellow, but the entire back of the petals is covered with a dull shade of salmon red streaked with the yellow of the face. It is very striking and when held to view one might think it was tipped salmon red, for some of the petals turn at the points, showing the back coloring. It is on long stems, good for cutting. An extra nice variety.

Price, $\$ 1.00$

Great Britain. A lovely shade of lavender pink, rather deeper at base. Bears the appearance of being slightly blotched with white spots. A full, fluffy Paeony with sharply pointe 1 petals, curled about most attractively. A large flower on good, stiff stems. Very desirable.

Price, $\$ 2.00$ Isaquah. Light purple. A very full
flower.

Mannakea. A large Paeony-flowered Dahlia of a beautiful shade of old rose, the tips of the outer petals being shaded to a rich pinkish lavender. The petals are long and. graceful, giving the flower a fluffy appearance. Price, $\$ 3.00$

Miss Adelaide M. Buttle. Pale lemon yellow. Large flowers with long twisting petals.

Price, $\$ 1.00$
Mme. J. Coissard (Duplex.) Very beautiful shade of deep cerise, shading to white in center. Whole flower more or less overspread with white. Good sized flowers and very desirable. Petals are broad and flat.

Price, 50c.

Mosel (Duplex). White shaded to scarlet. Base of petals white, and varying from white to a beautiful scarlet the entire length.

Price, $\mathbf{5 0 c}$.

P. W.. Janssen. Rosy salmon with a shade of yellow; an elegant flower, borne on stout, erect stem. A rich and pleasing shade.

Paul Kruger. Striped red and white. Very unique coloring. $\quad$ Price, 25c.

Pretoria. Medium sized Paeona,slightly yellow at base, main body velvety red of a dark hue. Price, 50c.

Semiramis. Large, pink flowers with open, yellow center. Base of petals around center is yellow, with a broad line of yellow running down the pink petal to the tip. Outside rows of petals all pink except for a tint of yellow at extreme point of petal. A very handsome Paeony. Price, 35c.

South Pole. Pure white. A very nice Paeony-flowered Dahlia. Long stems; good for cutting.

Uncle Sam. A monster Dahlia in size Color orange buff, shading bitter sweet pink at tips. Stems extra long. Price, $\$ 5.00$

\section{SHOW AND FANCY DAHLIAS}

\section{I prepay carriage on all retail bulb orders, accompanied by cash in full, in the United States. This does not apply to Special Offers.}

A. D. Lavoni. Show. Delicate pink. Well-formed flowers with long stems. Very desirable for cutting. This is an old standard Dahlia which every Dahlia grower has retained from its introduction, on account of its exquisitely beautiful color and perfectly rounded ball-shaped flower. One of the freest blooming Dahlias in cultivation. Try a half dozen of these.

Price, 25c.

America. Show. Light slate, with vivid crimson stripes. Often a solid color flower on same stalk. Sometimes the plant produces solid red flowers. Much admired. Price, 20c.

Arabella. Fancy. Sulphur yellow with pink tips. Desirable in every way as a fancy Dahlia.

Price, 25c.

Boundstone. Show. Deep lavender on good stems. Price, 50c.

Cuban Giant. Show. Dark reddish maroon. Flowers of great size, measuring 6 inches across; stands erect on very long stems well above the foliage. The immense number of large, richly hued flowers presents a magnificent appearance. Price, 25c.
Crown Prince. Show. Buff, deep rich color. Good formed blossoms. A very desirable ball-shaped flower. $\quad$ Price, 25c.

Dreer's White. Show. A clear snow white. This beautiful show Dahlia is very large, finely formed and beautifully quilled. It flowers very freely, and is by far one of the best pure white show Dahlias. Price, 50c.

E. F. Hill. Show. Deep lavender pink. A perfectly quilled Dahlia of good size and form on long stems.

Price, $\$ 1.00$

Elsie Burgess. Show. The color is a delicate white ground tipped and suffused with a beautiful lavender and faint light pink. The stems are straight and stiff. It is a free-blooming Dahlia and very desirable for cut flower purposes. $\quad$ Price, 25c.

Ethel Maule. Show. Pure glistening white. One of the finest in its class. Large and beautiful. Faint tint of lavender on tips of petals in center. Price, 25c. Fascination. Show. White, suffused lavender pink. A beautiful, free blooming Dahlia.
Price, 20c. 


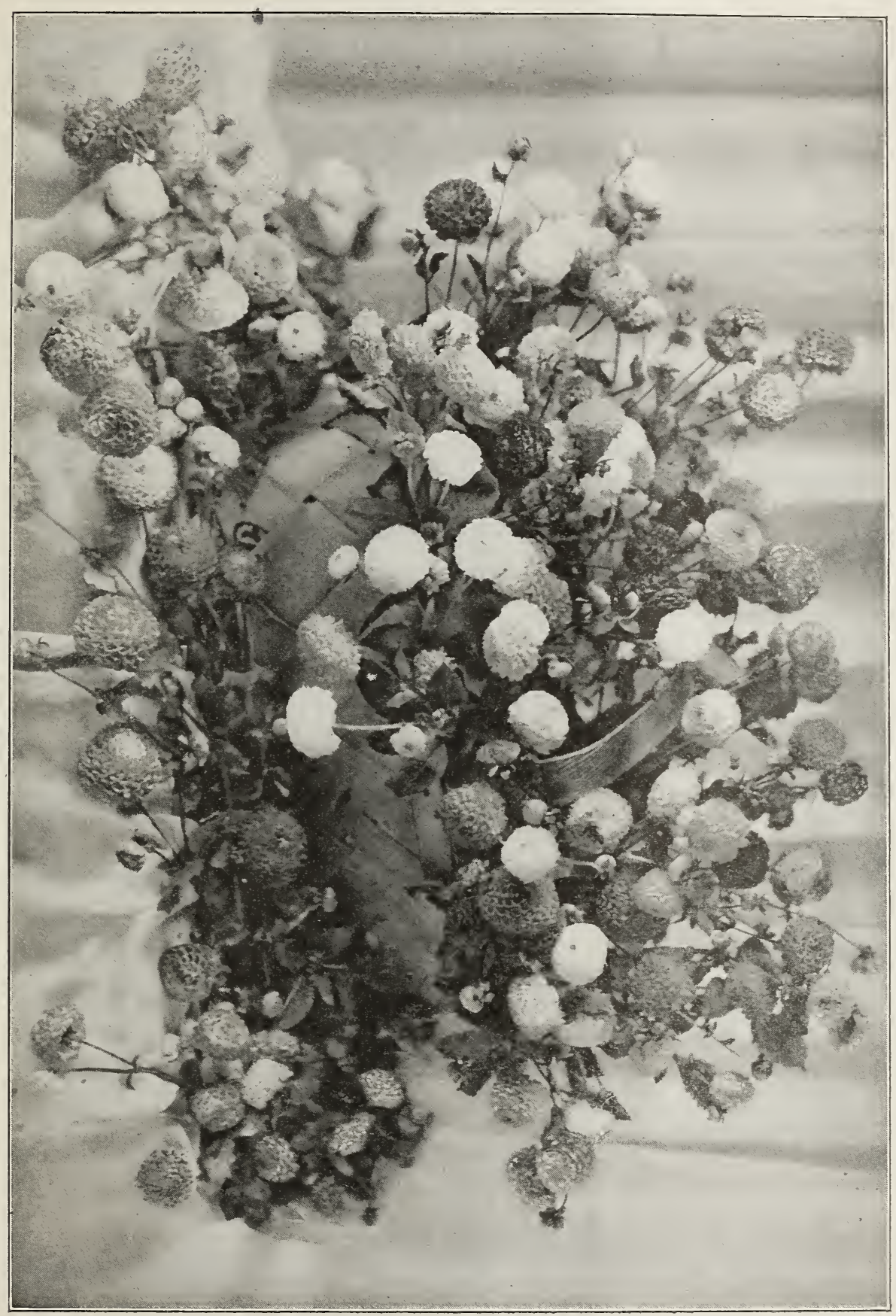




\section{SHOW AND FANCY DAHLIAS-Continued}

General Miles. Light violet striped and splashed with purplish magenta. An enormous flower borne on long, stout stems. The very best variegated show Dahlia in existence.

Price, $\$ \mathbf{2 . 0 0}$

Gloria De Lyon. Show. White. A very fine flowering Dahlia. Price, 25c.

Grand Duke Alexis. Show. This is one of the most delicately beautiful, show Dahlias. The color is pure white, softly bordered with lavender. The flowers are very large and decidedly pleasing in effect, being especially distinguished for their dainty coloring.

Price, 25c.

Henri Depresie. A very full and solid show Dahlia of a very clear shade of red, slightly orange red. Decidedly erect on heavy, strong stems.

Price, 50c.

John Thorp. Show. Pink, slightly tinted white at base. A very striking combination of colors and in every way desirable. Price, 25c.

Keystone. Fancy. Lilac, with pink shading. Regular stripes of glowing crimson on each petal. A unique combination of color, very bold and striking. Blooms profusely.

Price, 50c.

Les Amours de Madame. Fancy. Show. A very attractive lavender rose pink of fine form. Nicely rounded Dahlia of good size. The petals are marked and spotted somewhat with a much deeper shade, almost red. Very desirable; on good stems. Slightly variegated.

Price, 25c.

Mad. M. Anagnostaki. Fancy. A sensational wonder. Remarkable for its dainty blending of colors, being snowy white, delightfully shading to a beautiful rose pink.

Price, 50c.

Mme. Alf. Moreau. Fancy Show. Base of petals white, edges and tips lavender. Good size and showy.

Price, 35c.

M. Con Varin. Dark purple, some of the petals having tips touched with white. Very pleasing.

Price, 20c.

Mrs. Kendal. Fancy show. White heavily edged purple. A distinct flower of unusual beauty.

Price, 25c.

Mrs. Saunders. Fancy. A beautiful lemon yellow with white tips. Good size with a very rare combination of coloring.

Price, 25c.

Puritan. Fancy show. White, striped maroon. Medium size and one of the handsomest Show Dahlias for solid color bouquets.

Price, 25c.
Queen Victoria. Show. Lemon yellow. Flowers unusually full and round. Strong stems and fine for cutting. Price, 15c.

Red Fire. A very good light red Show Dahlia. Well worth owning. Price, 25c.

Rose. Show. Aptly named. Remarkable resemblance to a Rose. Of a typical rose shade. Base of inner rows of petals much deeper reddish rose than outer petais which are somewhat paler. Price, 35c.

Striped Banner. Tips of petals are white, jagging down into the base of the petal, which is royal red or dark scarlet. A novel and striking blossom.

Price, 25c.

Surpasse Colosse. Show. Color, scarlet carmine, flowers large, with large quilled petals.

Price, 35c.

Sunburst. Show. Color, salmon. Fine form and a beautiful shade. Price, 25c.

Susan. Show. A beautiful, delicate, soft shell pink, splendid form, early and free flowering, long stems. Splendid for cutting.

Price, 25c.

Tillamook. Show. Similar in shape to "Dreer's White." The whole blossom is very, very pale pink. Each petal is folded over neatly, making a beautiful flower.

Price, 25c.

Triomphe de Lorraine. Fancy Show. Light brickish red. Good full flower and compact. Base of the many small petals is blended into a reddish salmon lighter than tips. Good stems. Price, 25c.

Vivian. Show. Large and of beautiful colorings. Center of blossom dark magenta, the inside of the petal being much lighter cerise or Jacqueminot. A large and excellent Dahlia.

Price, 25c.

W. H. Williams. Show. Rich scarlet. A large, noble flower of compact form. Florets very evenly and tightly formed, and a free bloomer.

Price, 25c.

White Swan. Show. Pure white. Very nice specimen.

Price, 25c.

W. W. Rawson. Show. This popular novelty has been.the admiration of all wherever shown the past season. The massive perfect flowers, often measuring 6 inches across, are borne on stiff.stems about 15 inches long. The entire flower is absolutely perfect in outline and formation. The color is pure white, overlaid with amethyst blue.

Price, 25c.

\section{DAHLIA STAKES}

As many of my customers make inquiries of me as to where they may obtain strong Dahlia stakes, I have arranged to furnish a good, strong, Oak Stake, 11/4 inches square, and 6 feet long, in the rough, just as they come from the mill, at 12c. each, F. O. B. Westerly. 


\section{ORDER SHEET}

\section{George L. Stillman, Dahlia Specialist} WESTERLY, RHODE ISLANE

Date.

Amount inclosed

\section{Your Name.}

¿ $P . O$.

State

Shall I substitute for any that are sold oun

About what date do you want them?...

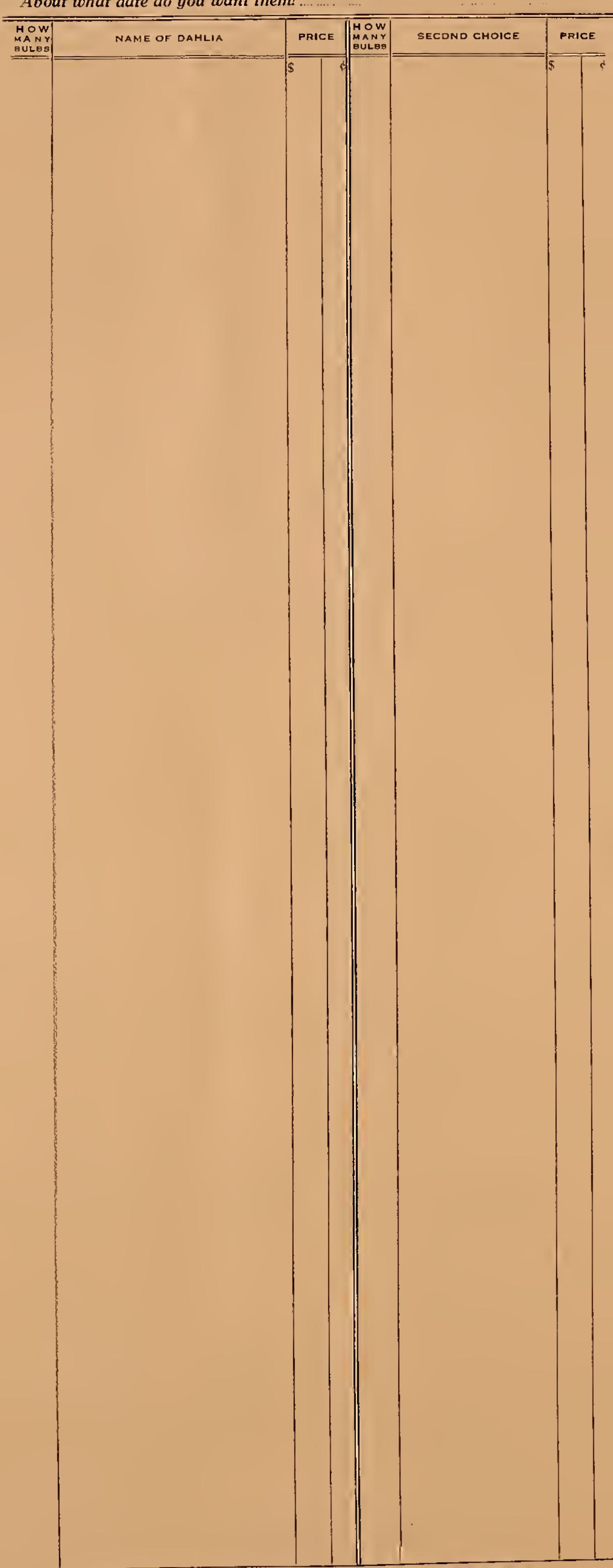

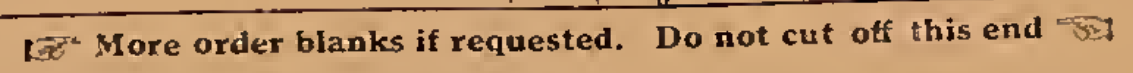





\section{SINGLE DAHLIAS}

Blush Century. Clear white, slightly overcast with delicate shade of pink.

Price, 25c.

Blushing Maiden. This is a Dahlia of beautiful shadings. The florets are a light maroon mingled with a light carmine, and has a pure white stripe through the center of petals. Very attractive. Price, 25c.

Coquette. Deep cerise pink. sometimes edged with a deeper shade. Quite large.

Price, 25c.

Dauntless. About one-fourth of petals at base yellow, remainder of petals rose pink, edged, dotted and streaked with magenta. Some of the petals have several stripes of the magenta through them, while others have somewhat less number of streaks.

Price, 25c.

Falcon. Reddish purple, with white disc around the center; a large flower in which the color contrast is both striking and beautiful.

Price, 2jc.

G. H. Longman. Lavender pink. Petals broad and flat. Medium sized flowers; long stems; very desirable for cut flowers.

Price, 25c.

Lady Mildred. Pure white. Now and then shows a very faint pink tinge. Flowers large and perfect. Extremely graceful, and one of the most desirable white single Dahlias.

Price, 25c.

La Favorite. Dark rose, striped with rich purple and white. An exquisitely dainty flower. Large and blossoms freely.

Price, 25c.
Mabel C. A single Dahlia of unusual merit. The color is a lavender pink, with an amethyst shading at base of petals. Flowers large and graceful. Price, 25c.

Margaret Perkins. One of the most beautiful varieties of recent introduction. The flowers are very large, have rather pointed petals, are wide, but not overlapping, and are borne on very long, stiff stems. The color is pure white, with about onehalf of each petal tipped light pink; first flower being ti sed cerise pink, and, like "Twentieth Century," of which it is a seedling, growing steadily lighter as the season advances, becoming a clear, soft pink later.

Price, 25c.

Madame X. Deep velvety carmine, occasionally blended and shaded lighter.

Price, 25c.

Miss Emma. Dark salmon yellow with light center. Very large and attractive.

Price, $15 c$.

Mrs. Evans. White, flushed pink, finely striped and spotted crimson. Price, 25c.

Sensation. Single. Vivid vermilion, heavily tipped white. An early and profuse bloomer. Very popular. Price, 15c.

Twentieth Century. Pure white at base and tip, with center of petals a beautiful rose pink. A very popular Dahlia and worthy of the highest praise. Flowers freely. Price, 25c.

\section{TESTIMONIALS}

Feb. 6, 1924-A gentleman in Pa. writes: "I am enclosing N. Y. draft for two packages N. Y. Group dahlia seed. The seeds you shipped me last spring gave unusual satisfaction. From the package I secured 148 plants, all of which bloomed and provided me with a wealth of blossoms. My success has enthused many of my friends who plan to try the same method this year."

Sept. 5, 1924-A gentleman in Conn. writes: "The dahlia seed from the Cobbler I got from you turned out fine. I got lots of nice flowers and large size; some of them over 7 inches and no two alike. My friends think they are just grand."
Sept. 2, 1924-A lady in Conn. wrote me thus: "The plants which I grew from seed purchased from you this spring are just beginning to bloom and are very pretty. I picked one this morning, a beautiful bufí shade which. measured 7 inches across. They are all full of buds."

May 6, 1924-A lady in Ohio wrote me of her success as follows: "You will be pleased to hear that at the Show last fall I won the blue ribbon for best collection of seedlings, entirely from your seed. I also won blue ribbon on both collections and 12 of a kind of pompons, a part of the pompons were from another grower."

\section{CORD FOR TYING DAHLIAS}

In various lengths, but as good as new for this purpose. A very limited supply, $8 \mathrm{lbs}$. for $\$ 1.50, F$. O. B. Westerly. Your postmaster can tell you the cost of $8 \mathrm{lbs}$. by mail to your town. Order now and be sure to have it in time. It can be used for many other purposes. 


\section{POMPON DAHLIAS}

I prepay carriage on all retail bulb orders, accompanied by cash in full, in the United States. This does not apply to Special Offers.

Admiral Dott. Pink, with lavender tinge. Very free bloomer. Round, perfect blossoms.

Price, 20c.

Ariel. Buff tinted orange. Very desirable.

Price, 20c.

Belle of Springfield. Very pretty shade of light red. The smallest Dahlia known. Very round and regularly formed blossoms of diminutive size.

Price, 50c.

Bobby. Very finely formed flower of an attractive shade of plum color. An extra good Pompon.

Price, 25c.

Brunette. The color of this little Dahlia is a very bright. carmine red; one of the very richest colored Pompons. Occasionally it comes with a quantity of white in the center. The quills are perfect and the whole blossom is attractive and a most desirable variety.

Price, 50c.

Darkness. Deep, solid maroon, nearly black.

Price, 15c.

Eunice. Lavender with white shading. A very desirable color.

Price, 25c.

Fascination. Pink and lavender, sometimes blotched white.

Price, 25c.

Kleindomiter. Clear, delicate buff color, shading lighter around outside edge of blossom.

Price, 50c.

Klein Gretchen. White, shaded 'crimson, eaving the blossom principally crimson. 1Base of petals white, while all the rest of petal is crimson. Striking and beautiful.

Price, 25c.

Leuchstern. Orange, richly shading to deep orange red. Very fine.

Price, 25c.
Little Herman. Color, dark red, while each petal is heavily tipped white. A very showy little pompon. Price, 50c.

Little Jennie. Primrose yellow. A beautiful flower of diminutive size; free bloomer.

Price, 25c.

Little Mary. About the size of Belle of Springfield but it is a velvety dark maroon, about the shade of Darkest of All.

Price, 50c.

Madeline. Pale primrose, edged with rose purple. Variegated. Price, 25c.

Marguerite. Deep lilac. Blooms freely. On good stems for cutting. Price, 25c.

Mary Clift. Light maroon. A very compact flower on good stems. Price, 15c.

Santoy. White, very heavily tipped carmine.

Price, 25c.

Snow Clad. Pure white. This dainty little white flower should be seen to be appreciated. It is very prolific, producing a great abundance of flowers. $\quad$ Price, 25c.

Sunset. Color, deep orange. A small perfect flower and one of the most desirable Dahlias in the whole Pompon family.

Price, 50c.

Tulla. Wine crimson. A very free bloomer and exceedingly beautiful. Price, 25c.

Zoe. Base of petals and edges clear yellow. Tips white. This is a very attractive. Dahlia and well worth having. Sometimes blossoms come all yellow.

Price, 25c.

\section{COLLARETTE DAHLIAS}

\section{1 prepay carriage on all retail bulb orders, accompanied by cash in full, in the} United States. This does not apply to Special Offers.

A. Mammene. Nice dark red Collarette Dahlia with white collar.

Price, 25c.

La Fusse. Petals twisted to give the flower the appearance of a single Cactus; color deep ox-blood red, the collar being of same shade, marked with white.

Price, 15c.

Maurice Rivoire. A medium flower with broad petals of rich maroon, with deeper stripe down the center, and a pure white fringed collar.

Price, 15c.

Meteor. Postively the best of its color; ground color, brilliant scarlet, penciled, spotted and striped with rose color. Collar white. A flower of fine form. Price, 25c.

Prince Carilie de Rohan. A pleasing pink touched and blended with bluish lavender. Tiny collar of same shading. Very good size, attractive and on good stems.

Price, 50c.

Souvenir de Chabanne. Ground color, lemon yellow, with coral red markings; collar petals very abundant and long, lemon yellow, tipped white.

Price, 25c.

Swallow. Collarette. Pure white with a collar of white. Fine long stems.

Price, $\$ 2.00$ 


\section{PLEASE NOTICE}

Every Dahlia offered in this catalog is described to the best of my ability as they are while growing in my fields without any disbudding; and every statement as to size is positively correct as they grow for me with no extra care. If disbudding with proper care is resorted to they will exceed sizes stated. If a purchaser does not grow them to sizes stated the fault is not mine. It may be the weather, the kind of soil, lack of water, and a dozen other things. One year's trial is not sufficient to try out a new variety. Experiments in your own garden are the best education.

\section{PRICES}

Orders received prior to Jan. 1st for shipment the following season will be subject to prices quoted in the new catalogue even though they have becn reduced from the last issue.

All shipments to Canada after being delivered to the Express Company or the U. S. mail are at purchaser's risk as to delays or loss.

\section{SPECIAL OFFERS}

\section{Parcel Post or Express paid by the purchaser. See table below.}

For the benefit of those who are not familiar with the names, colors, and characteristics of the Dahlia, and wish to have the selection made for them, I make the following collections at a special low price to even up stock. They consist of an assortment of classes and colors and the entire selection must be left to me.

No. 1 COLLECTION, twelve named varieties, several classes, my own personal selection, no two alike, and each one labeled ..............

No. 2 COLLECTION contains twelve extra fine, high-priced varieties, my own personal selection, no two alike, and each one labeled. This col-

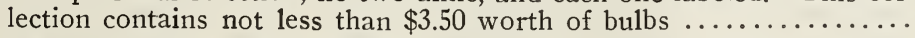

No. 3 COLLECTION contains twelve varieties, or more, of extra nice assorted bulbs very carefully selected, no two alike, all labeled. The Dahlias in this collection amount to not less than $\$ 7.00$ worth ......

No. 4 COLLECTION contains twenty bulbs, without labels, that have become mixed in handling. They are all good varieties, but labels have accidently become detached. The supply for this collection is limited.

Price while they last. This collection ............... Postpaid

\section{Be Sure to Read This}

It has been thoroughly demonstrated that nearly all small shipments of bulbs can be sent by mail and reach their destination quicker than by express.

NOTICE! The postage or express on all special offers must in all cases be paid by purchaser, and if by mail, postage must be sent with the order or pay C. O. D. charges to destination, which often amounts to more than the postage.

To ascertain the amount of postage" to send.

No. 1, 2 and 3 Collections weigh four pounds or less.

Your postmaster can teli you the cost of any number of pounds from Westerly, R. I. to your post office. Or you can use the following table. If you send more money than is used in postage, the surplus will be returned.

\section{TABLE}

1st \& $2 \mathrm{~d}$ Zone $3 \mathrm{~d}$ Zone

1 lb. 5c. 1 lb. $6 \mathrm{c}$.

2 lbs. 6c. 2 lbs. $8 \mathrm{c}$.

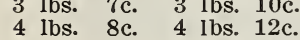

5 lbs. 9 c. 5 lbs. $14 c$.

6 lbs. 10c. 6 lbs. $16 \mathrm{c}$.

$\begin{array}{ll} & 4 \text { th Zone } \\ 1 & \text { lb. } 7 \mathrm{c} . \\ 2 & \text { lbs. } 11 \mathrm{c} . \\ 3 & \text { lbs. } 15 \mathrm{c} . \\ 4 & \text { lbs. } 19 \mathrm{c} . \\ 5 & \text { lbs. } 23 \mathrm{c} . \\ 6 & \text { lbs. } 27 \mathrm{c} .\end{array}$

5 th Zone

$1 \mathrm{lb}$. 8c.

2 lbs. 14c.

3 lbs. $20 \mathrm{c}$.

4 lbs. $26 \mathrm{c}$.
5 lbs. $32 \mathrm{c}$.

5
6
6 th Zone

1 lb. $9 \mathrm{c}$.

2 lbs. $17 \mathrm{c}$.

3 Ibs. $25 \mathrm{c}$.

4 lbs. 33c.

5 lbs. $41 \mathrm{c}$.

6 lbs. $49 \mathrm{c}$.
7 th Zone

1 lb. 11c.

2 lbs. 21c.

3 lbs. 31c.

4 lbs. 41c.

5 Ibs. $51 \mathrm{c}$.

6 lbs. $61 \mathrm{c}$. 8th Zone

1 Ib. $12 \mathrm{c}$.

2 lbs. $24 \mathrm{c}$.

3 lbs. $36 \mathrm{c}$.

4 lbs. $48 \mathrm{c}$.

5 lbs. 60c.

6 lbs. $72 \mathrm{c}$. 


\section{SEED FIELD CORN}

During the last few years I have taken great pride in producing the best corn for family use that can be grown. I think I have now four varieties that contain all the desirable features that any person could wish for family use. One for corn meal and three for green corn. Illustrations and prices for selected seed follow.

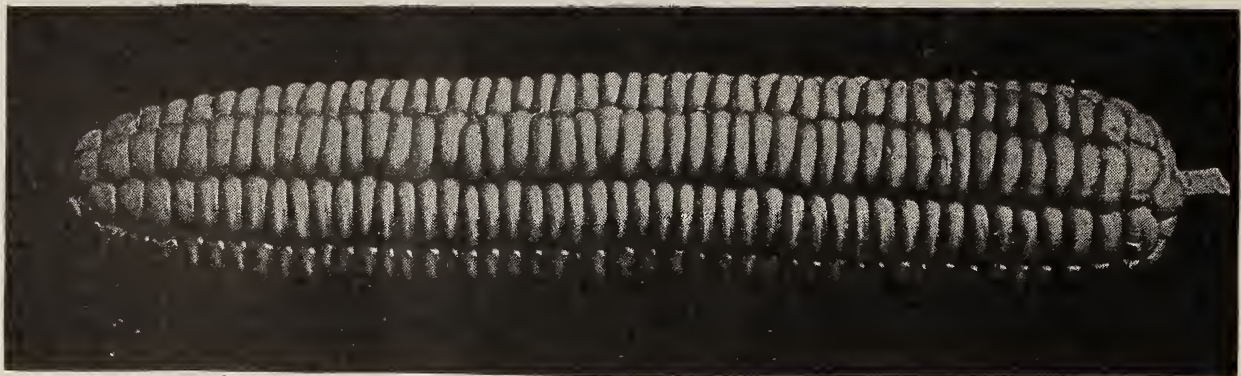

\section{STILLMAN'S SPECIAL RHODE ISLAND DOUBLE CAP CORN}

Outer end entirely capped. Butt nearly capped. The best white northern corn grown. The ears are large, butt stems are exceedingly small. The ears are easily husked and broken off. It yields two and three ears to the stalk. The kernels are large and in straight rows. It makes the sweetest and best table meal. The kind that makes the best R. I. Johnny-Cakes. Always get the Stillman strain.

30c. pt.

$\$ 3.008$ qts. 50c. qt.

$\$ 5$. half bu.
$\$ 1.50$ four qts.

\section{CORN MEAL}

Made from Stillman's Special Rhode Island Double Cap Corn. It's the sweetest and best meal on the market. Ground in an old-fashioned stone "Grist Mill." Fresh every week. Price, 10 lbs. $\$ 1.25$, postuaid in 1 st and $2 \mathrm{~d}$ Zone.

\section{STILLMAN'S EXTRA EARLY GIANT SWEET CORN}

matures the earliest and has the largest ears of any extra early sweet corn. Nothing like it for the earliest crop.

$\square$ Selected Seed, 75c. per 'pint, 40c. per 1-2 pint.

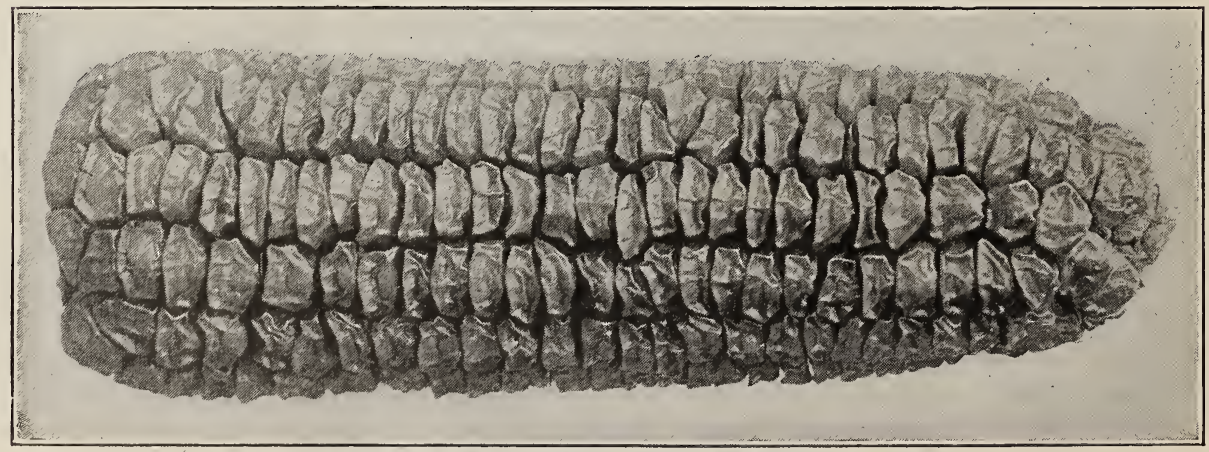

Stillman's Extra Early Giant Corn. Ears 6 to 7 inches 


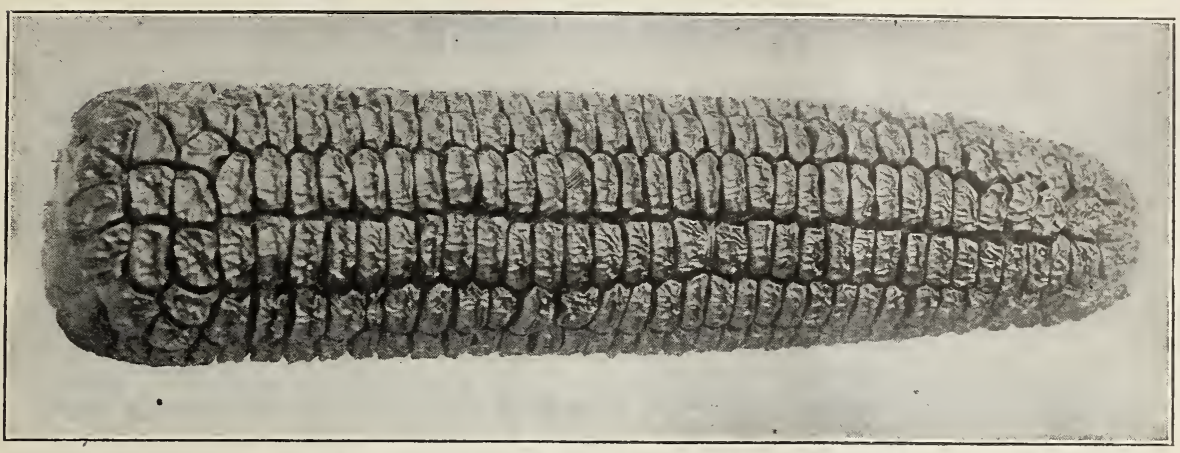

The New Sweet Orange Corn. Ears 7 to 8 inches

\section{THE NEW SWEET ORANGE CORN}

Much larger than the Golden Bantam. The sweetest early green corn grown. Grows a medium height and ears profusely.

Selected Seed, 75c. perquart, 40 c. per pint

\section{MT. SHASTA SWEET CORN}

The largest and sweetest green corn in the world. This mamnoth new corn is in a class by itself. Nothing can beat it for sweetness and its mammoth size.

June 6, 1923. A gentleman in South Carolina wrote me thus: "Please ship me two pounds of seed of your Mt. Shasta corn. I noticed your claim that your Mt. Shasta was the largest and sweetest corn, and I tried a small quantity last year, really thinking you were covering too much territory in your claim. Have decided you knew whereof you spoke. After eating your corn we no longer care for the ordinary sweet corn."

Selected Seed, 75c. per pint, 40c. per 1-2 pint

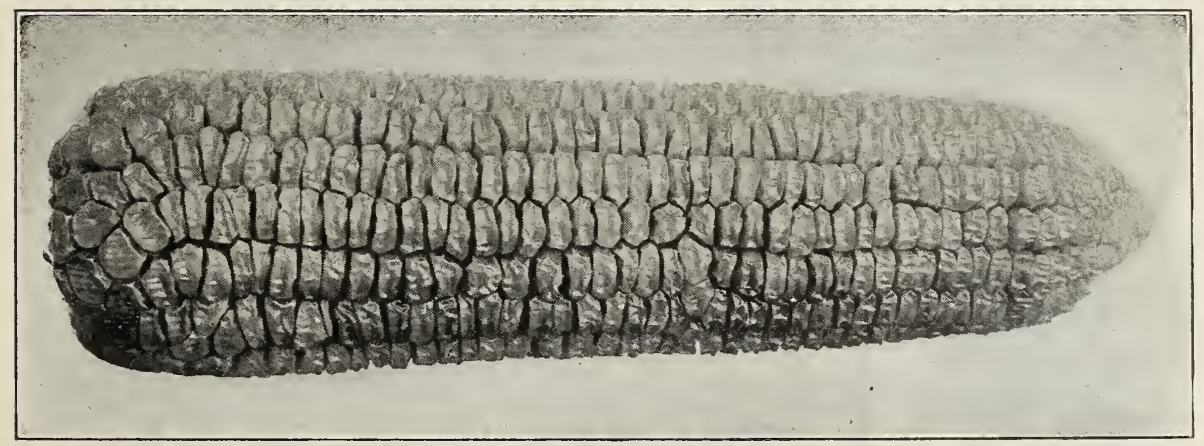

.. Shasta Sweet Corn. Ears 9 to 11 inches

\section{WORM KILLER}

\section{THE WILLIAMS WORM KILLER}

I have taken the agency for this new device for killing the borer inside the Dahlia stalks. It is a handy little tool and works to perfection without the slightest injury to the plants. 


\title{
DAHLIA SEED
}

IMPORTANT-It is very important that you understand that every plant you get from seed is an entirely new variety and may be even better than the flower it is taken from. So please do not call any dahlia obtained from seed by any name that is already given to any dahlia as it has no connection with any other.

I do not save seed from poor, insignificant flowers. The wonderful success my customers have with my seed is ample proof that it is far superior to any on the market.

\section{DIRECTIONS FOR PLANTING}

In the latitude of New York City seed should be sown about March 15th to April 1st. Flats or boxes about 3 or 4 inches deep are best. Cover the seed about 1 inch deep and keep in a warm place until the plants are all above ground. Then they can be moved to a cooler place. They should be kept in the sun to avoid growing too slender. Transplant in the open when weather is free from frost, about 15 inches apart. Discard any undesirable ones as soon as they bloom, thus giving the others more space.

Prices of seed in large packages as follows:

THE FAMOUS RHODE ISLAND GROUP $\ldots \ldots \ldots \ldots \ldots \ldots 25.00$

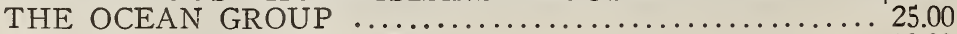

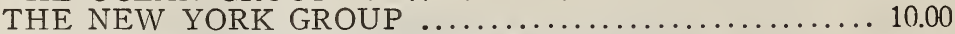

SPECIAL MIXTURE NEW SEEDLINGS $\ldots \ldots \ldots \ldots \ldots \ldots \ldots . \ldots \ldots$

THE FIVE WORLD WINNERS $\ldots \ldots \ldots \ldots \ldots \ldots \ldots \ldots \ldots \ldots, 5.00$

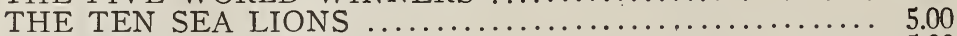

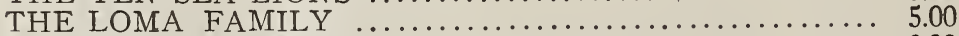

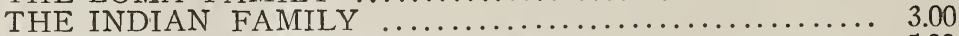

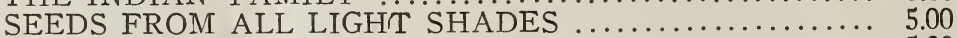

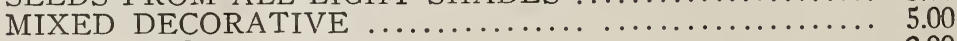

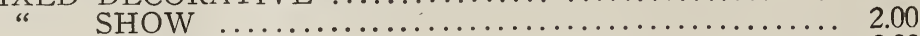

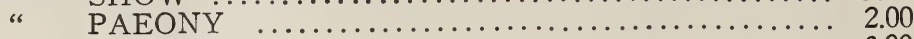

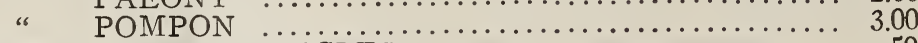

SEED FROM ALL SINGLES $\ldots \ldots \ldots \ldots \ldots \ldots \ldots \ldots \ldots \ldots, .50$

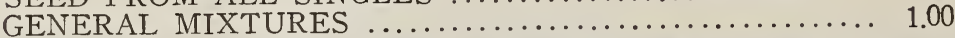

To meet the wants of some of my customers I have kept the following popular varieties of seed separate. Prices as follows:

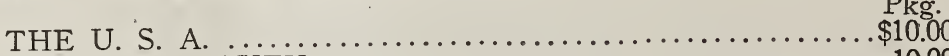

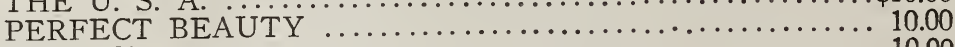

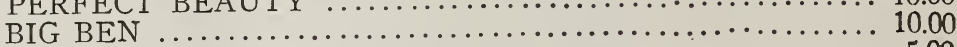

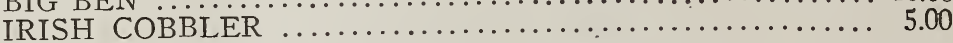

Orders for bulbs will be booked for Spring delivery any time in the year.

Full Cultural directions on cach package.

NOTE-Have you read instructions carefully about ordering and the best way to send money? Order by name as well as by number.

Address all communications to

\section{GEORGE L. STILLMAN, Dahlia Specialist}

\author{
WESTERLY, RHODE ISLAND
}

\section{SAMPLE DAHLIA BLOOMS}

For the purpose of showing samples of my dahlias to people who cannot visit my fields I will label and ship a box of 35 to 50 blooms prepaid in the Ist, 2 nd, or $3 \mathrm{rd}$ zones for $\$ 5.00$. If an order is received from these to the amount of $\$ 25.00, \$ 2.50$ will be deducted from it; if an order to the amount of $\$ 50.00, \$ 5.00$ will be deducted. 


\section{TESTIMONIALS}

Oct. 16, 1924-A gentleman in Georgia wrote me thus regarding his dahlia seed: "Last spring I planted a package of your dahlia seed from new seedlings and have had a yard full of wonderful flowers all the fall. While all of the flowers are large and fine, and have been admired by visitors almost daily, I have secured six or seven that, if they hold true to the original seedlings, I consider are more than worth the $\$ 10.00$ package of seed."

Oct. 18, 1924-A lady in Tenn.-Va. wrote me: "My collection was worth more than you charged for it. Please mail me a catalogue."

Feb. 21, 1924-A lady in Conn. writes: "I wish to tell you that the bulbs I have had from you have been wonderful and believe me, it is lack of money, not desire, that prevents me from ordering more of your beautiful flowers."

April, 1924-A gentleman in Connecticut writes me thus: "Had a package of seed from you several years ago, and did mighty well with them. Took all blue ribbons at locai show last year with seedlings raised from your seed. I have no trouble making them bloom first year from seed sown outdoors in the open ground after Apri] 25th."

March 20, 1924-A lady in Maine wrote me: "Late in the season last year a friend told me of your special offer No. 4. I sent to you at once and planted them, and all came up beautifully. It certainly was the nicest collection of flowers I ever had."

March 11, 1924-A lady in Ill. wrote me this: "We raised some dahlias from your bulbs two years when we lived in Mass. We never enjoyed anything as we did those dahlias. They were wonderful; many people stopped and asked about them."

March 8, 1924-A gentleman in Maine writes me about corn as follows: "I have seed enough of the Sweet Orange corn, so will ask you to send the Extra Early Giant. Sorry not to get the Mt. Shasta, as it is by far the sweetest corn I have ever had."

Jan. 5, 1924-A gentleman in Texas writes thus: "My son bought the Indian Family dahlia seed from you two years ago, and I never saw such blooms. Some were eight and ten inches across."

Oct. 7, 1924-A lady from New York wrote me thus: "It may interest you to know that at the recent dahlia show of the
Garden Club I entered 12 of your dahlias and took 10 prizes. So I thought I did well. Forest Loma got a first and a root I gave to a friend got second."

Oct. 6, 1924-A lady in Ohio wrote: "Last spring I ordered one of your $\$ 1.00$ collections No. 4. They all.grew and while I do not care for some of them, I have one that in every respect tallies with your description of your fifty dollar dahlia, "Our Country,' Do you suppose it could be 'Our Country'? Whether it is or not, I thank you for the pleasure it has given me."

April 8, 1924-A gentleman in Virginia writes: "Last year I purchased from you a package of dahlia seed from which I raised a number of plants. In raising dahlias I have never had as much pleasure from anything as I did from these seeds. We had some beautiful flowers measuring from 8 to 9 inches across."

\section{Sentenced to Death}

In a sanitary and humane manner, that's the way of the

\section{"PEERLESS"}

\section{Automatic Mouse and Rat Trap}

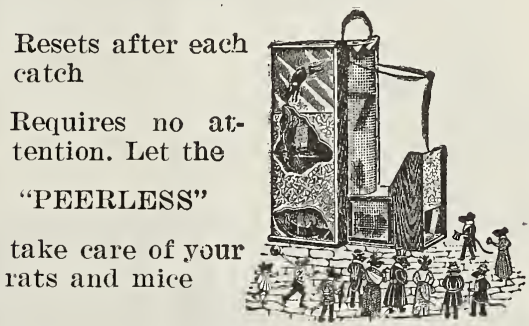

Mouse trap $\$ 3.00$. Rat trap $\$ 8.50$. No. 2 Mouse trap $\$ 2.00$.

I can personally vouch for this trap as being the greatest mouse exterminator in existence. Sent by express upon receipt of price.

Geo. L. Stillman, Westerly, Rhode Island 
May 15, 1924-A gentleman in Porto Rico says: "I ordered a package of seed Jan. 30th and planted them immediately, and raised 75 plants. The first bloomed by April 15. All are very interesting. I shall want some more this fall.

Oct. 6, 1924-A gentleman from Ohis Ivrites: "It is with my greatest of pleasure that I can look with pride at the dahlias I am growing under adverse conditions. In the month of September they held a flower show in this city. Ont of 8 entries I received 5 firsts and one second prize. The Millionaire and King of Shows were wonderful. I received your Special Offer No. 4 and out of that I received a blue ribbon. The dahlias I received from you are beyond my expectations."

Dec. 29, 1923-A gentleman in Mass. writes: "I raised 277 plants from the two packages of seed and after pulling out a lot I have over three barrels of bulbs that are worth trying again."

Sept. 1, 1924-A lady in Ohio says: "We are experiencing the worst drought we have had for many years. But notwithstanding the drought our U. S. A. has been covered with flowers. It surely is a splendid all around variety."

Feb. 1, 1924-A lady in Utah wrote a very interesting letter about seed-condensed as follows: "I had about 70 nice plants and they were a riot of color all summer. I had a beautiful pure white decorative which measured 8 inches across and a lavender decorative which had 27 perfect blossoms on it at once beside the many half-open buds; also a brilliant carmine red which was a deep, heavy flower; and also a very large pink. They are wonderful."

April 15, 1924-A lady in West Virginia writes as follows: "Your dahlia bulbs received in good shape today, and I don't know how to express my thanks to you for your kindness. They are all nice and sound and I see no reason for not having blossoms if properly cared for. Everyone says you are very kind and good. I think you will always prosper as some have already said to me that they liked to buy from anyone like you."

May 5, 1924 A gentleman in Mass. wrote me thus: "On Jan. 31st I sent to you for some of your dahlia seed. They were planted, and I now have just a hundred very thrifty plants."

Oct. 4, 1924-A gentleman on Long Island wrote me: "Last year at the Show I bought a package of your seeds for $\$ 1.00$. I had very good luck with them-some measured 6 3-4 inches across."

For lack of space I regret that I am obliged to omit a great many worthy testimonials which ought to appear on these pages.

\section{THE LADIES NEW DAHLIA SNIPS}

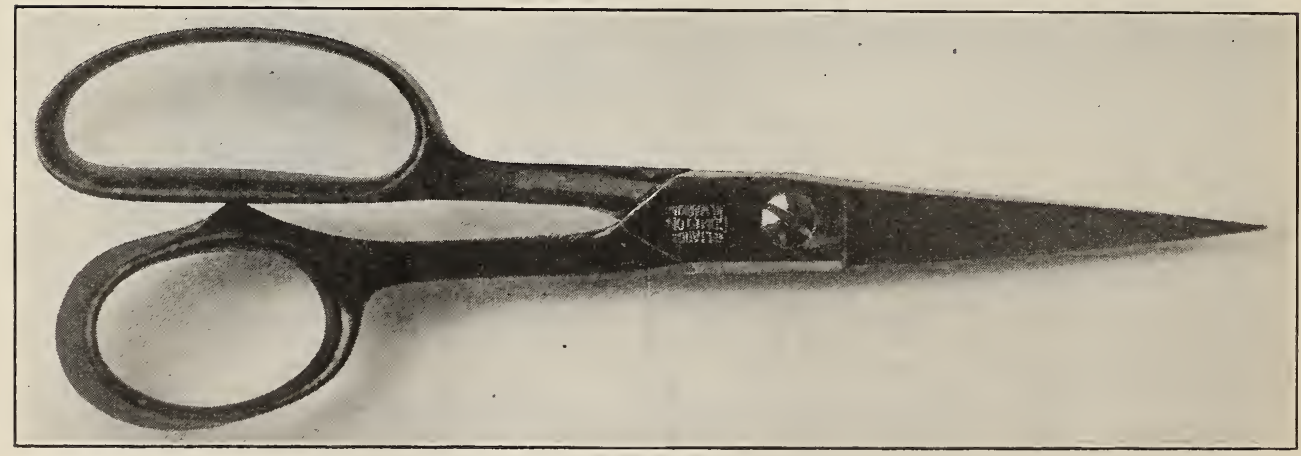

These new snips are meeting with a large demand. Especially used for disbudding, pruning, and cutting flowers. Being 8 inches long they have proven very useful for many purposes in the household and greenhouse. Sent postpaid in the United States for $\$ 2.00$. 


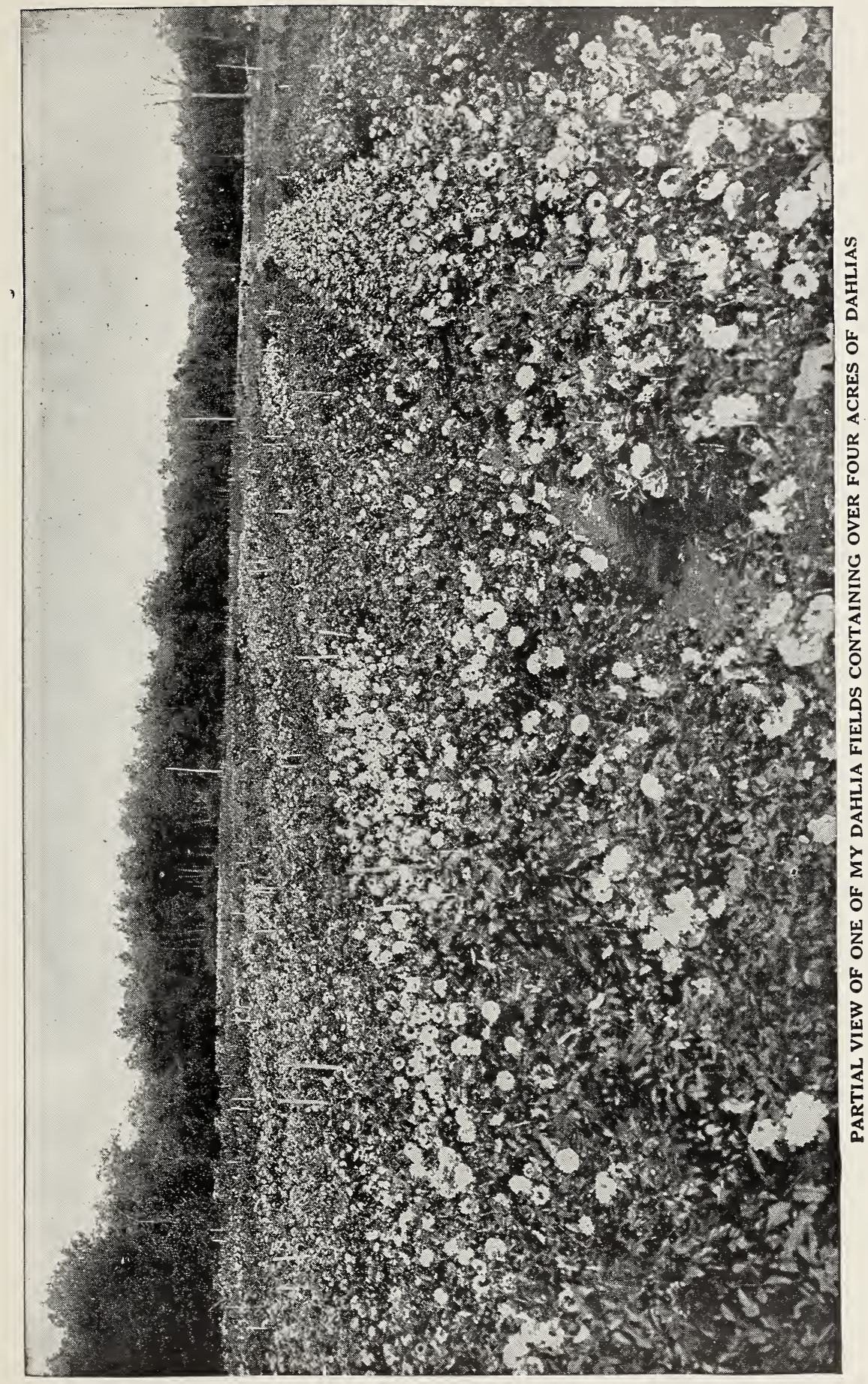




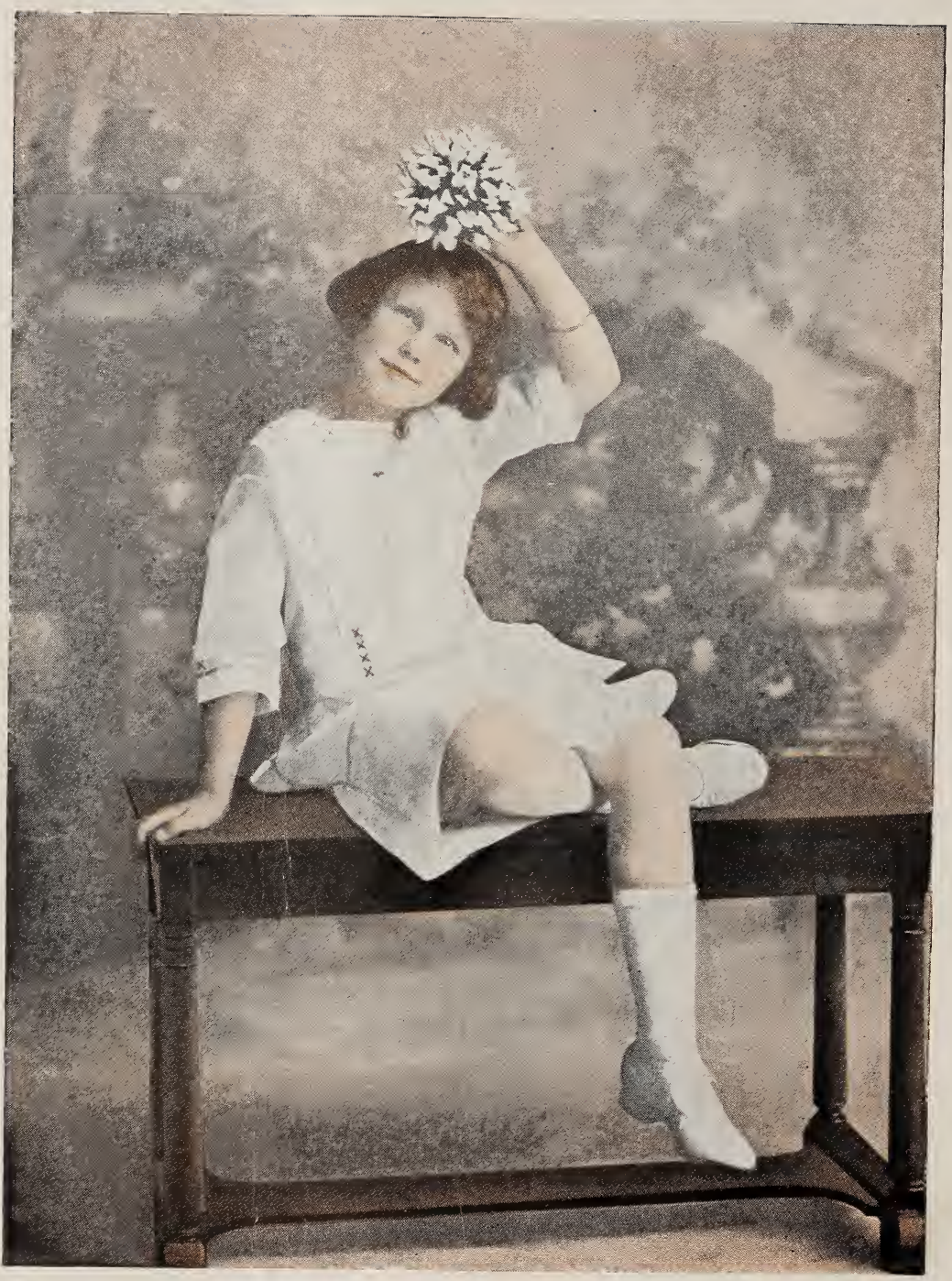

